\title{
Simple and Precision Approach to Polythioimidocarbonates and Hybrid Block Copolymer Derivatives
}

\author{
Tao Lai, $\uparrow$ Pengfei Zhang, $\dagger$ Junpeng Zhao, $\dagger^{*} *$ and Guangzhao Zhang $\dagger$
}

$\dagger$ Faculty of Materials Science and Engineering, South China University of Technology, Guangzhou 510640, China

†Guangdong Provincial Key Laboratory of Luminescence from Molecular Aggregates (South China University of Technology), Guangzhou 510640, China

\section{Table of Contents}

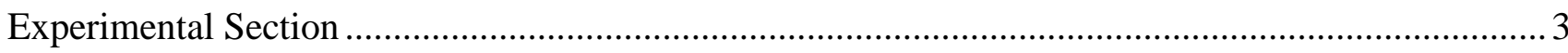

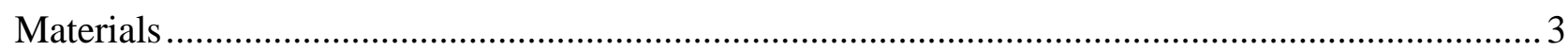

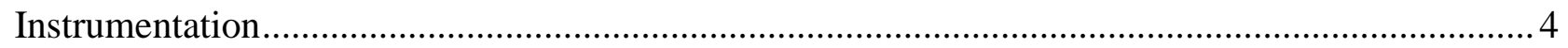

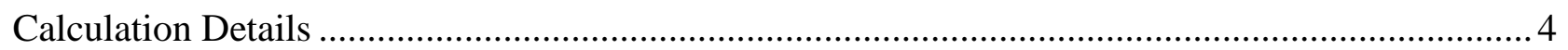

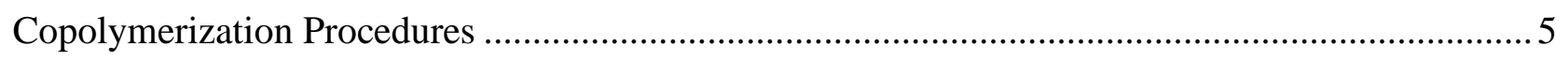

Copolymerization of Isothiocyanates and Epoxides (except EO) …............................................5

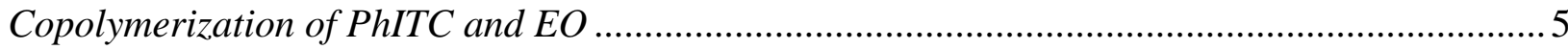

One-Pot Block Copolymerization of PhITC/PO and PO: Copolymerization-First Order ............. 6

One-Pot Block Copolymerization of PhITC/PO and PO: Homopolymerization-First Order ........ 7

One-Step Block Terpolymerization of PA/PO and PhITC/PO .............................................. 7

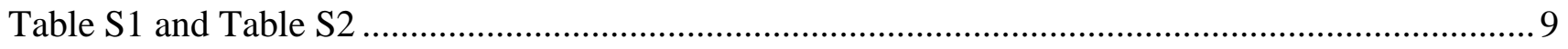

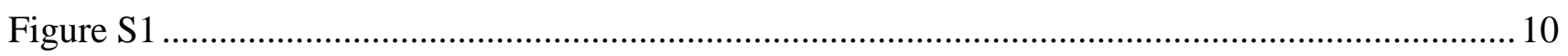




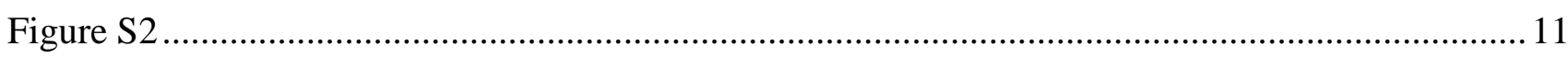

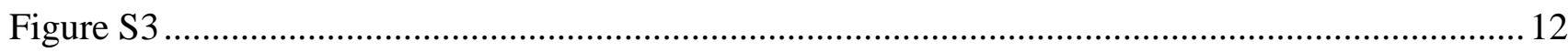

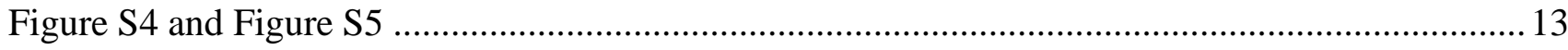

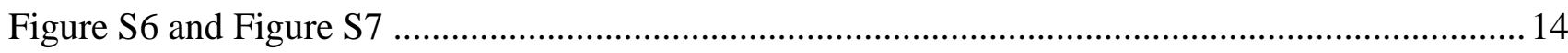

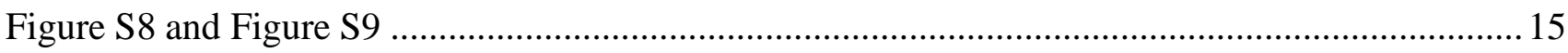

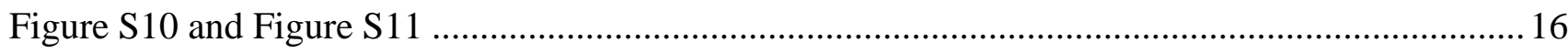

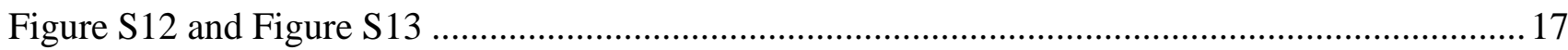

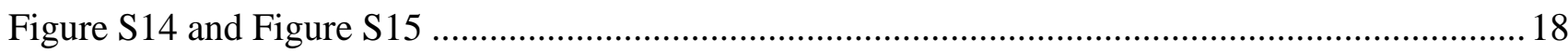

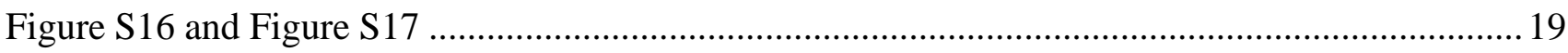

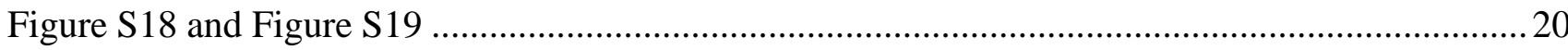

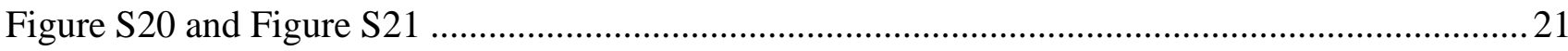

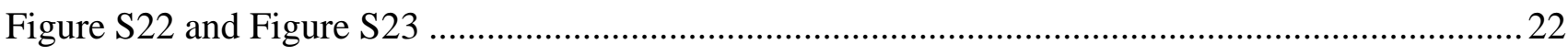

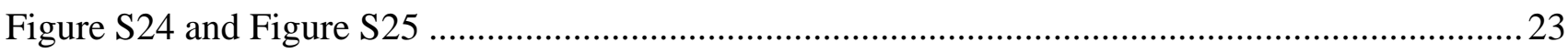

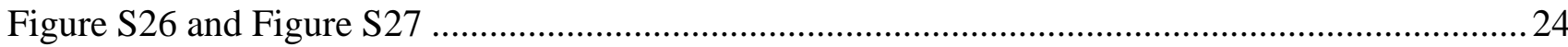

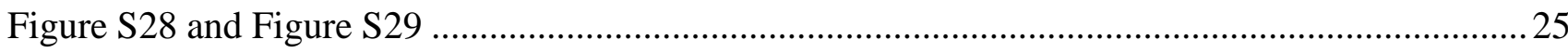

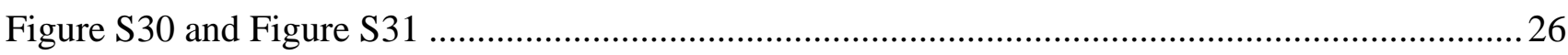

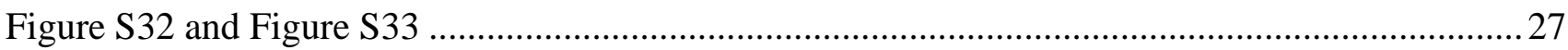

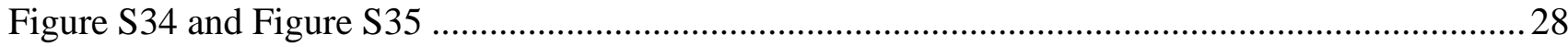

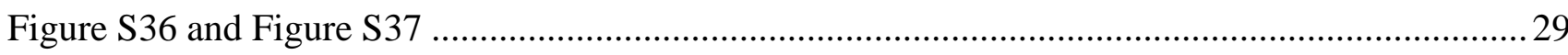

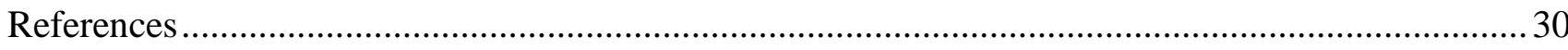

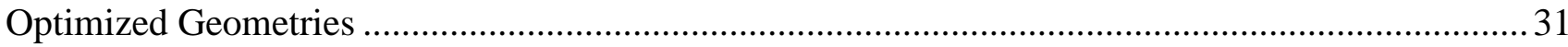




\section{Experimental Section}

\section{Materials}

Tetrahydrofuran (THF; Guangzhou Chemical Reagent, AR) was successively dried and distilled over molecular sieve $(4 \AA)$, calcium hydride $\left(\mathrm{CaH}_{2}\right)$, and $n$-butyl lithium $\left({ }^{n} \mathrm{BuLi}\right)$. cis-2-Butene-1,4-diol (BEDO; Aladdin, 97\%) and 1,8-diazabicyclo[5.4.0]undec-7-ene (DBU; TCI, 97\%) were dried twice by azeotropic distillation of purified THF then dissolved in THF into $0.50 \mathrm{M}$ solutions. Phenyl isothiocyanate (PhITC; Energy, 98\%), benzoyl isothiocyanate (BITC; Micxy, 97\%), p-tolyl isothiocyanate (TITC; Energy, 98\%), isopropyl isothiocyanate ( ${ }^{i} \operatorname{PrITC}$; Energy, 98\%), and $n$-propyl isothiocyanate ( ${ }^{n}$ PrITC; Energy, $98 \%$ ) were dried over $\mathrm{CaH}_{2}$ and distilled under vacuum before use. Propylene oxide (PO; Aldrich, 99\%), 1,2-butene oxide (BO; Aldrich, 99\%), and ally glycidyl ether (AGE; Aladdin, 99\%) were stirred over $\mathrm{CaH}_{2}$ overnight and distilled under vacuum. Ethylene oxide (EO; Aldrich, 99.5\%) was cryo-condensed from a metal cylinder into a Schlenk flask pre-charged with sodium hydride and stirred there in an ice-water bath for $4 \mathrm{~h}$, then cryo-condensed into a graduated Schlenk flask pre-charged with ${ }^{n} \mathrm{BuLi}$ and stirred there in an ice-water bath for $0.5 \mathrm{~h}$, and finally cryocondensed into the reaction flask. Acetic acid (AcOH; Aldrich, 99\%), methanol (Guangzhou Chemical Reagent, $\mathrm{AR}$ ), triethylborane ( $\mathrm{Et}_{3} \mathrm{~B}$; TCI, 1.0 M in THF), and phosphazene bases (PBs) including tertbutylimino-tris(dimethylamino)phosphorane $\quad\left({ }^{t} \mathrm{BuP}_{1} ; \quad\right.$ Aldrich, $\left.\quad 97 \%\right), \quad$ 1-tert-butyl-2,2,4,4,4pentakis(dimethylamino)- $2 \lambda^{5}, 4 \lambda^{5}$-catenadi(phosphazene) ( ${ }^{t} \mathrm{BuP}_{2}$; Aldrich, $2.0 \mathrm{M}$ in THF), and 1-tertbutyl-4,4,4-tris(dimethylamino)-2,2-bis[tris(dimethylamino)phosphoranylidenamino]- $2 \lambda^{5}, 4 \lambda^{5}$ catenadi(phosphazene) ( ${ }^{t} \mathrm{BuP}_{4}$; Aldrich, $0.8 \mathrm{M}$ in hexane) were store in a glovebox and used as received. Phthalic anhydride (PA; Aladdin, 99\%) was first sublimated under vacuum, then dissolved in acetic anhydride and stirred at $100{ }^{\circ} \mathrm{C}$ overnight before recrystallization at RT. 


\section{Instrumentation}

NMR spectra were recorded at $25{ }^{\circ} \mathrm{C}$ on a Bruker AV600 NMR spectrometer using deuterated chloroform $\left(\mathrm{CDCl}_{3}\right)$ as the solvent and tetramethylsilane $(\delta=0)$ as the internal reference. ${ }^{1} \mathrm{H}$ NMR spectra of the crude products of the copolymerization were used to calculate monomer conversion by comparing the integrals of signals from the residual monomers and the corresponding signals from the copolymers.

FTIR spectra were acquired with a resolution of $0.4 \mathrm{~cm}^{-1}$ on a Bruker Optics VERTEX 70 spectrometer. in situ ATR-IR spectra were recorded on a ReactIR ${ }^{\mathrm{TM}} 15$ spectrometer from METTLER-TOLEDO, equipped with a SE MCT detector via an $\mathrm{AgX}$ DiComp ${ }^{\mathrm{TM}}$ probe. Automatic sampling ranges from 4000 to $650 \mathrm{~cm}^{-1}$ at $4 \mathrm{~cm}^{-1}$ resolutions with a two-minutes headway.

Size exclusion chromatography (SEC) were conducted in THF at $35{ }^{\circ} \mathrm{C}$ using two identical PLgel MIXED-C columns at a flow rate of $1.0 \mathrm{~mL} \mathrm{mim}^{-1}$. The system was calibrated with a series of narrowly dispersed polystyrene standards to obtain apparent number-average molar mass $\left(M_{\mathrm{n}, \mathrm{SEC}}\right)$ and molar mass distribution $\left(\bigoplus_{\mathrm{M}}\right)$ of the copolymers.

\section{Calculation Details}

Calculations were conducted by Gaussian 16 Revision C.01 package. ${ }^{1}$ All structures were optimized under B3L YP/6-31+G(d) ${ }^{2,3,4-6}$ level of theory coupled with $\mathrm{SMD}^{7}$ solvation model $(\mathrm{PO}, \varepsilon=20.1046)^{8}$ and Grimme's DFT-D3 dispersion correction ${ }^{9}$ with BJ damping. ${ }^{10}$ Vibrational frequencies were calculated under the same level to obtain thermal correction information $(T=298.15 \mathrm{~K})$. Single point energies were further refined under M06-2X/6-311+G(d,p $)^{11,12}$ with DFT-D3 dispersion correction and SMD solvation model (PO). All transition state structures were confirmed by intrinsic reaction coordinate (IRC) ${ }^{13}$ calculation. The 3-D structures in this manuscript were depicted by CYLview 2.0. ${ }^{14}$ 


\section{Copolymerization Procedures}

Copolymerization of Isothiocyanates and Epoxides (except EO). Entry 2 in Table 1 is described here as a typical procedure. A pre-dried round-bottom reaction flask was transferred from an oven into a glovebox where BEDO (0.50 M in THF, $450.0 \mu \mathrm{L}, 0.225 \mathrm{mmol}), \mathrm{Et}_{3} \mathrm{~B}(1.0 \mathrm{M}, 13.4 \mu \mathrm{L}, 0.013 \mathrm{mmol})$, ${ }^{t} \mathrm{BuP}_{2}(2.0 \mathrm{M}, 11.2 \mu \mathrm{L}, 0.022 \mathrm{mmol})$, PhITC (0.80 mL, $\left.6.7 \mathrm{mmol}\right)$, and PO (0.7 mL, $\left.10.0 \mathrm{mmol}\right)$ were added successively. The mixture was stirred at room temperature (RT, $\left.23 \sim 26{ }^{\circ} \mathrm{C}\right)$ for $16 \mathrm{~h}$. Aliquots (ca. $50 \mu \mathrm{L}$ each) were withdrawn at different time intervals and diluted with $\mathrm{CDCl}_{3}(0.6 \mathrm{~mL})$ containing a drop of $\mathrm{AcOH}$ for ${ }^{1} \mathrm{H}$ NMR analysis. Part of the $\mathrm{CDCl}_{3}$ solution was further diluted with THF for SEC analysis. After quenching with a few drops of $\mathrm{AcOH}$, an aliquot of the crude product was withdrawn and used for ${ }^{1} \mathrm{H}$ NMR and SEC analysis to determine the copolymer composition, monomer conversion, $M_{\mathrm{n}, \mathrm{SEC}}$, and $\bigoplus_{\mathrm{M}}$. The remaining crude product was diluted with THF and precipitated in methanol. The white solid was collected by filtration and dried under vacuum at $50{ }^{\circ} \mathrm{C}$ overnight. Conv. $($ PhITC $)=89 \%$, Conv $.(\mathrm{PO})=59 \%, M_{\mathrm{n}, \mathrm{th}}=5.2 \mathrm{~kg} \mathrm{~mol}^{-1}, M_{\mathrm{n}, \mathrm{SEC}}=4.7 \mathrm{~kg} \mathrm{~mol}^{-1}, \bigoplus_{\mathrm{M}}=1.07 .{ }^{1} \mathrm{H}$ NMR $\left(600 \mathrm{MHz}, \mathrm{CDCl}_{3}\right): \delta / \mathrm{ppm}=7.29-6.71$ (aromatic protons of unreacted PhITC and $-\mathrm{C}\left(=\mathrm{NC}_{6} H_{5}\right) \mathrm{S}-$ in the copolymer $), 5.82\left(-\mathrm{OCH}_{2} \mathrm{CH}=\mathrm{CHCH}_{2} \mathrm{O}-\right.$ derived $\left.\mathrm{BEDO}\right)$, 5.47-5.25 $\left(-\mathrm{SCH}_{2} \mathrm{CH}\left(\mathrm{CH}_{3}\right) \mathrm{O}^{-}\right), 4.93\left(-\mathrm{OCH}_{2} \mathrm{CH}=\mathrm{CHCH}_{2} \mathrm{O}-\right.$ derived $\left.\mathrm{BEDO}\right), 3.31-2.84\left(-\mathrm{SCH}_{2} \mathrm{CH}\left(\mathrm{CH}_{3}\right) \mathrm{O}^{-}\right)$, 1.41-1.21 (- $\left.\mathrm{SCH}_{2} \mathrm{CH}\left(\mathrm{CH}_{3}\right) \mathrm{O}^{-}\right)$. FTIR (powder): $v / \mathrm{cm}^{-1}=1628,1592,1487,1155,1025$.

Copolymerization of PhITC and EO. Entry 10 in Table 2 is described here as a typical procedure. In a glovebox, BEDO (0.50 M in THF, $45.0 \mu \mathrm{L}, 0.023 \mathrm{mmol}), \mathrm{Et}_{3} \mathrm{~B}(1.0 \mathrm{M}, 13.4 \mu \mathrm{L}, 0.013 \mathrm{mmol}),{ }^{t} \mathrm{BuP}_{2}$ (2.0 M, $11.2 \mu \mathrm{L}, 0.022 \mathrm{mmol})$, and PhITC $(0.80 \mathrm{~mL}, 6.7 \mathrm{mmol})$ were added successively into a predried reaction flask. Then, the reaction flask was taken out of the glovebox and docked on the vacuum line to load purified EO $(0.50 \mathrm{~mL}, 10.0 \mathrm{mmol})$ via cryo-condensation at $-20{ }^{\circ} \mathrm{C}$. Subsequently, the 
reaction mixture was warmed up to RT and magnetically stirred, and completely converted to white solid in $12 \mathrm{~h}$. A small portion of the product was withdrawn for ${ }^{1} \mathrm{H}$ NMR and SEC analysis. The rest was dissolved in THF and poured into methanol to precipitated the copolymer which was then collected and dried in vacuum at $50{ }^{\circ} \mathrm{C}$ overnight. Conv. $($ PhITC $)=100 \%$, Conv. $(\mathrm{EO})=65 \%, M_{\mathrm{n}, \mathrm{th}}=$ $53.9 \mathrm{~kg} \mathrm{~mol}^{-1}, M_{\mathrm{n}, \mathrm{SEC}}=19.7 \mathrm{~kg} \mathrm{~mol}^{-1}, \bigoplus_{\mathrm{M}}=1.63 .{ }^{1} \mathrm{H} \mathrm{NMR}\left(600 \mathrm{MHz}, \mathrm{CDCl}_{3}\right): \delta / \mathrm{ppm}=7.35-6.72$ (aromatic protons of unreacted PhITC and $-\mathrm{C}\left(=\mathrm{NC}_{6} H_{5}\right) \mathrm{S}-$ in the copolymer), 4.50-4.27 $\left(-\mathrm{SCH}_{2} \mathrm{CH}_{2} \mathrm{O}^{-}\right)$, 3.25-3.07 (- $\left.\mathrm{SCH}_{2} \mathrm{CH}_{2} \mathrm{O}^{-}\right)$.

One-Pot Block Copolymerization of PhITC/PO and PO: Copolymerization-First Order. The procedure of entry 1 in Table 3 is as follows. BEDO (0.50 M in THF, 279.1 $\mu \mathrm{L}, 0.136 \mathrm{mmol}), \mathrm{Et}_{3} \mathrm{~B}(1.0 \mathrm{M}, 42.0$ $\mu \mathrm{L}, 0.042 \mathrm{mmol}),{ }^{t} \mathrm{BuP}_{2}(2.0 \mathrm{M}, 35.0 \mu \mathrm{L}, 0.070 \mathrm{mmol})$, PhITC (1.0 mL, $\left.8.4 \mathrm{mmol}\right)$, and PO (2.9 mL, $41.4 \mathrm{mmol}$ ) were successively loaded in a pre-dried round-bottom reaction flask in a glovebox. The mixture was stirred at RT for $12 \mathrm{~h}$. A small aliquot was withdrawn for ${ }^{1} \mathrm{H}$ NMR and SEC analysis. Conv. $(\mathrm{PhITC})=89 \%$, Conv. $(\mathrm{PO})$ in $\mathrm{PPO}=0 \%, M_{\mathrm{n}, \mathrm{th}}=10.4 \mathrm{~kg} \mathrm{~mol}^{-1}, M_{\mathrm{n}, \mathrm{SEC}}=10.7 \mathrm{~kg} \mathrm{~mol}^{-1}, \bigoplus_{\mathrm{M}}=$ 1.07.

Subsequently, Et 3 B (1.0 M, $97.7 \mu \mathrm{L}, 0.098 \mathrm{mmol})$ was promptly added into the reactor to "turn off" the $\mathrm{PhITC} / \mathrm{PO}$ alternating copolymerization and simultaneously "turn on" the ring-opening polymerization (ROP) of PO. After $1 \mathrm{~h}$, the second aliquot was withdrawn for ${ }^{1} \mathrm{H}$ NMR and SEC analysis. The reaction was quenched by addition of a few drops of $\mathrm{AcOH}$. The block copolymer was precipitated in methanol, collected, and dried in vacuum at $50{ }^{\circ} \mathrm{C}$ overnight. Conv. $(\mathrm{PhITC})=89 \%$, Conv.(PO) in PPO $=80 \%, M_{\mathrm{n}, \mathrm{th}}=24.4 \mathrm{~kg} \mathrm{~mol}^{-1}, M_{\mathrm{n}, \mathrm{SEC}}=30.2 \mathrm{~kg} \mathrm{~mol}^{-1}, \bigoplus_{\mathrm{M}}=1.06 .{ }^{1} \mathrm{H} \mathrm{NMR}(600$ $\left.\mathrm{MHz}, \mathrm{CDCl}_{3}\right): \delta / \mathrm{ppm}=7.29-6.71$ (aromatic protons of unreacted PhITC and $-\mathrm{C}\left(=\mathrm{NC}_{6} H_{5}\right) \mathrm{S}-$ in the copolymer), $5.82\left(-\mathrm{OCH}_{2} \mathrm{CH}=\mathrm{CHCH}_{2} \mathrm{O}-\right.$ derived from BEDO), 5.52-5.25 $\left(-\mathrm{SCH}_{2} \mathrm{CH}\left(\mathrm{CH}_{3}\right) \mathrm{O}-\right), 4.91$ 
$\left(-\mathrm{OCH}_{2} \mathrm{CH}=\mathrm{CHCH}_{2} \mathrm{O}-\quad\right.$ derived from $\left.\mathrm{BEDO},\right), \quad 3.92 \quad\left(-\mathrm{CH}_{2} \mathrm{CH}\left(\mathrm{CH}_{3}\right) \mathrm{OH}\right), \quad 3.71-3.26$ $\left(-\mathrm{OCH}_{2} \mathrm{CH}\left(\mathrm{CH}_{3}\right) \mathrm{O}^{-}\right), 3.26-2.84\left({ }^{-} \mathrm{SCH}_{2} \mathrm{CH}\left(\mathrm{CH}_{3}\right) \mathrm{O}^{-}\right), 1.45-1.21 \quad\left(-\mathrm{SCH}_{2} \mathrm{CH}\left(\mathrm{CH}_{3}\right) \mathrm{O}^{-}\right), 1.21-1.05$ $\left(-\mathrm{OCH}_{2} \mathrm{CH}\left(\mathrm{CH}_{3}\right) \mathrm{O}^{-}\right)$.

One-Pot Block Copolymerization of PhITC/PO and PO: Homopolymerization-First Order. The procedure of entry 2 in Table 3 is as follows. BEDO $(0.50 \mathrm{M}, 279.1 \mu \mathrm{L}, 0.140 \mathrm{mmol}), \mathrm{Et}_{3} \mathrm{~B}(1.0 \mathrm{M}$, $42.0 \mu \mathrm{L}, 0.042 \mathrm{mmol}),{ }^{t} \mathrm{BuP}_{2}(2.0 \mathrm{M}, 7.0 \mu \mathrm{L}, 0.014 \mathrm{mmol})$, PhITC (1.0 mL, $\left.8.4 \mathrm{mmol}\right)$, and PO (2.9 $\mathrm{mL}, 41.4 \mathrm{mmol}$ ) were loaded in a pre-dried round-bottom reaction flask in a glovebox. The mixture was stirred at RT for $4 \mathrm{~h}$. Then, a small aliquot was quickly withdrawn for ${ }^{1} \mathrm{H}$ NMR and SEC analysis. Conv.(PhITC) $=0 \%$, Conv. $(\mathrm{PO})$ in $\mathrm{PPO}=58 \%, M_{\mathrm{n}, \mathrm{th}}=10.2 \mathrm{~kg} \mathrm{~mol}^{-1}, M_{\mathrm{n}, \mathrm{SEC}}=16.3 \mathrm{~kg} \mathrm{~mol}^{-1}, \bigoplus_{\mathrm{M}}=$ 1.04 .

Then, ${ }^{t} \mathrm{BuP}_{2}(2.0 \mathrm{M}, 42.0 \mu \mathrm{L}, 0.084 \mathrm{mmol})$ was quickly added in the reaction flask to "turn off" the ROP of PO and "turn on" the PhITC/PO alternating copolymerization. After $32 \mathrm{~h}$, the reaction was quenched by addition of a few drops of $\mathrm{AcOH}$, after which another aliquot was withdrawn for ${ }^{1} \mathrm{H}$ NMR and SEC analysis. The rest of the crude product was diluted with THF, poured in methanol to precipitate the block copolymer which was then collected and dried in a vacuum at $50{ }^{\circ} \mathrm{C}$ overnight. Conv. $(\mathrm{PhITC})=80 \%$, Conv. $(\mathrm{PO})$ in $\mathrm{PPO}=58 \% \cdot M_{\mathrm{n}, \mathrm{h}}=19.5 \mathrm{~kg} \mathrm{~mol}^{-1}, M_{\mathrm{n}, \mathrm{SEC}}=23.8 \mathrm{~kg} \mathrm{~mol}^{-1}, \bigoplus_{\mathrm{M}}=$ 1.08. ${ }^{1} \mathrm{H}$ NMR $\left(600 \mathrm{MHz}, \mathrm{CDCl}_{3}\right): \delta / \mathrm{ppm}=7.29-6.71$ (aromatic protons of unreacted $\mathrm{PhITC}$ and $-\mathrm{C}\left(=\mathrm{NC}_{6} H_{5}\right) \mathrm{S}-$ in the copolymer $), 5.81\left(-\mathrm{OCH}_{2} \mathrm{CH}=\mathrm{CHCH}_{2} \mathrm{O}-\right.$ derived from BEDO $)$, 5.52-5.25 $\left(-\mathrm{SCH}_{2} \mathrm{CH}\left(\mathrm{CH}_{3}\right) \mathrm{O}^{-}\right), \quad 4.91 \quad\left(-\mathrm{OCH}_{2} \mathrm{CH}=\mathrm{CHCH}_{2} \mathrm{O}-\quad\right.$ derived from $\left.\mathrm{BEDO}\right), \quad 3.71-3.26$ $\left(-\mathrm{OCH}_{2} \mathrm{CH}\left(\mathrm{CH}_{3}\right) \mathrm{O}-\right), 3.26-2.81 \quad\left(-\mathrm{SCH}_{2} \mathrm{CH}\left(\mathrm{CH}_{3}\right) \mathrm{O}-\right), 1.45-1.21 \quad\left(-\mathrm{SCH}_{2} \mathrm{CH}\left(\mathrm{CH}_{3}\right) \mathrm{O}^{-}\right), 1.21-1.05$ $\left(-\mathrm{OCH}_{2} \mathrm{CH}\left(\mathrm{CH}_{3}\right) \mathrm{O}^{-}\right)$.

One-Step Block Terpolymerization of PA/PO and PhITC/PO. The synthetic procedure for the reaction 
shown in Figure 4 is as follows. PA (0.372 g, $2.5 \mathrm{mmol})$, PhITC (0.30 mL, $2.5 \mathrm{mmol}), \mathrm{PO}(0.88 \mathrm{~mL}$, $12.6 \mathrm{mmol}), \mathrm{BEDO}(0.50 \mathrm{M}, 100.5 \mu \mathrm{L}, 0.050 \mathrm{mmol}), \mathrm{Et}_{3} \mathrm{~B}(1.0 \mathrm{M}, 15.1 \mu \mathrm{L}, 0.015 \mathrm{mmol})$, and ${ }^{t} \mathrm{BuP}_{2}$ (2.0 M, $12.6 \mu \mathrm{L}, 0.025 \mathrm{mmol})$ were added successively into a pre-dried round-bottom reaction flask in a glovebox. The mixture was stirred at RT and sampled from time to time for ${ }^{1} \mathrm{H}$ NMR and SEC analysis until both PhITC and PA are (almost) fully consumed. After 10 hours, Conv.(PhITC) $=0 \%$, Conv. $(\mathrm{PO})=21 \%$, Conv. $(\mathrm{PA})=97 \%, M_{\mathrm{n}, \mathrm{th}}=10.1 \mathrm{~kg} \mathrm{~mol}^{-1}, M_{\mathrm{n}, \mathrm{SEC}}=9.7 \mathrm{~kg} \mathrm{~mol}^{-1}, \bigoplus_{\mathrm{M}}=1.08$. After 11 hours, Conv. $(\mathrm{PhITC})=5 \%$, Conv. $(\mathrm{PO})=23 \%$, Conv. $(\mathrm{PA})=100 \%, M_{\mathrm{n}, \mathrm{th}}=10.9 \mathrm{~kg} \mathrm{~mol}^{-1}, M_{\mathrm{n}, \mathrm{SEC}}=$ $10.6 \mathrm{~kg} \mathrm{~mol}^{-1}, \bigoplus_{\mathrm{M}}=1.08$. After 20 hours, the reaction was quenched by a few drops of AcOH, after which another aliquot was withdrawn for ${ }^{1} \mathrm{H}$ NMR and SEC analysis. The rest of the crude product was diluted with THF, poured in methanol to precipitate the block terpolymer which was then collected and dried in a vacuum at $50{ }^{\circ} \mathrm{C}$ overnight. Conv.(PhITC) $=96 \%$, Conv.(PO) $=44 \%$, Conv.(PA) $=$ $100 \%, M_{\mathrm{n}, \mathrm{th}}=19.7 \mathrm{~kg} \mathrm{~mol}^{-1}, M_{\mathrm{n}, \mathrm{SEC}}=18.6 \mathrm{~kg} \mathrm{~mol}^{-1}, \bigoplus_{\mathrm{M}}=1.12 .{ }^{1} \mathrm{H} \mathrm{NMR}\left(600 \mathrm{MHz}, \mathrm{CDCl}_{3}\right): \delta / \mathrm{ppm}$ $=7.78-7.43\left(-\mathrm{OOCC}_{6} \mathrm{H}_{4} \mathrm{COO}-\right.$ in the terpolymer $)$, 7.29-6.71 (aromatic protons of unreacted PhITC and $-\mathrm{C}\left(=\mathrm{NC}_{6} H_{5}\right) \mathrm{S}-$ in the terpolymer $), 5.84\left(-\mathrm{OCH}_{2} \mathrm{CH}=\mathrm{CHCH}_{2} \mathrm{O}-\right.$ derived from BEDO $), 5.62-5.24$ $\left(-\mathrm{OCH}_{2} \mathrm{CH}\left(\mathrm{CH}_{3}\right) \mathrm{OCO}-\right.$ and $\left.-\mathrm{SCH}_{2} \mathrm{CH}\left(\mathrm{CH}_{3}\right) \mathrm{O}^{-}\right), 4.88\left(-\mathrm{OCH}_{2} \mathrm{CH}=\mathrm{CHCH}_{2} \mathrm{O}-\right.$ derived from $\left.\mathrm{BEDO}\right)$, 4.50-4.29 (- $\left.\mathrm{OCH}_{2} \mathrm{CH}\left(\mathrm{CH}_{3}\right) \mathrm{OCO}-\right)$, 3.31-2.85 (- $\left.\mathrm{SCH}_{2} \mathrm{CH}\left(\mathrm{CH}_{3}\right) \mathrm{O}^{-}\right)$, 1.49-1.15 $\left(-\mathrm{OCH}_{2} \mathrm{CH}\left(\mathrm{CH}_{3}\right) \mathrm{O}^{-}\right.$ and $\left.-\mathrm{SCH}_{2} \mathrm{CH}\left(\mathrm{CH}_{3}\right) \mathrm{O}-\right)$. 
Table S1. Additional experiments on the copolymerization of PO and PhITC initiated by BEDO. ${ }^{a}$

\begin{tabular}{cclcccccccc}
\hline entry & base & PhITC/PO/I/B/Et $\mathrm{B}^{b}$ & $\begin{array}{c}\text { time } \\
(\mathrm{h})\end{array}$ & $\begin{array}{c}\text { temp } \\
\left({ }^{\circ} \mathrm{C}\right)\end{array}$ & $\begin{array}{c}\mathrm{conv}^{c} \\
(\%)\end{array}$ & $\begin{array}{c}\mathrm{LS}^{d} \\
(\%)\end{array}$ & $\begin{array}{c}\mathrm{EC}^{e} \\
(\%)\end{array}$ & $\begin{array}{c}M_{\mathrm{n}, \mathrm{th}}{ }^{f} \\
\left(\mathrm{~kg} \mathrm{~mol}^{-1}\right)\end{array}$ & $\begin{array}{c}M_{\mathrm{n}, \mathrm{SEC}^{g}} \\
\left(\mathrm{~kg} \mathrm{~mol}^{-1}\right)\end{array}$ & $D_{\mathrm{M}^{g}}$ \\
\hline 1 & ${ }^{t} \mathrm{BuP}_{1}$ & $20 / 30 / 1 / 0.1 / 0$ & 24 & $\mathrm{RT}$ & - & - & - & - & - & - \\
2 & ${ }^{t} \mathrm{BuP}_{1}$ & $20 / 30 / 1 / 0.1 / 0.06$ & 24 & $\mathrm{RT}$ & - & - & - & - & - & - \\
3 & ${ }^{t} \mathrm{BuP}_{4}$ & $300 / 450 / 0.5 / 1 / 0.6$ & 144 & $\mathrm{RT}$ & 100 & $>99$ & 0 & 116.1 & 19.3 & 2.01 \\
\hline
\end{tabular}

${ }^{a}$ Initiator and catalysts are added in THF or $n$-hexane (only for ${ }^{t} \mathrm{BuP}_{4}$ ) solutions. $[\mathrm{PhITC}]_{0}=3.43 \sim 4.46$ M. ${ }^{b}$ Molar feed ratio of PhITC, PO, BEDO, base (B), and Et ${ }_{3} B .{ }^{c}$ Conversion of PhITC determined by ${ }^{1} \mathrm{H}$ NMR. ${ }^{d}$ Linear selectivity. ${ }^{e}$ Ether content. ${ }^{f}$ Theoretical molar mass. ${ }^{g}$ Determined by SEC in THF at $35^{\circ} \mathrm{C}$ using PS standards.

Table S2. The $\mathrm{p} K_{\mathrm{a}}$ values in acetonitrile of organobases used in this work. ${ }^{15-17}$

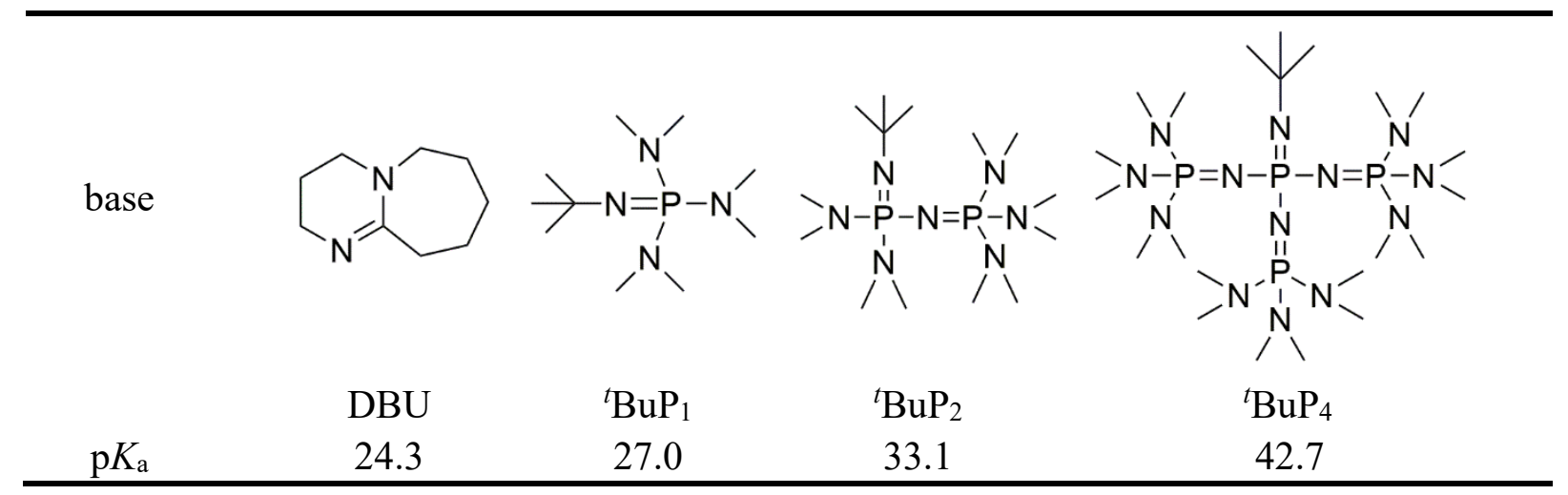



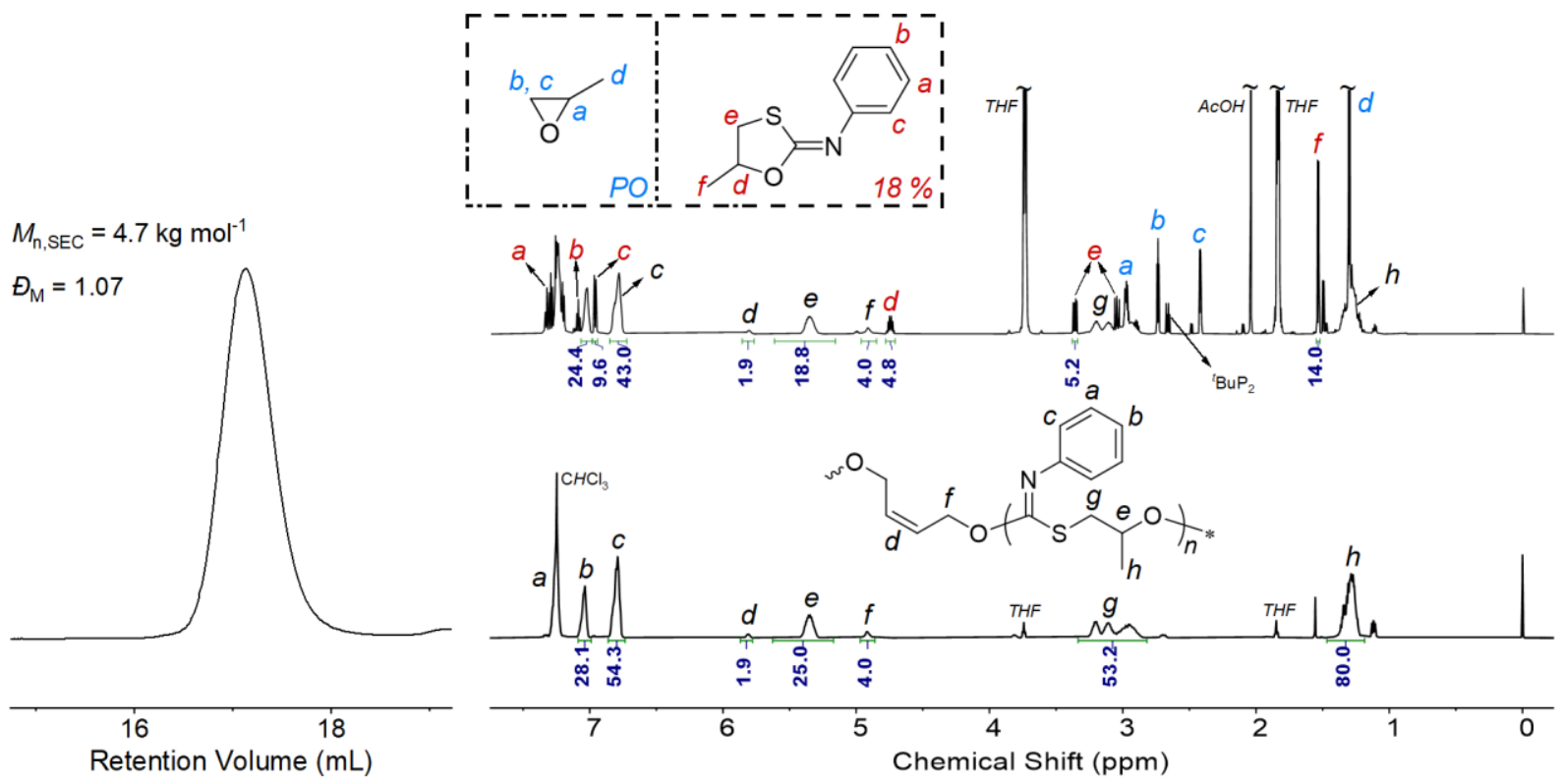

Figure S1. SEC trace (left) of the isolated copolymer and ${ }^{1} \mathrm{H}$ NMR spectra (right; in $\mathrm{CDCl}_{3}$ ) of both the crude product and the isolated copolymer from the copolymerization of PhITC and PO catalyzed by ${ }^{t} \mathrm{BuP}_{2}$ alone (entry 1 in Table1). Linear selectivity (LS) is calculated from the ${ }^{1} \mathrm{H}$ NMR spectrum of the crude product using integrals $(I)$ of characteristic proton signals of the copolymer and the cyclic product as $I_{\mathrm{c}}($ black $) /\left[I_{\mathrm{c}}(\right.$ red $)+I_{\mathrm{c}}($ black $\left.)\right]=43.0 /(43.0+9.6)=0.82$. 


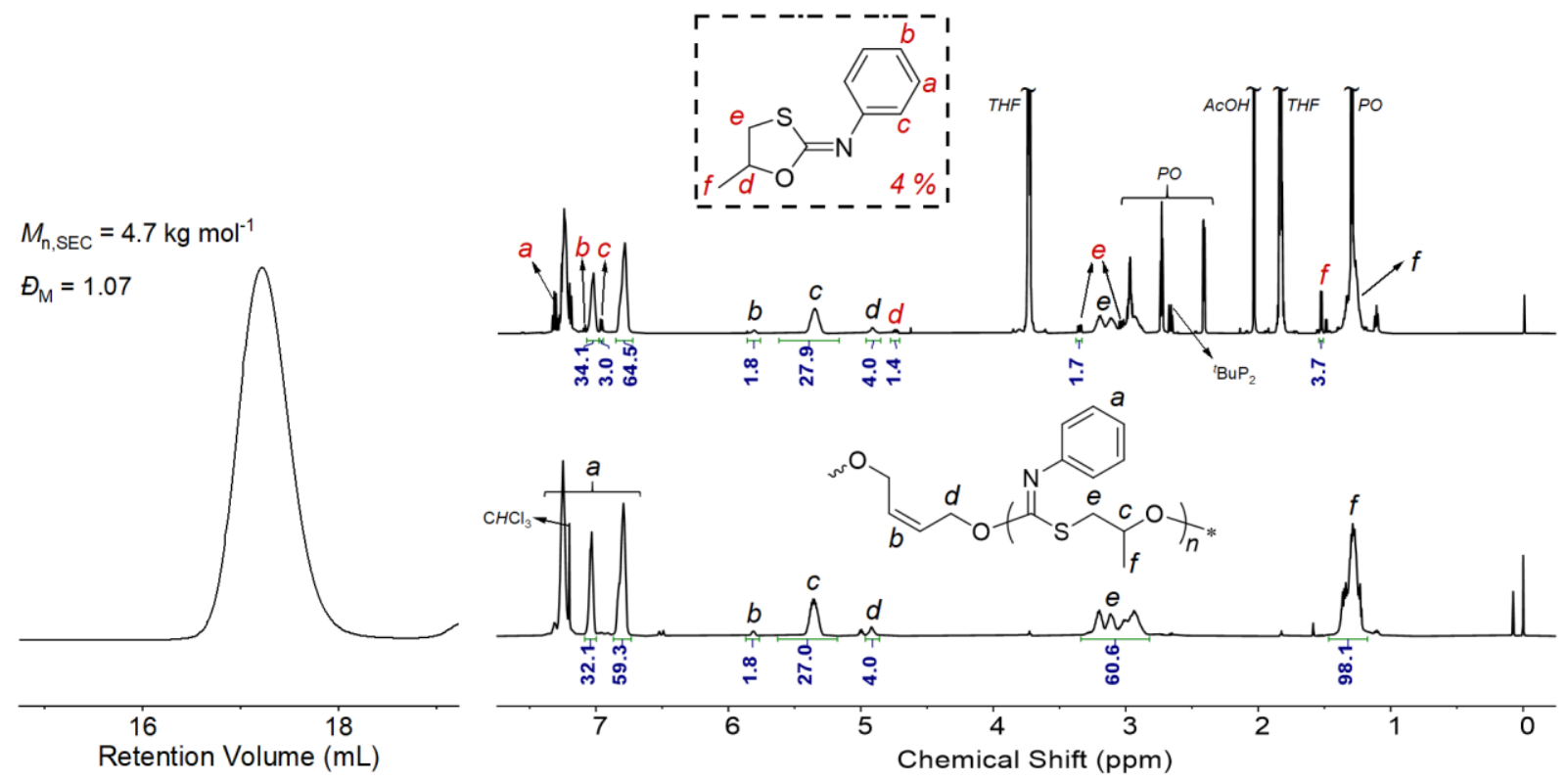

Figure S2. SEC trace (left) of the isolated copolymer and ${ }^{1} \mathrm{H} \mathrm{NMR}$ spectra (right; in $\mathrm{CDCl}_{3}$ ) of the both the crude product and the isolated copolymer from the copolymerization of PhITC and PO catalyzed by ${ }^{t} \mathrm{BuP}_{2} / \mathrm{Et}_{3} \mathrm{~B}$ (1/0.6) with excess ${ }^{t} \mathrm{BuP}_{2}$ (entry 2 in Table 1$)$. 
(a)

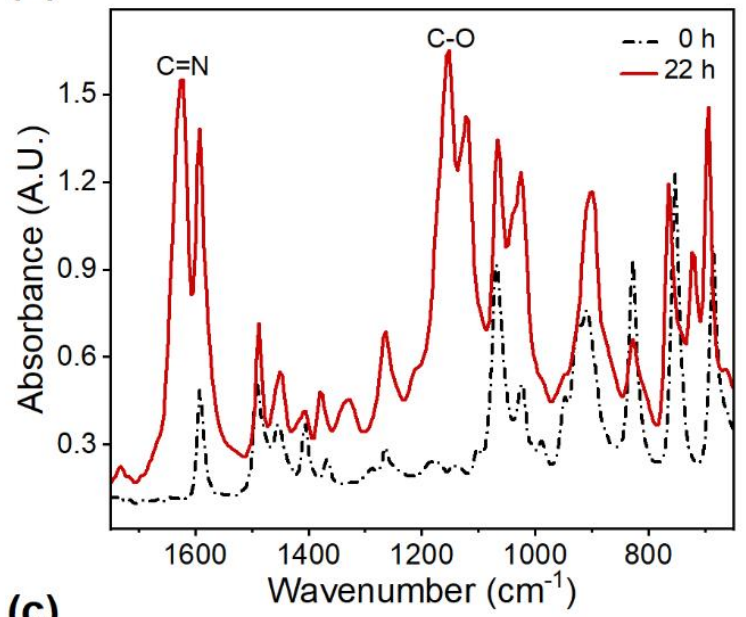

(c)

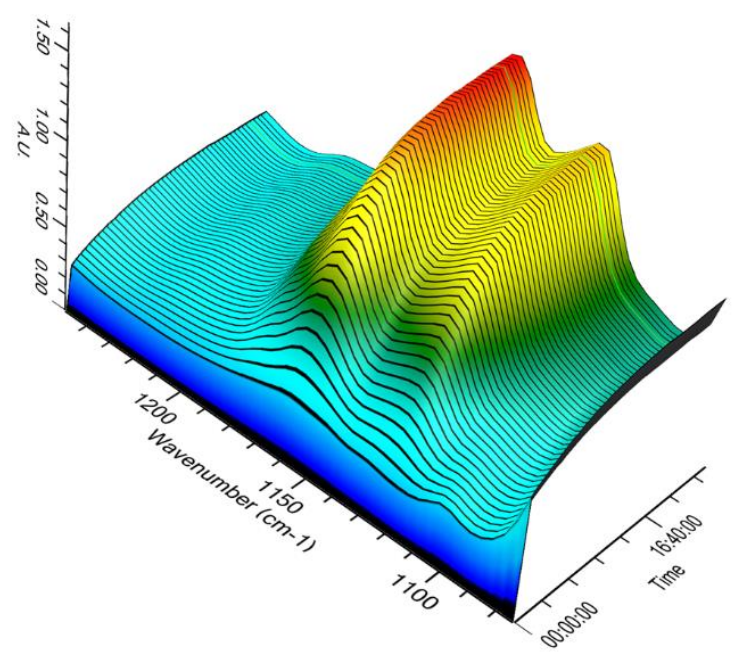

(b)

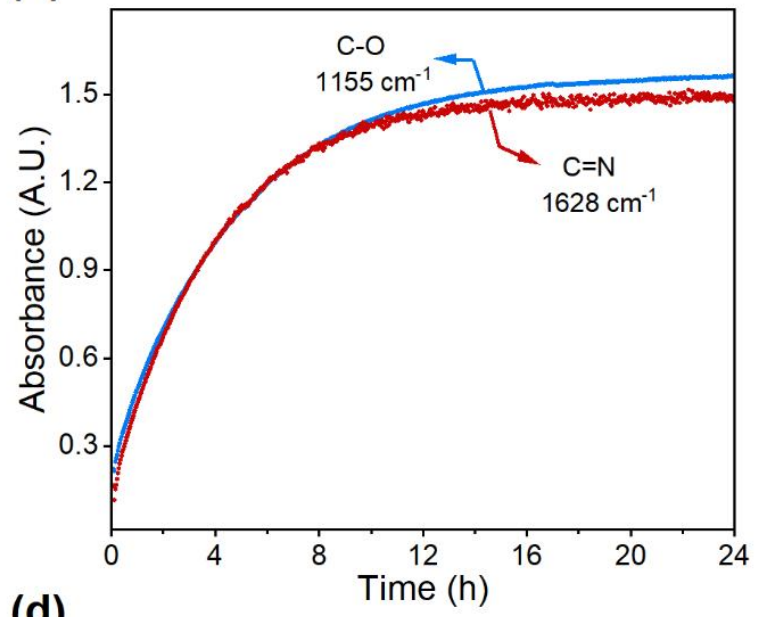

(d)

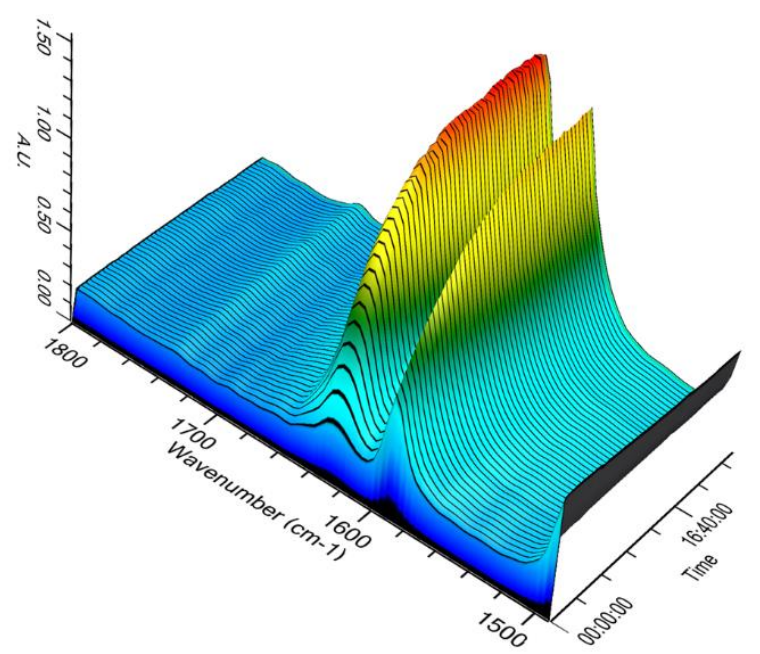

Figure S3. (a) The in situ ATR-IR spectra obtained during the PhITC/PO copolymerization at $0 \mathrm{~h}$ and $22 \mathrm{~h}$ (entry 2 in Table 1). (b) Time-dependent peak intensity at $1155 \mathrm{~cm}^{-1}$ and $1628 \mathrm{~cm}^{-1}$. Threedimensional infrared absorption profiles of the peaks at $1155 \mathrm{~cm}^{-1}$ (c) and $1628 \mathrm{~cm}^{-1}(\mathrm{~d})$. 


$$
M_{\mathrm{n}, \mathrm{SEC}}\left(\mathrm{kg} \mathrm{mol}^{-1}\right) / \oplus_{\mathrm{M}}
$$
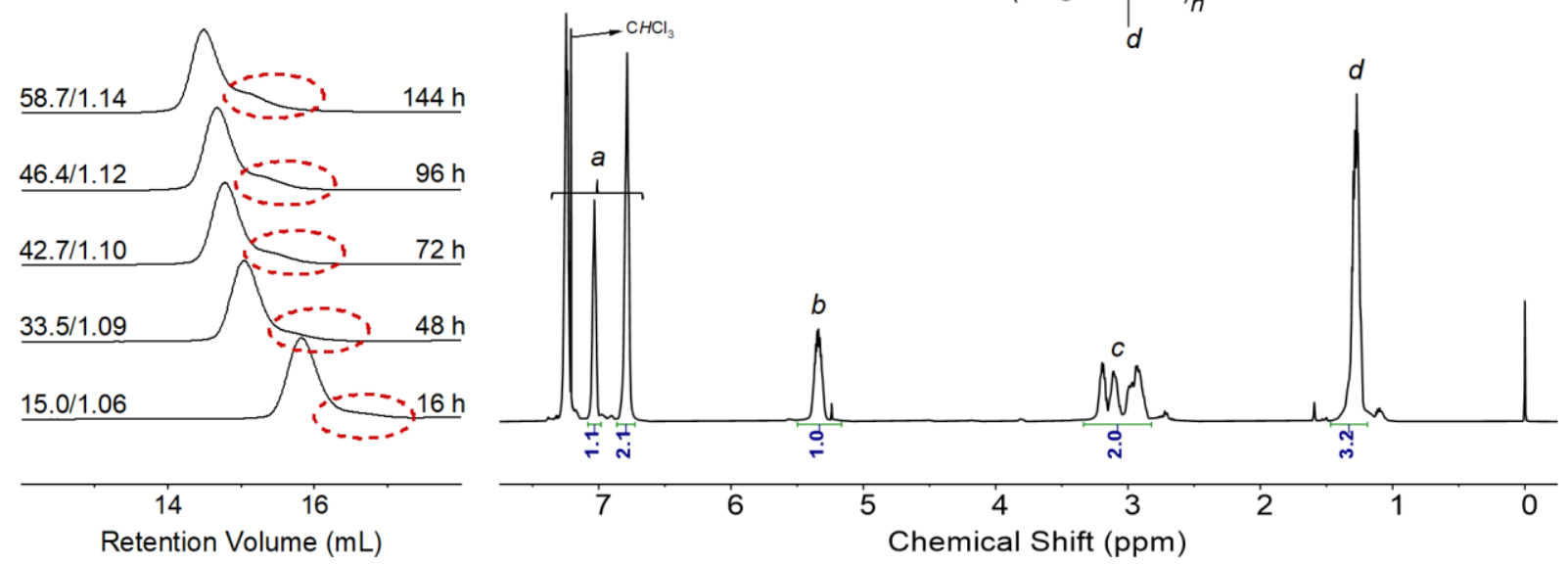

Figure S4. Evolution of SEC traces (left) of the crude products obtained at different reaction times and ${ }^{1} \mathrm{H}$ NMR spectrum (right; in $\mathrm{CDCl}_{3}$ ) of the isolated high-molar-mass copolymer from the copolymerization of PhITC and PO catalyzed by ${ }^{t} \mathrm{BuP}_{2} / \mathrm{Et}_{3} \mathrm{~B}$ with excess ${ }^{t} \mathrm{BuP}_{2}$ (entry 6 in Table 1 ).

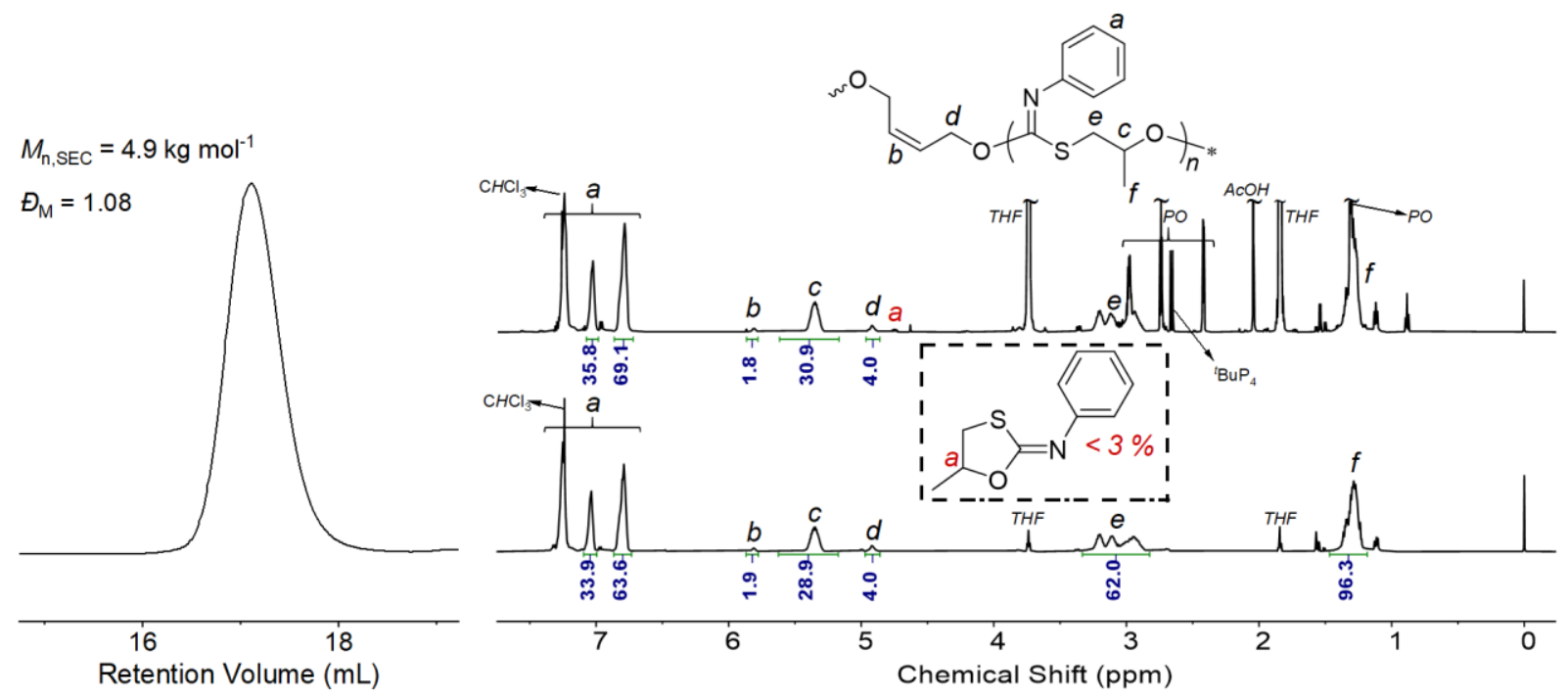

Figure S5. SEC trace (left) of the isolated copolymer and ${ }^{1} \mathrm{H}$ NMR spectra (right; in $\mathrm{CDCl}_{3}$ ) of both the crude product and the isolated copolymer from the copolymerization of PhITC and PO catalyzed by ${ }^{t} \mathrm{BuP}_{4} / \mathrm{Et}_{3} \mathrm{~B}$ with excess ${ }^{t} \mathrm{BuP}_{4}$ (entry 7 in Table 1 ). 

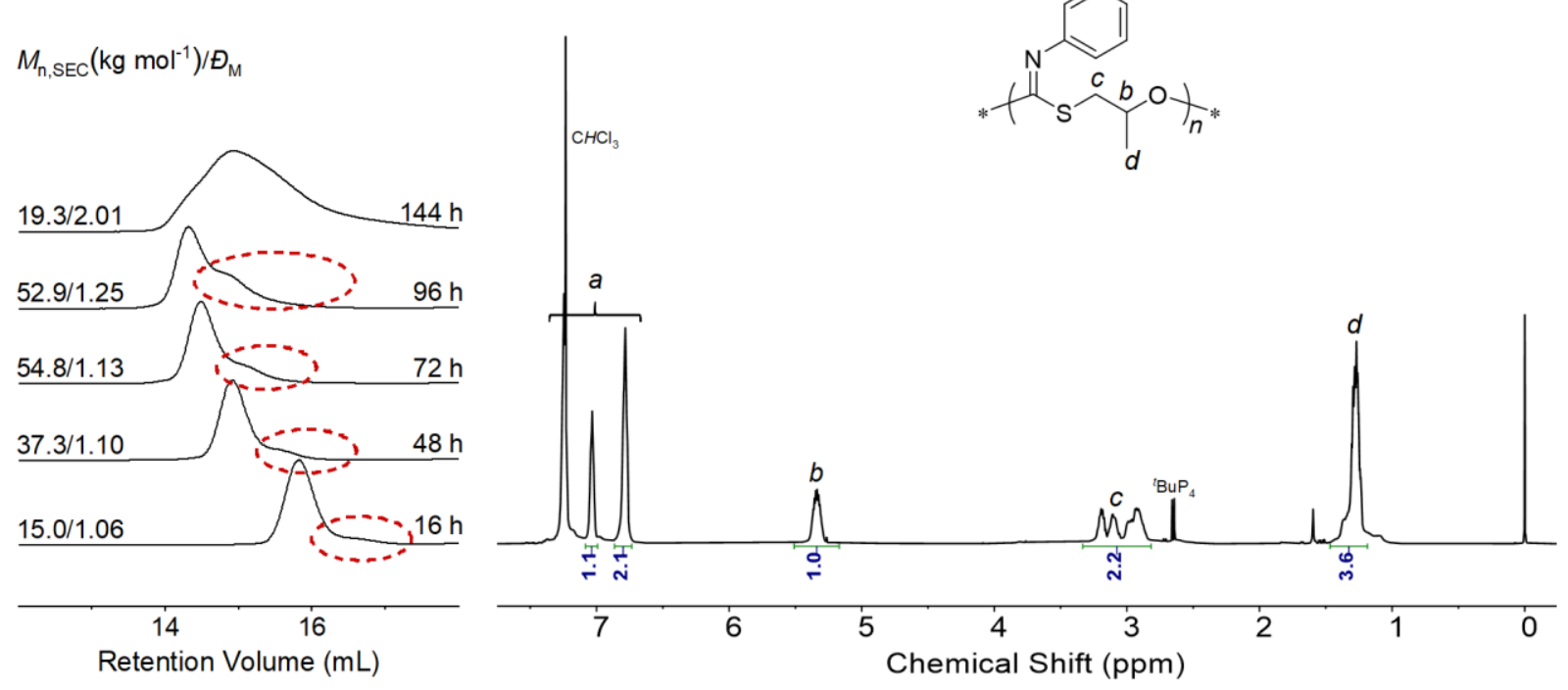

Figure S6. Evolution of SEC traces (left) of the crude products obtained at different reaction times and ${ }^{1} \mathrm{H}$ NMR spectrum (right; in $\mathrm{CDCl}_{3}$ ) of the isolated copolymer from the copolymerization of PhITC and PO catalyzed by ${ }^{t} \mathrm{BuP}_{4} / \mathrm{Et}_{3} \mathrm{~B}$ with excess ${ }^{t} \mathrm{BuP}_{4}$ (entry 3 in Table $\mathrm{S} 1$ ).

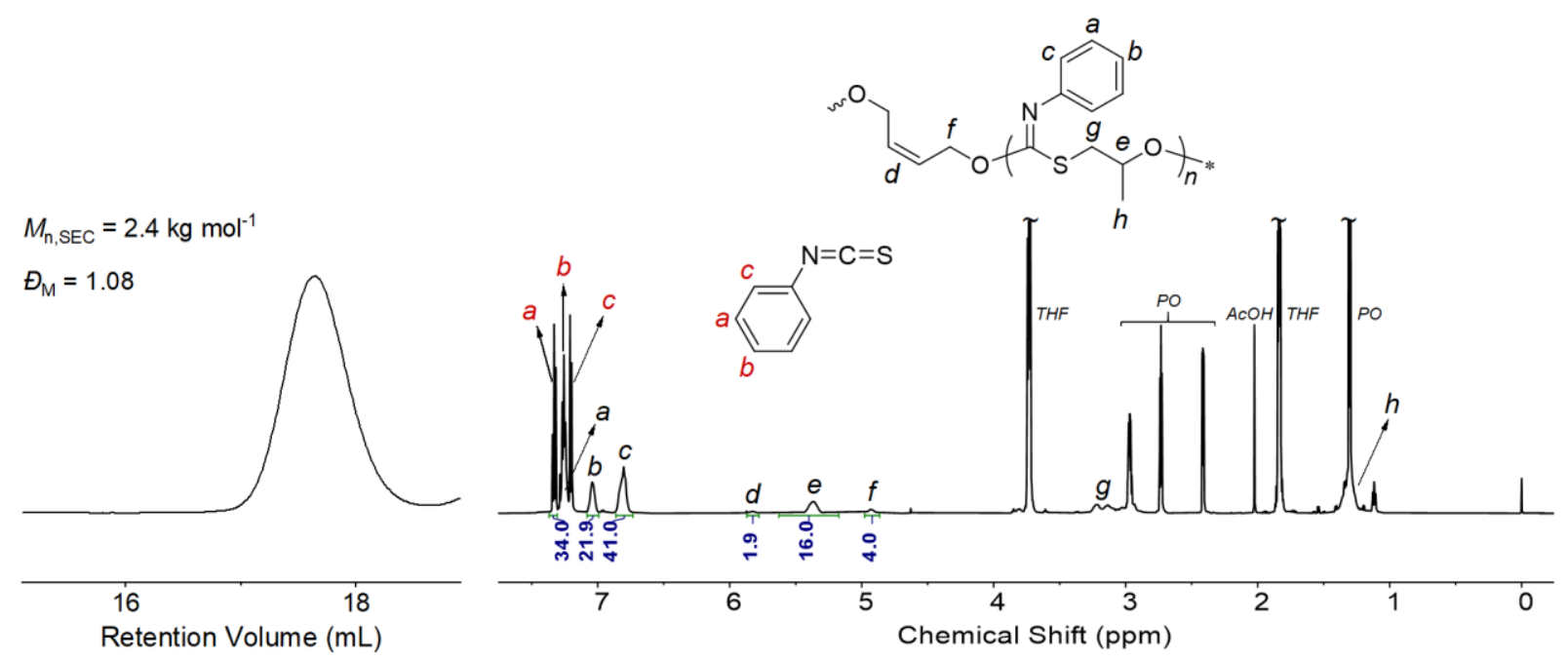

Figure S7. SEC trace (left) and ${ }^{1} \mathrm{H}$ NMR spectrum (right; in $\mathrm{CDCl}_{3}$ ) of the crude product from the copolymerization of PhITC and PO catalyzed by DBU/Et 3 B with excess DBU (entry 8 in Table 1). 

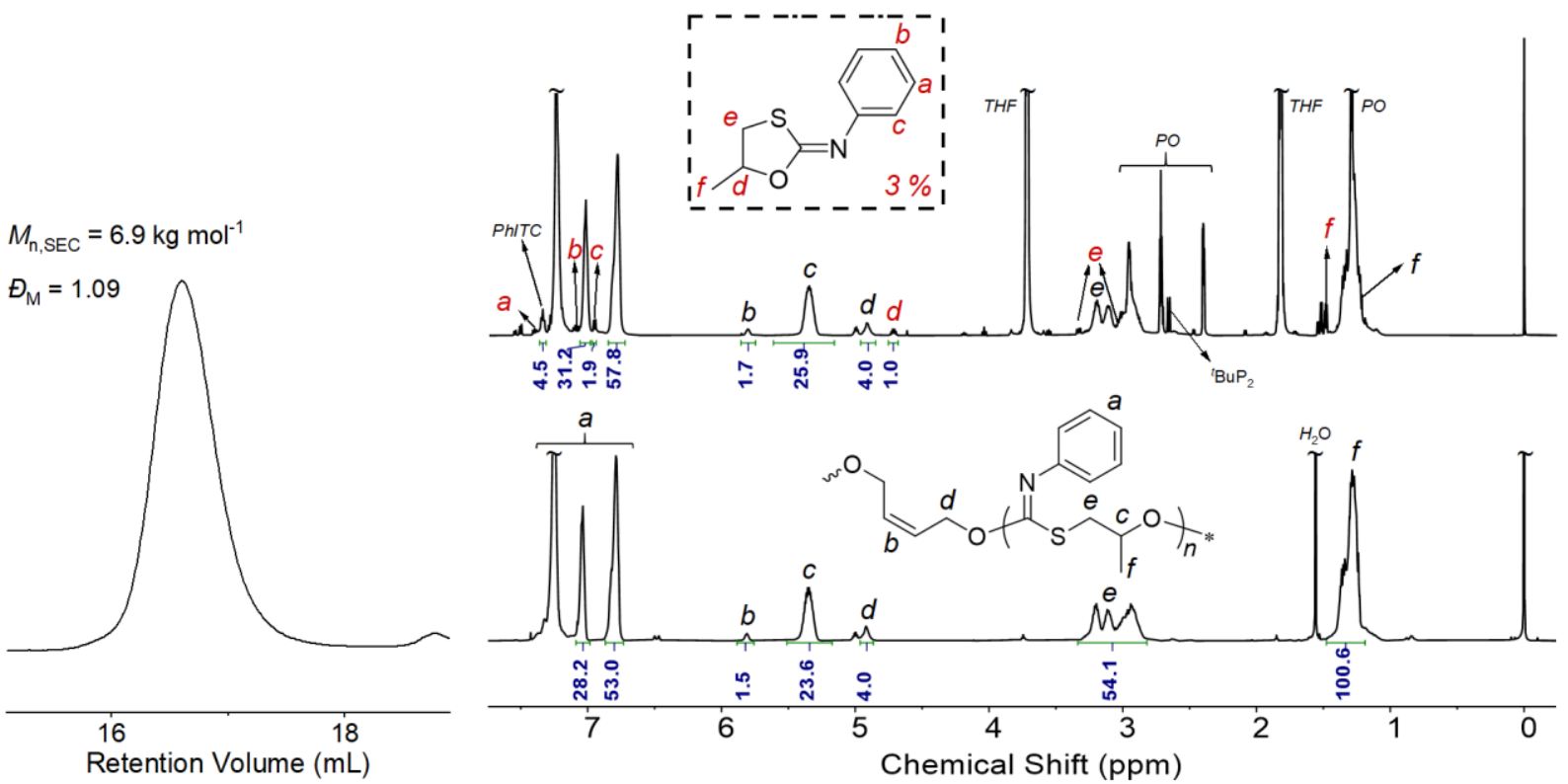

Figure S8. SEC trace (left) of the isolated copolymer and ${ }^{1} \mathrm{H}$ NMR spectra (right; in $\mathrm{CDCl}_{3}$ ) of both the crude product and the isolated copolymer from the copolymerization of PhITC and PO catalyzed by ${ }^{t} \mathrm{BuP}_{2} / \mathrm{Et}_{3} \mathrm{~B}(1 / 0.3)$ with excess ${ }^{t} \mathrm{BuP}_{2}$ (entry 9 in Table 1$)$.

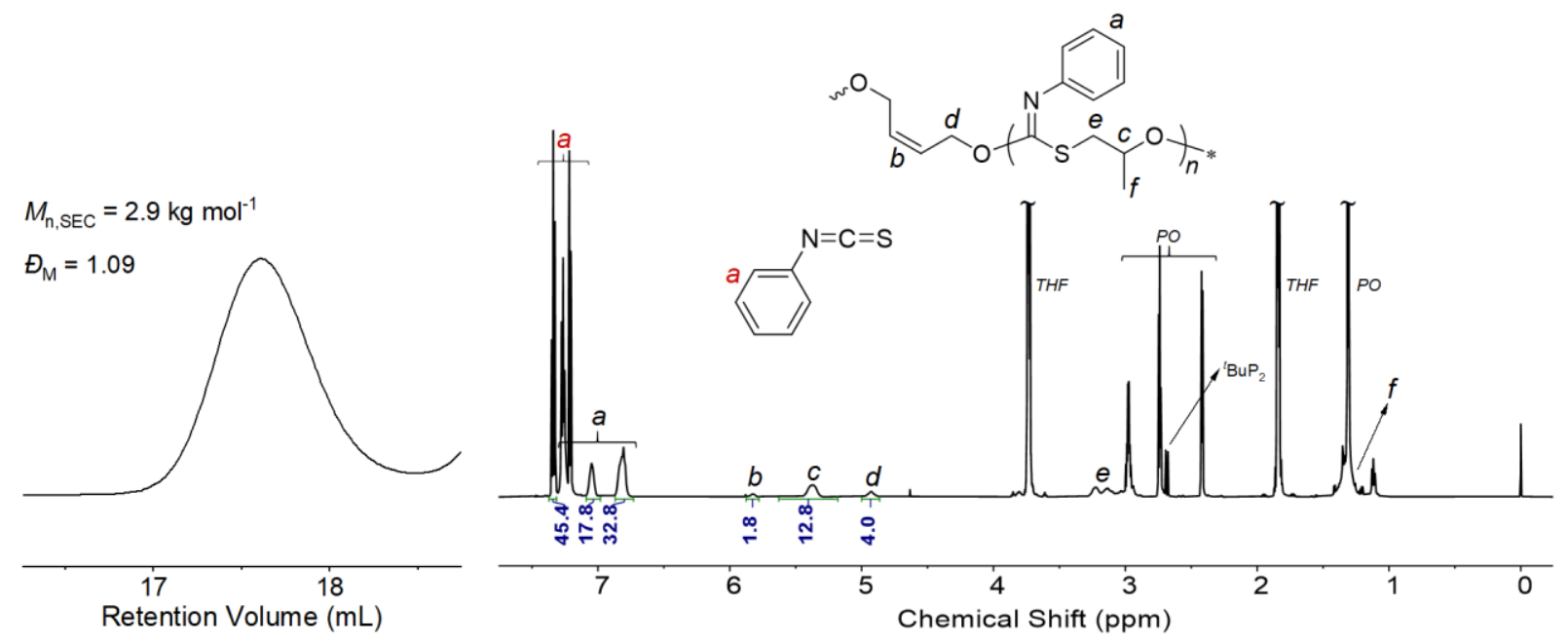

Figure S9. SEC trace (left) and ${ }^{1} \mathrm{H}$ NMR spectrum (right; in $\mathrm{CDCl}_{3}$ ) of the crude product from the copolymerization of PhITC and PO catalyzed by ${ }^{t} \mathrm{BuP}_{2} / \mathrm{Et}_{3} \mathrm{~B}$ (1/0.9) with excess ${ }^{t} \mathrm{BuP}_{2}$ (entry 10 in Table 1). 


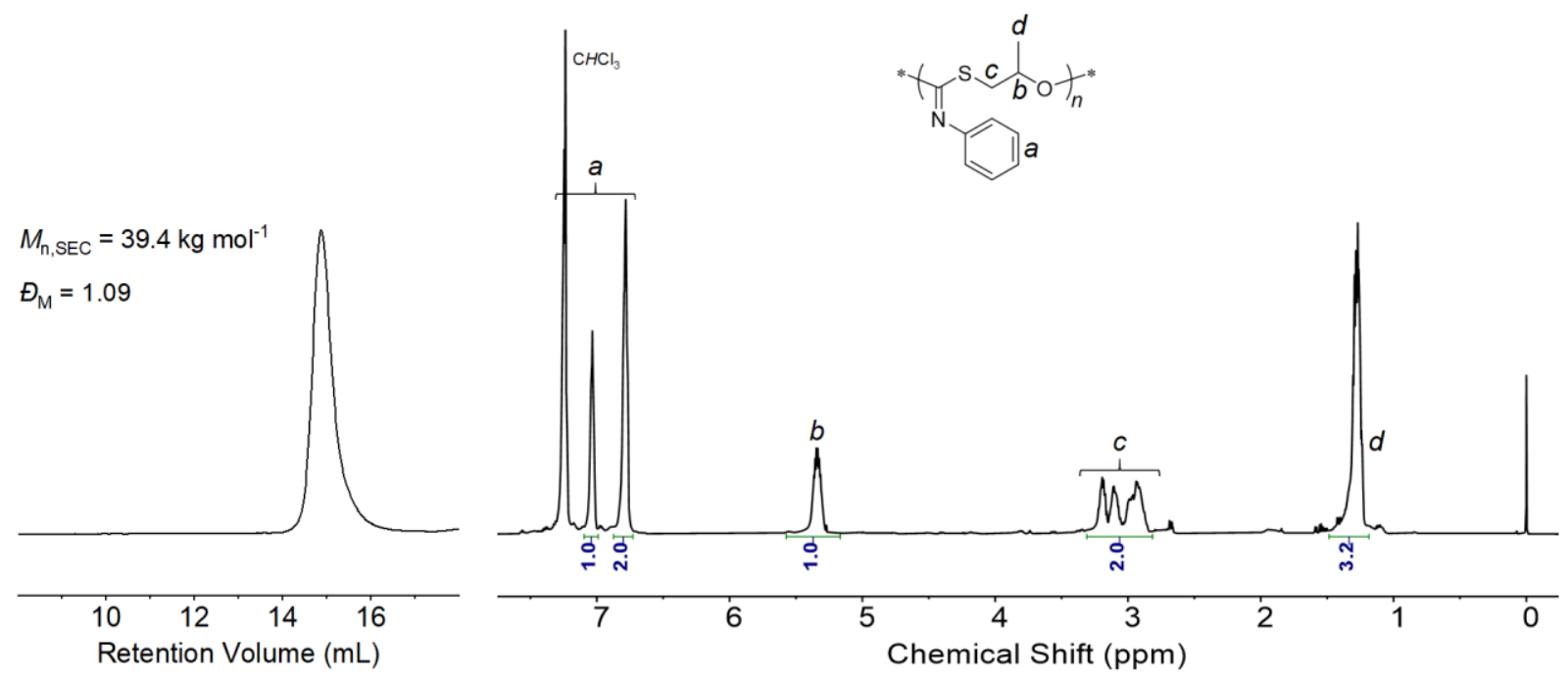

Figure S10. SEC trace (left) and ${ }^{1} \mathrm{H}$ NMR spectrum (right; in $\mathrm{CDCl}_{3}$ ) of the isolated high-molar-mass copolymer from the copolymerization of PhITC and PO catalyzed by ${ }^{t} \mathrm{BuP}_{2} / \mathrm{Et}_{3} \mathrm{~B}(1 / 0.3)$ with excess ${ }^{t} \mathrm{BuP}_{2}$ (entry 11 in Table 1 with reaction time prolonged to $66 \mathrm{~h}$ and conversion of $\mathrm{PhITC}$ increased to $94 \%)$.

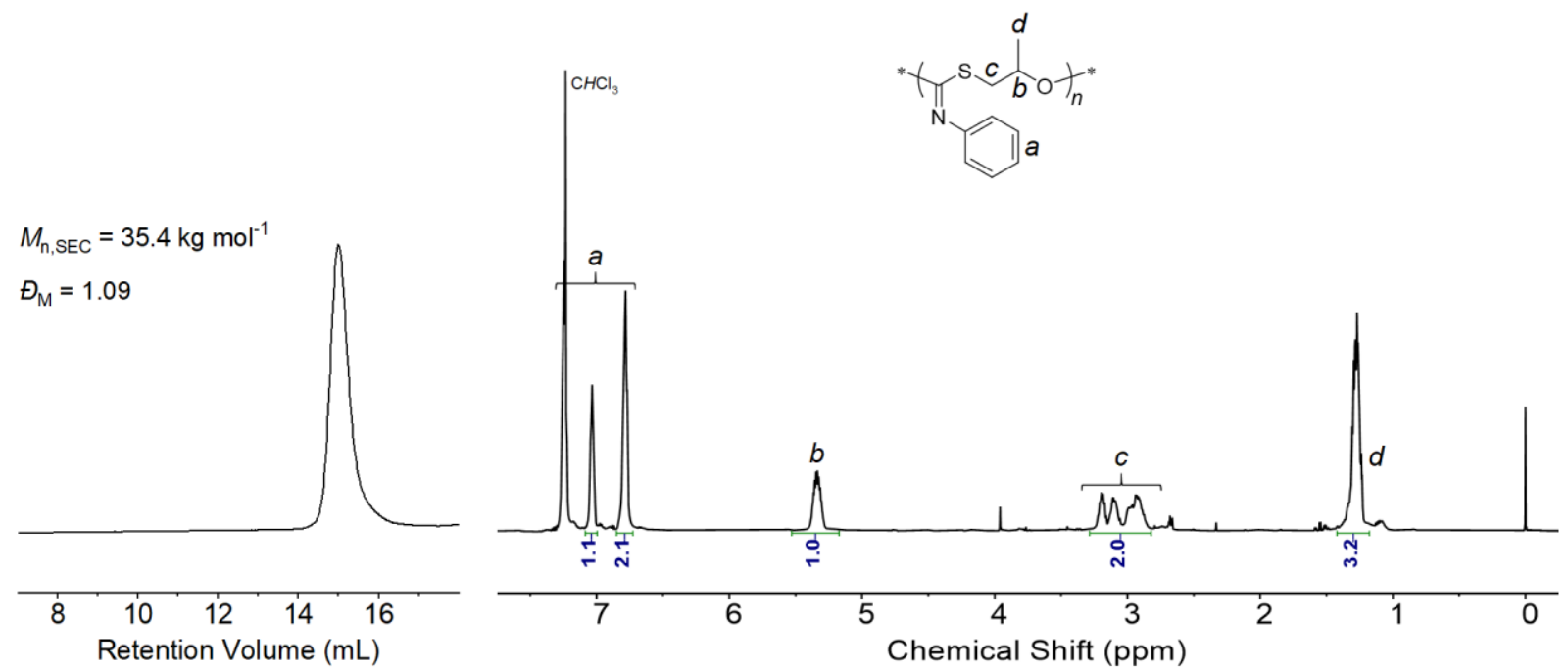

Figure S11. SEC trace (left) and ${ }^{1} \mathrm{H}$ NMR spectrum (right; in $\mathrm{CDCl}_{3}$ ) of the isolated high-molar-mass copolymer from the copolymerization of PhITC and PO catalyzed by ${ }^{t} \mathrm{BuP}_{2} / \mathrm{Et}_{3} \mathrm{~B}(1 / 0.6)$ with excess ${ }^{t} \mathrm{BuP}_{2}$ (entry 12 in Table 1 with reaction time prolonged to $90 \mathrm{~h}$ and conversion of $\mathrm{PhITC}$ increased to $90 \%)$. 

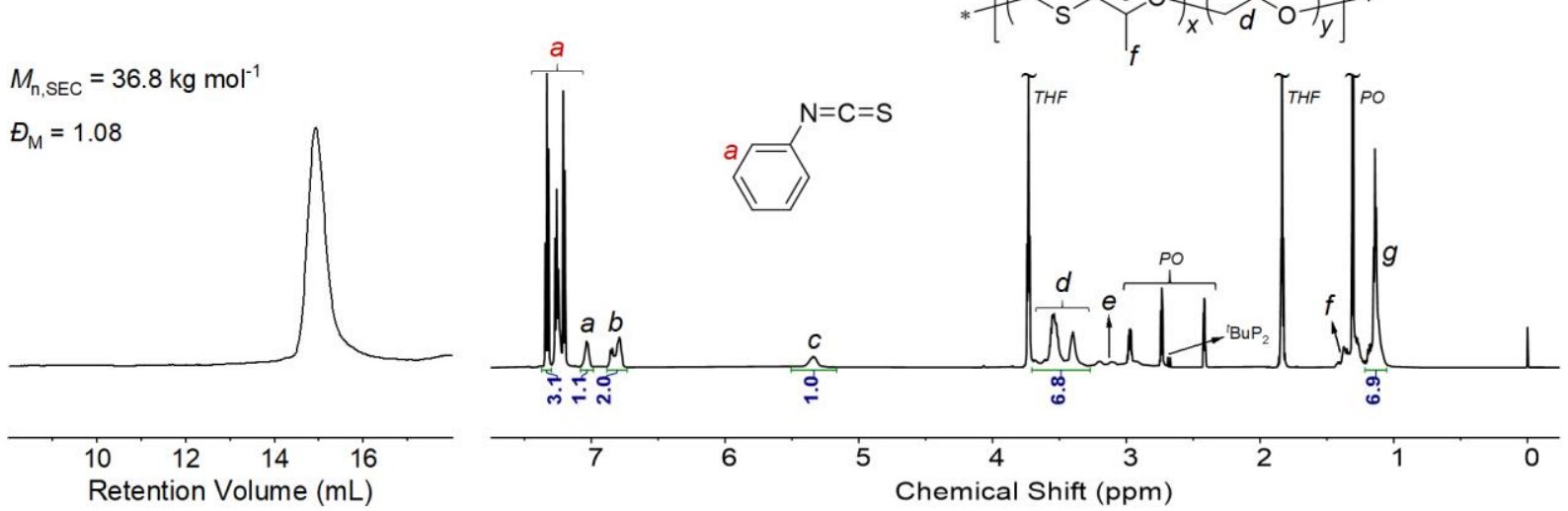

Figure S12. SEC trace (left) and ${ }^{1} \mathrm{H}$ NMR spectrum (right; in $\mathrm{CDCl}_{3}$ ) of the crude product from the copolymerization of PhITC and PO catalyzed by ${ }^{t} \mathrm{BuP}_{2} / \mathrm{Et}_{3} \mathrm{~B}(1 / 1)($ entry 13 in Table 1$) . \mathrm{EC}=I_{d} /\left(I_{c} \times 3\right.$ $\left.+I_{d}\right)=6.8 /(1.0 \times 3+6.8)=0.69$.
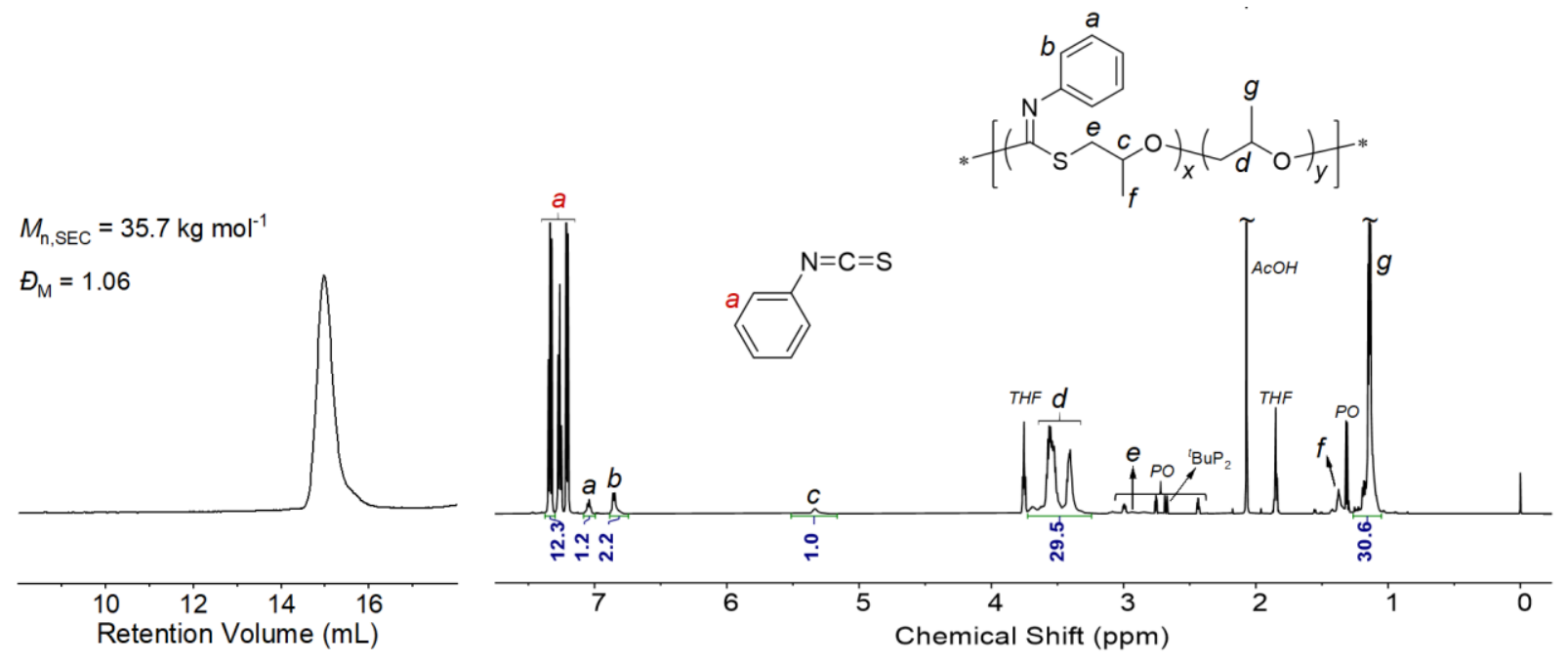

Figure S13. SEC trace (left) and ${ }^{1} \mathrm{H}$ NMR spectrum (right; in $\mathrm{CDCl}_{3}$ ) of the crude product from the copolymerization of PhITC and PO catalyzed by ${ }^{t} \mathrm{BuP}_{2} / \mathrm{Et}_{3} \mathrm{~B}$ (1/1.2) with excess $\mathrm{Et}_{3} \mathrm{~B}$ (entry 14 in Table 1). 

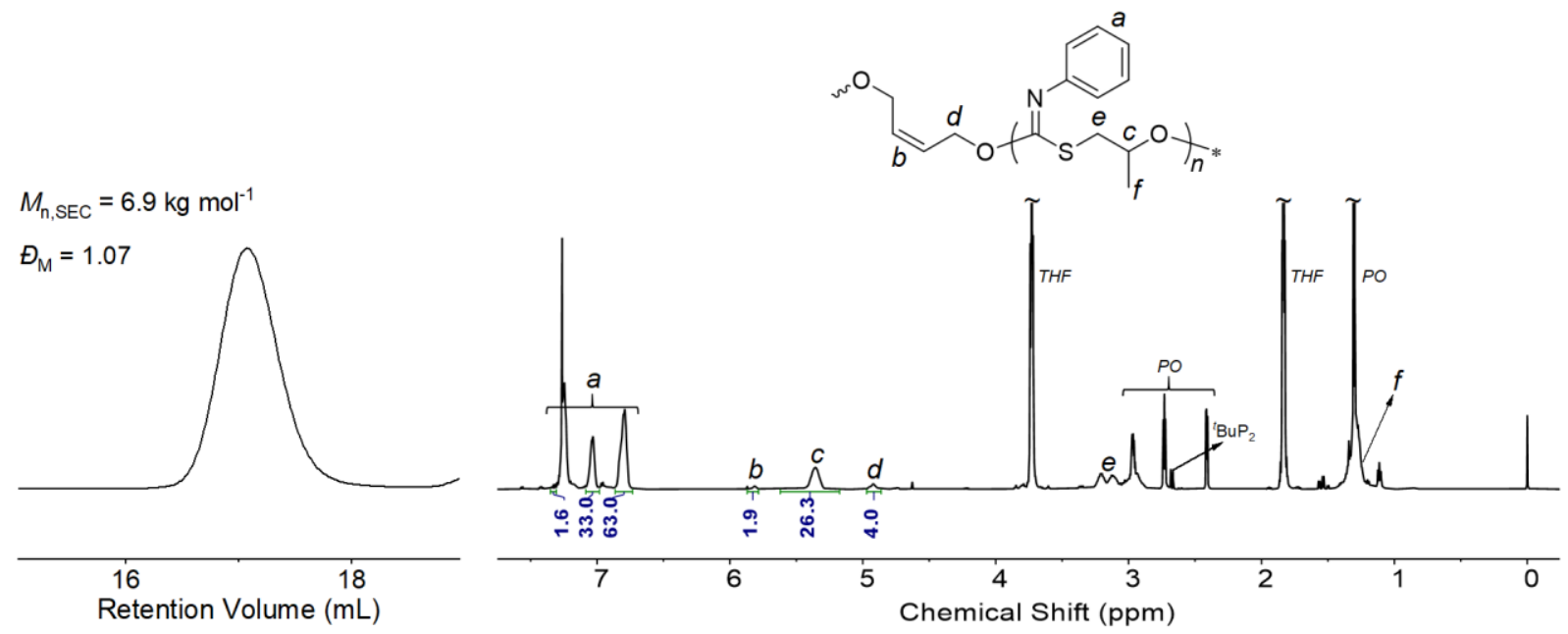

Figure S14. SEC trace (left) and ${ }^{1} \mathrm{H}$ NMR spectrum (right; in $\mathrm{CDCl}_{3}$ ) of the crude product from the copolymerization of $\mathrm{PhITC}$ and $\mathrm{PO}$ performed at $50{ }^{\circ} \mathrm{C}$ catalyzed by ${ }^{t} \mathrm{BuP}_{2} / \mathrm{Et}_{3} \mathrm{~B}$ (1/0.6) with excess ${ }^{t} \mathrm{BuP}_{2}$ (entry 15 in Table 1 ).

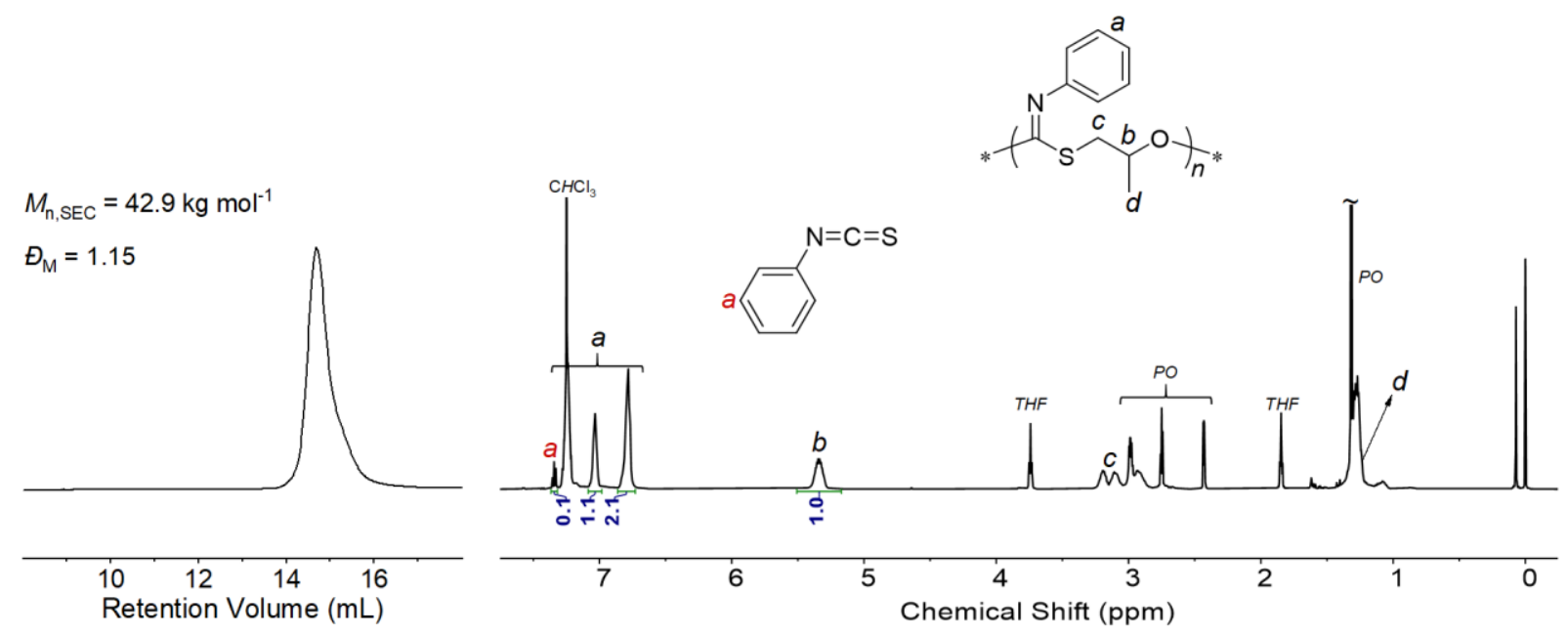

Figure S15. SEC trace (left) and ${ }^{1} \mathrm{H}$ NMR spectrum (right; in $\mathrm{CDCl}_{3}$ ) of the crude product from the copolymerization of $\mathrm{PhITC}$ and PO performed at $50{ }^{\circ} \mathrm{C}$ catalyzed by ${ }^{t} \mathrm{BuP}_{2} / \mathrm{Et}_{3} \mathrm{~B}$ (1/0.6) with excess ${ }^{t} \mathrm{BuP}_{2}$ (entry 16 in Table 1 ). 


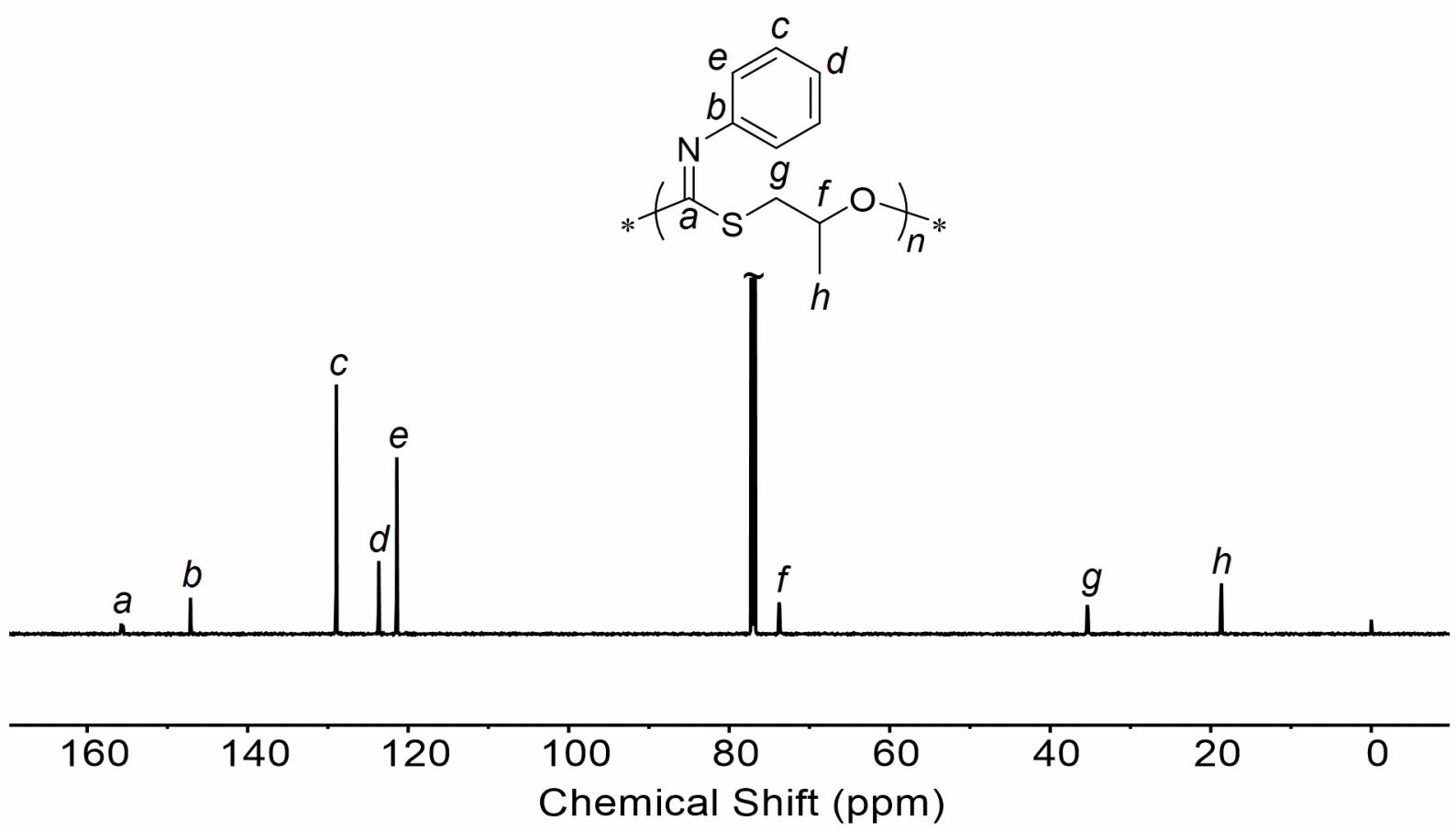

Figure S16. ${ }^{13} \mathrm{C}$ NMR spectrum (in $\mathrm{CDCl}_{3}$ ) of the isolated copolymer of PhITC and PO (entry 16 in Table 1).

(a) PhITC-Et 3 B interactions

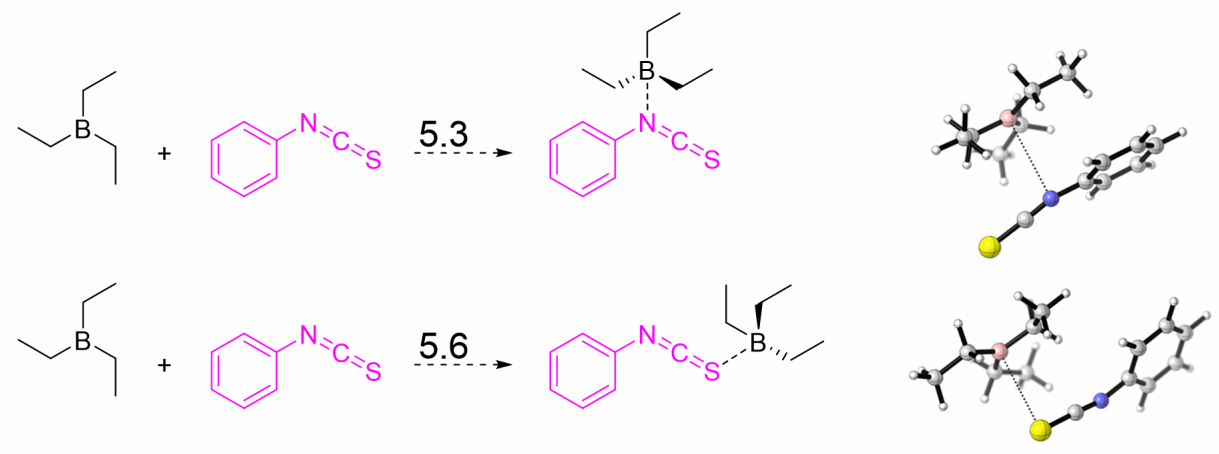

(b) $\mathrm{PO}-\mathrm{Et}_{3} \mathrm{~B}$ interaction

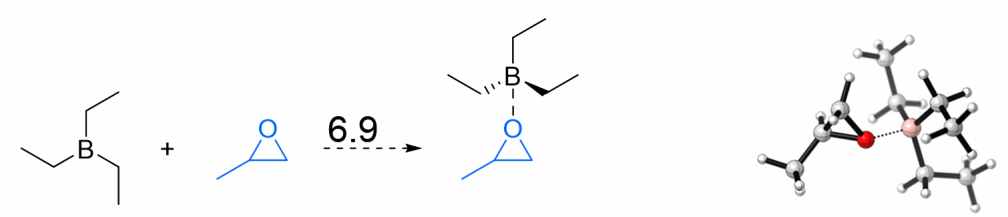

Figure S17. DFT calculations of PhITC-Et 3 B (a) and PO-Et $t_{3} B$ (b) interactions with the values of $\Delta G$ $\left(\mathrm{kcal} \mathrm{mol}^{-1}\right)$ given above the arrows. 


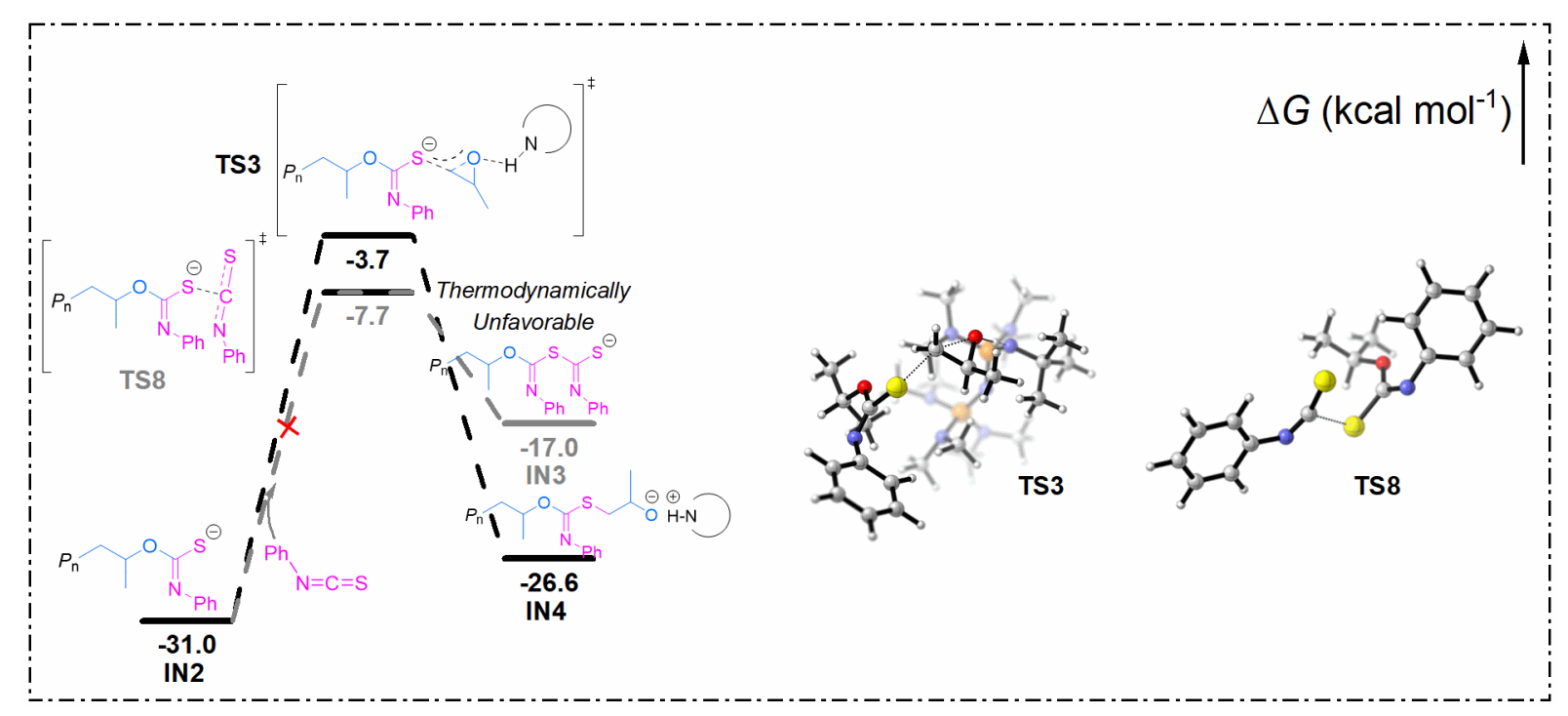

Figure S18. Supplementary DFT calculation of TS8 for Figure 2.

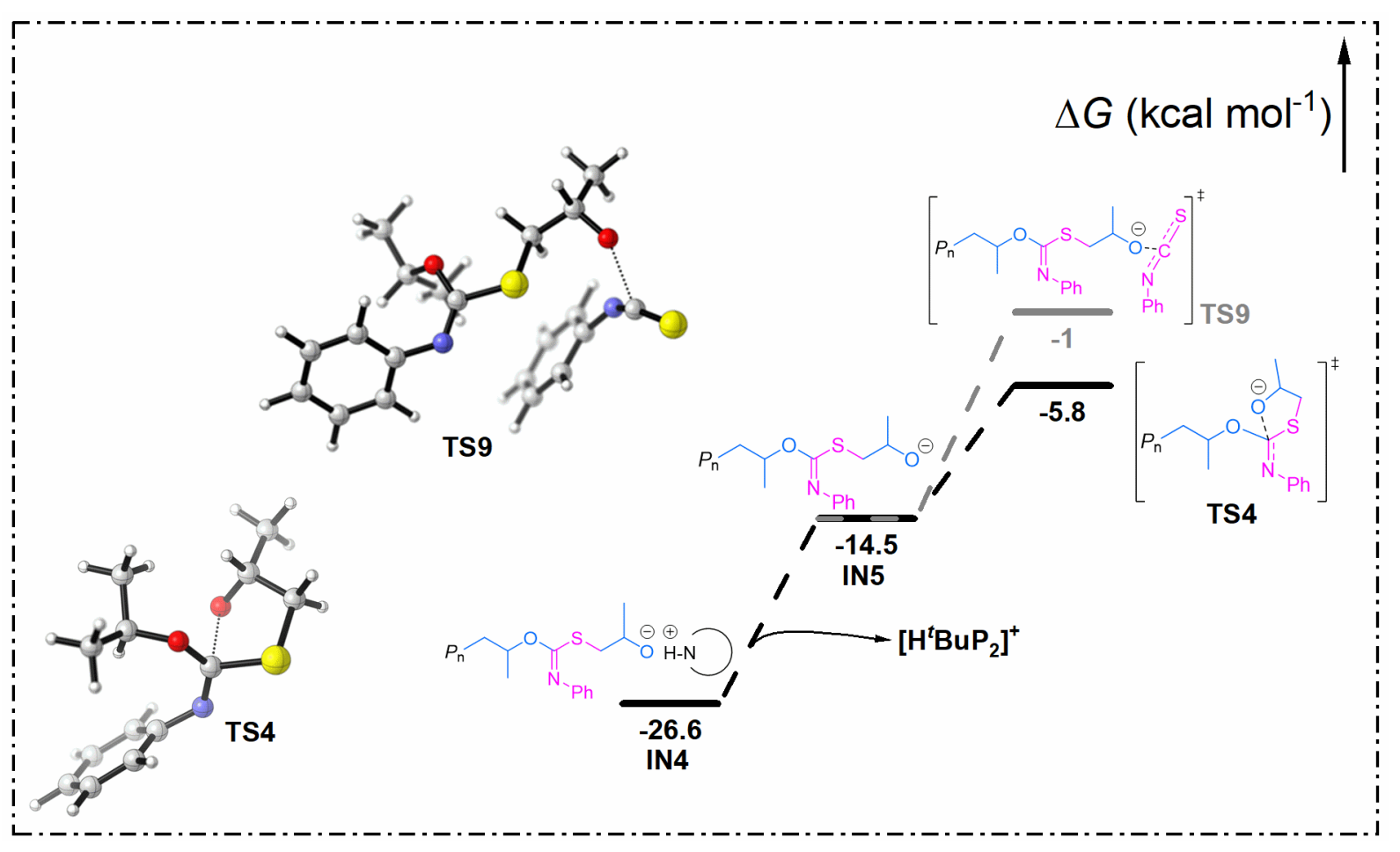

Figure S19. Supplementary DFT calculation of TS9 for Figure 2. 
(a)
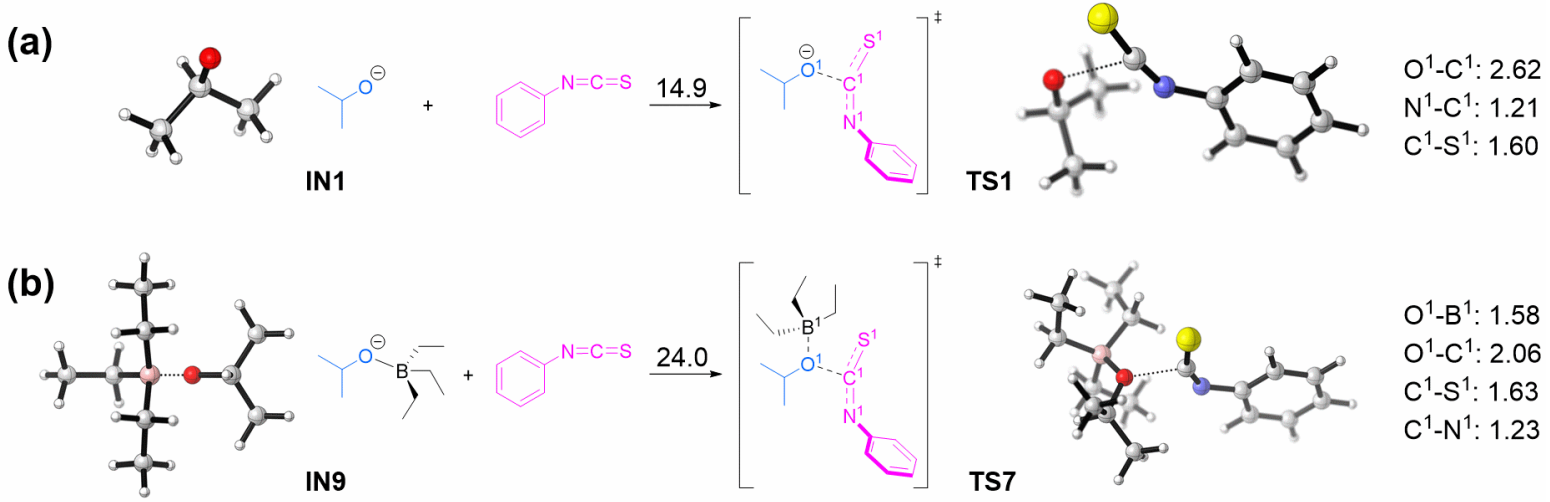

Figure S20. DFT calculations for the nucleophilic attack of PhITC by an uncapped alkoxide species (a) or a $\mathrm{Et}_{3} \mathrm{~B}$-capped alkoxide species (b) with energy barriers $\left(\Delta G / \mathrm{kcal} \mathrm{mol}^{-1}\right)$ given above the arrows. Optimized key intermediates and transition states are shown on both sides. Bond lengths ( $\mathrm{A}$ ) of the transition states are given on the right side.
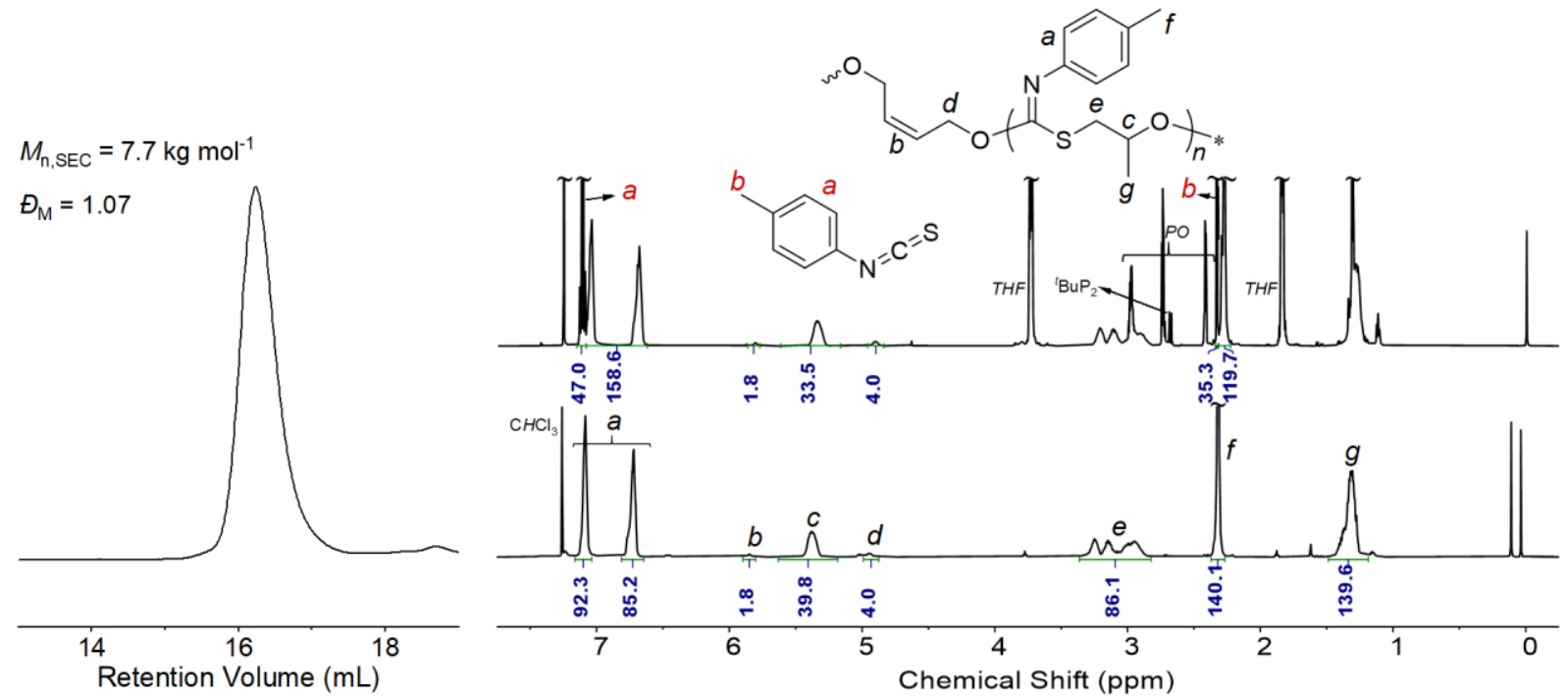

Figure S21. SEC trace (left) of the isolated copolymer and ${ }^{1} \mathrm{H}$ NMR spectra (right; in $\mathrm{CDCl}_{3}$ ) of both the crude product and the isolated copolymer from the copolymerization of TITC and PO catalyzed by ${ }^{t} \mathrm{BuP}_{2} / \mathrm{Et}_{3} \mathrm{~B}(1 / 0.6)$ with excess ${ }^{t} \mathrm{BuP}_{2}$ (entry 1 in Table 2). 

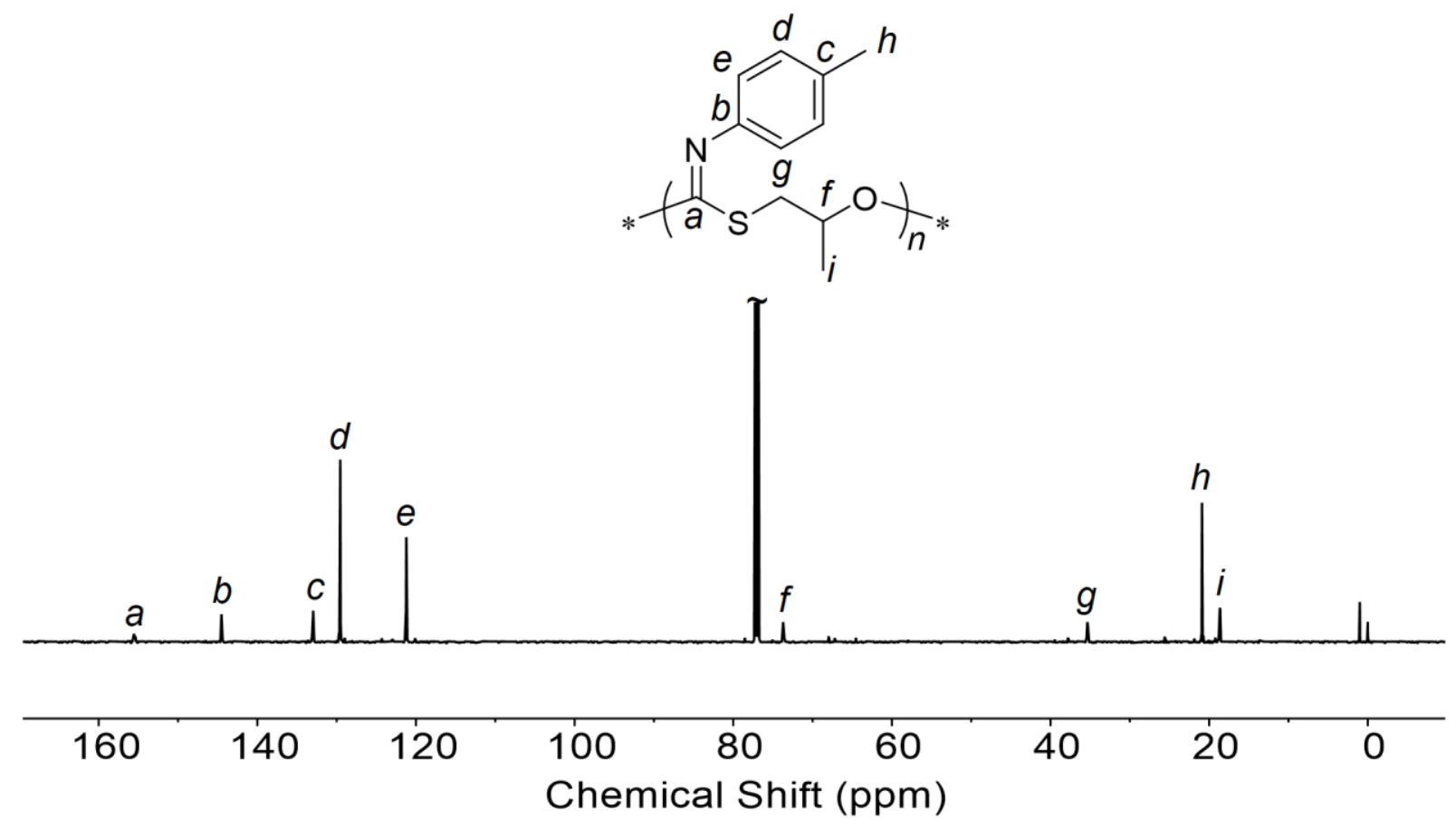

Figure S22. ${ }^{13} \mathrm{C}$ NMR spectrum (in $\mathrm{CDCl}_{3}$ ) of the isolated copolymer of TITC and PO (entry 1 in Table 2).

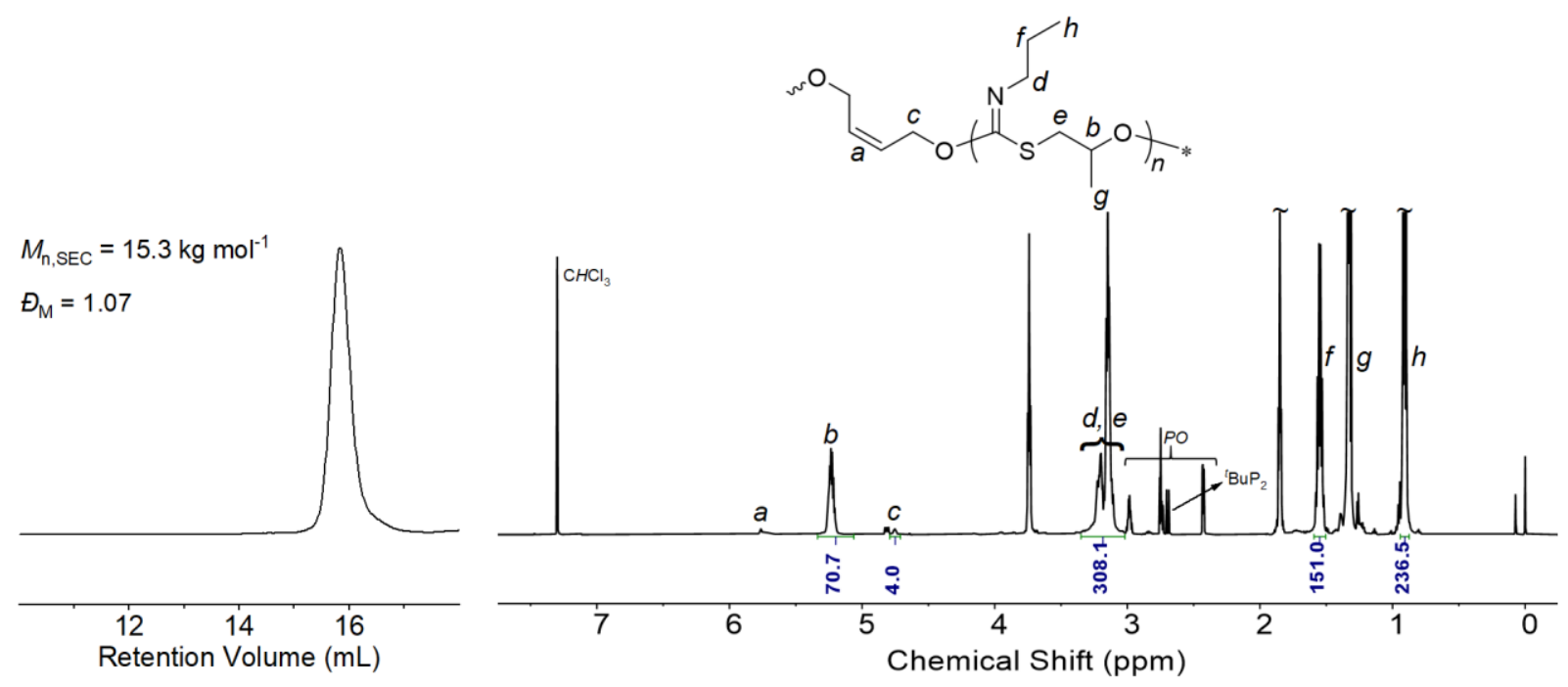

Figure S23. SEC trace (left) and ${ }^{1} \mathrm{H}$ NMR spectrum (right; in $\mathrm{CDCl}_{3}$ ) of the crude product from the copolymerization of ${ }^{n} \mathrm{PrITC}$ and PO catalyzed by ${ }^{t} \mathrm{BuP}_{2} / \mathrm{Et}_{3} \mathrm{~B}$ (1/0.6) with excess ${ }^{t} \mathrm{BuP}_{2}$ (entry 2 in Table 2). 

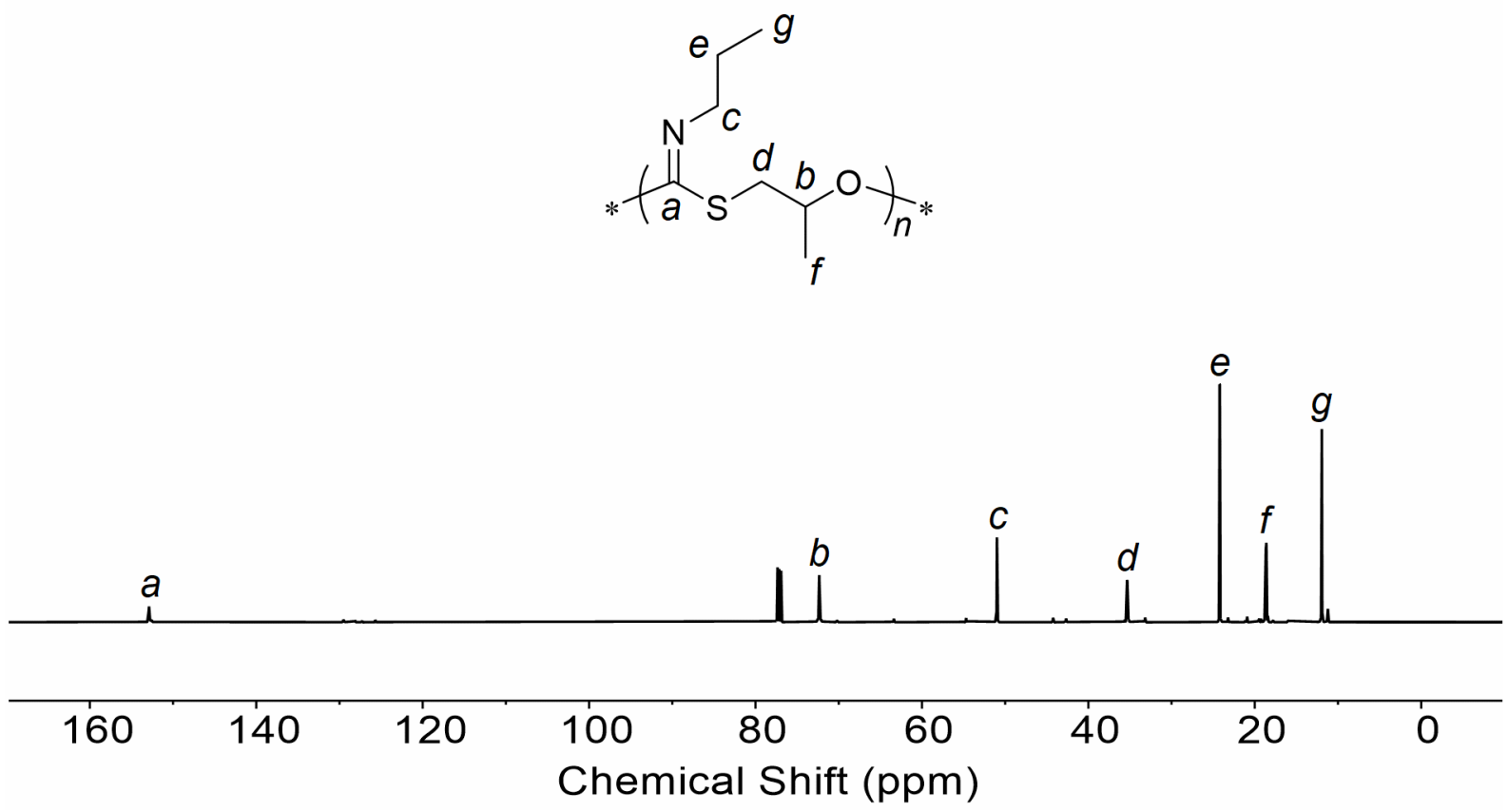

Figure S24. ${ }^{13} \mathrm{C}$ NMR spectrum (in $\mathrm{CDCl}_{3}$ ) of the isolated copolymer of ${ }^{n} \mathrm{PrITC}$ and PO (entry 2 in Table 2).

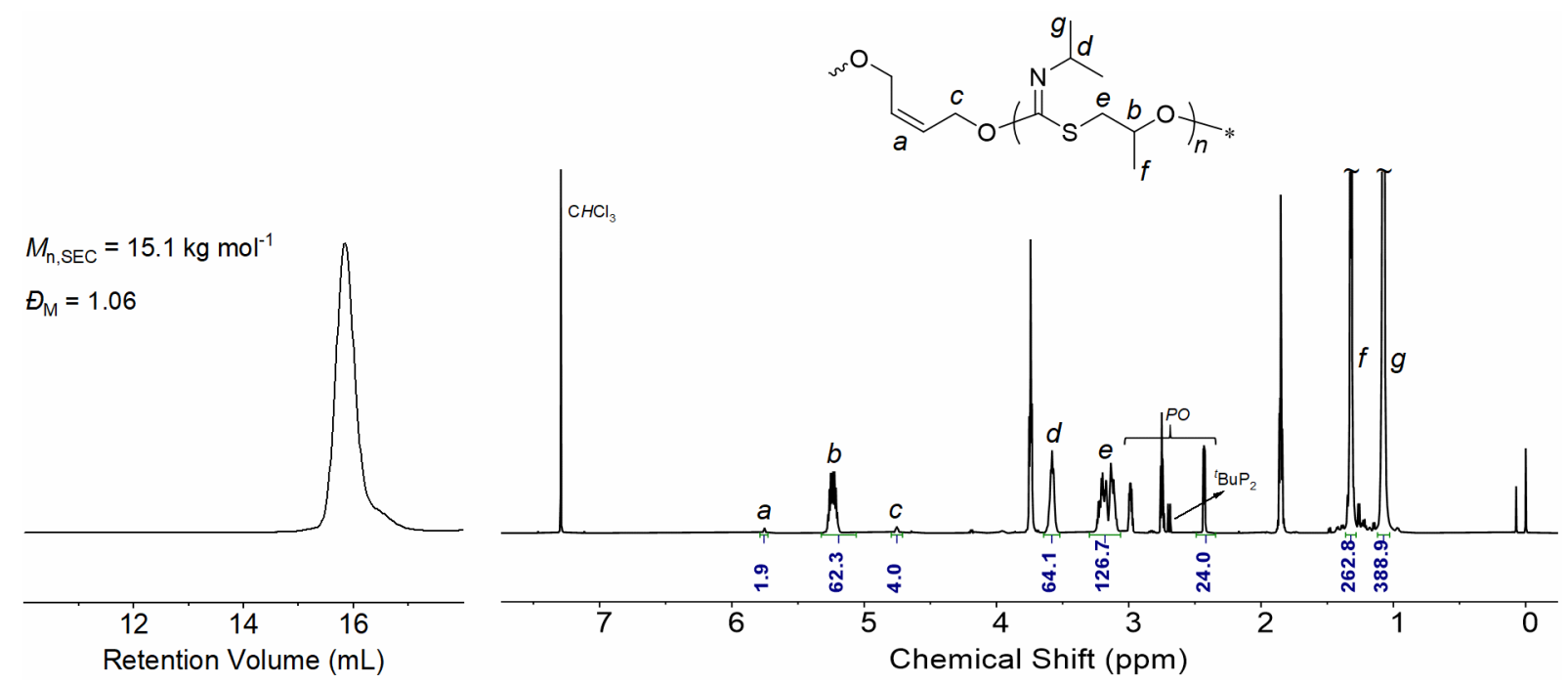

Figure S25. SEC trace (left) and ${ }^{1} \mathrm{H}$ NMR spectrum (right; in $\mathrm{CDCl}_{3}$ ) of the crude product from the copolymerization of ${ }^{i} \mathrm{PrITC}$ and $\mathrm{PO}$ catalyzed by ${ }^{t} \mathrm{BuP}_{2} / \mathrm{Et}_{3} \mathrm{~B}(1 / 0.6)$ with excess ${ }^{t} \mathrm{BuP}_{2}$ (entry 3 in Table 2). 

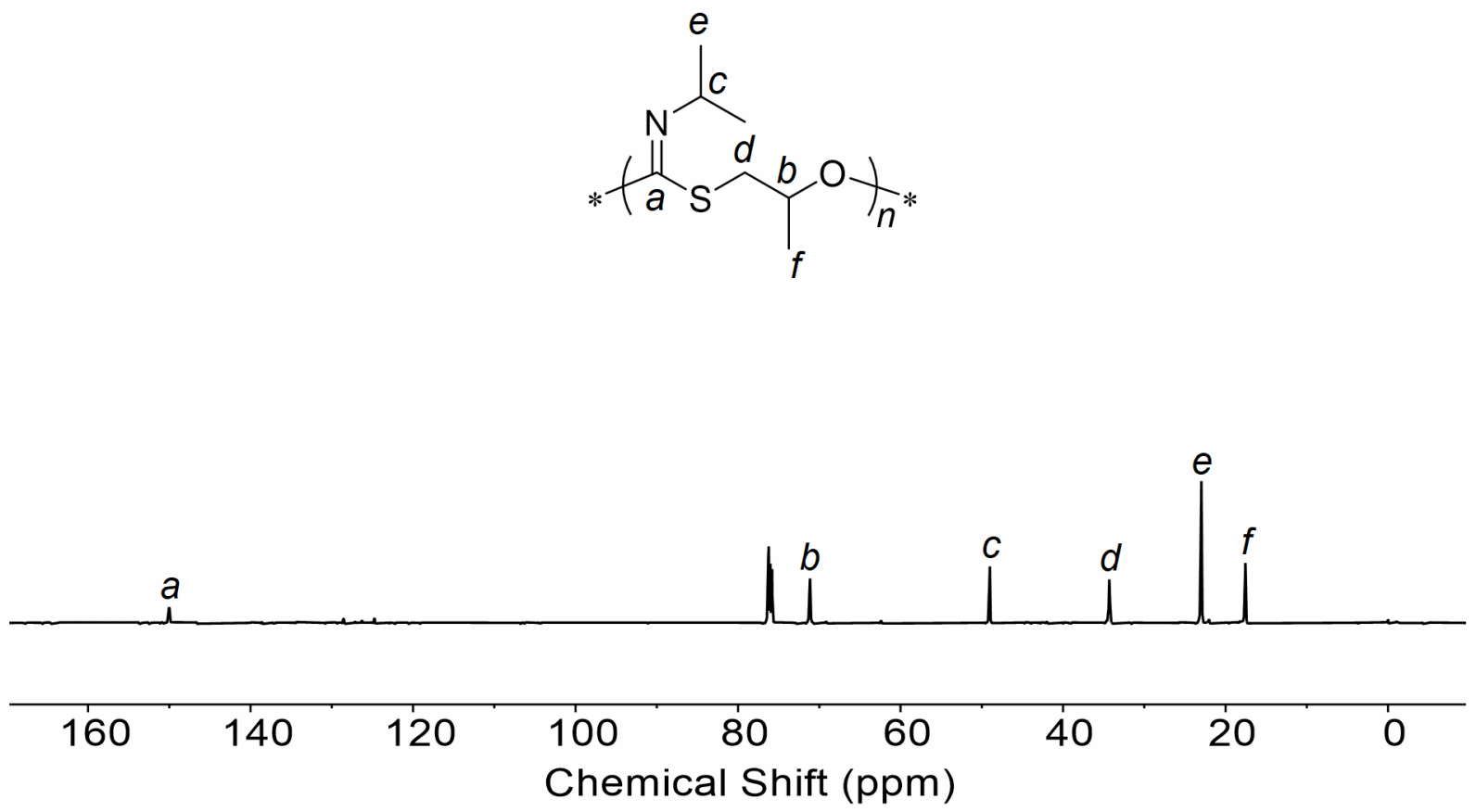

Figure S26. ${ }^{13} \mathrm{C}$ NMR spectrum (in $\mathrm{CDCl}_{3}$ ) of the isolated copolymer of ${ }^{i}$ PrITC and PO (entry 3 in Table 2).

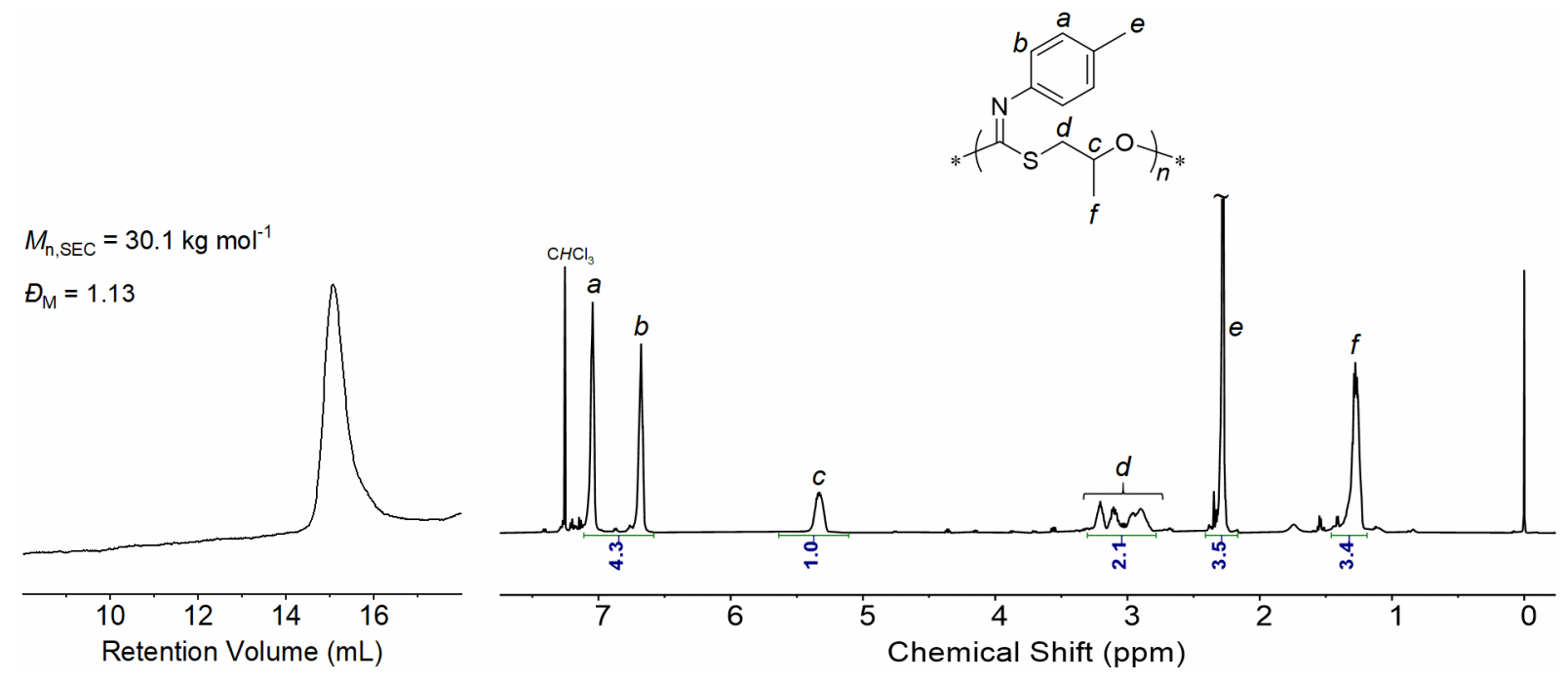

Figure S27. SEC trace (left) and ${ }^{1} \mathrm{H}$ NMR spectrum (right; in $\mathrm{CDCl}_{3}$ ) of the isolated high-molar-mass copolymer from the copolymerization of TITC and PO catalyzed by ${ }^{t} \mathrm{BuP}_{2} / \mathrm{Et}_{3} \mathrm{~B}$ (1/0.6) with excess ${ }^{t} \mathrm{BuP}_{2}$ (entry 4 in Table 2). 


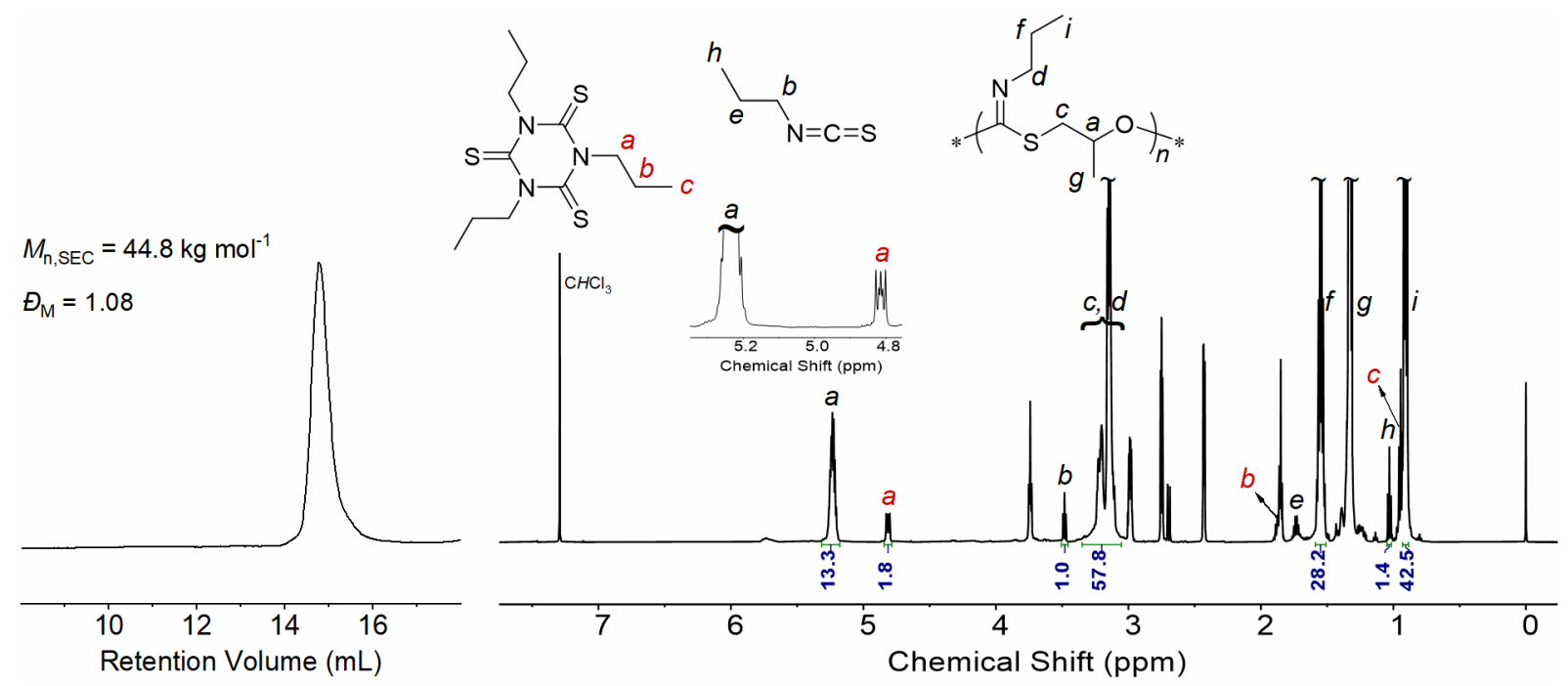

Figure S28. SEC trace (left) of the high-molar-mass copolymer and ${ }^{1} \mathrm{H}$ NMR spectrum (right; in $\mathrm{CDCl}_{3}$ ) of the crude product from the copolymerization of ${ }^{n} \mathrm{PrITC}$ and $\mathrm{PO}$ catalyzed by ${ }^{t} \mathrm{BuP}_{2} / \mathrm{Et}_{3} \mathrm{~B}$ (1/0.6) with excess ${ }^{t} \mathrm{BuP}_{2}$ (entry 5 in Table 2). Linear selectivity (LS) is calculated from the ${ }^{1} \mathrm{H}$ NMR spectrum of the crude product using integrals (I) of characteristic proton signals of the copolymer and the cyclic product as $I_{\mathrm{f}}($ black $) /\left[I_{\mathrm{a}}(\right.$ red $)+I_{\mathrm{f}}($ black $\left.)\right]=28.2 /(1.8+28.2)=0.94$.

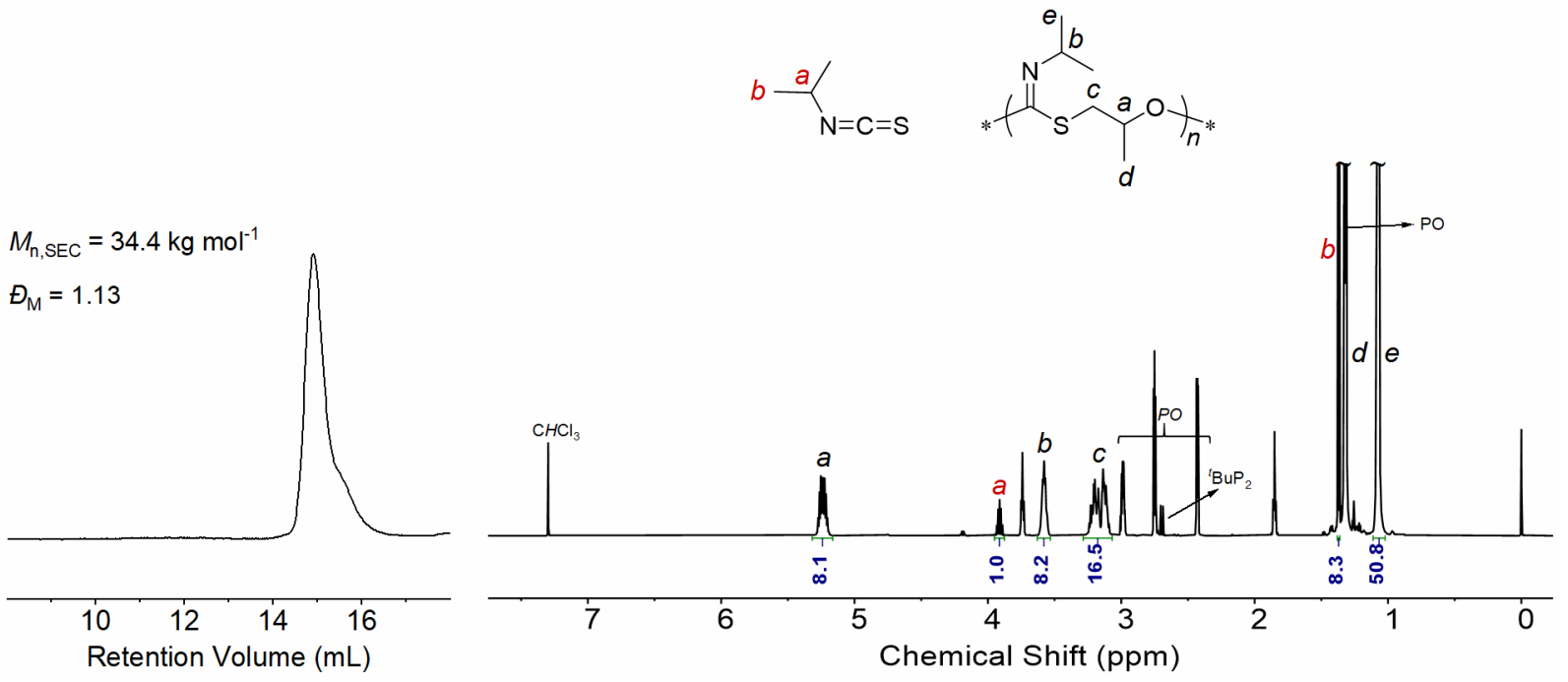

Figure S29. SEC trace (left) of the high-molar-mass copolymer and ${ }^{1} \mathrm{H}$ NMR spectrum (right; in $\mathrm{CDCl}_{3}$ ) of the crude product from the copolymerization of ${ }^{i} \mathrm{PrITC}$ and PO catalyzed by ${ }^{t} \mathrm{BuP}_{2} / \mathrm{Et}_{3} \mathrm{~B}$ (1/0.6) with excess ${ }^{t} \mathrm{BuP}_{2}$ (entry 6 in Table 2). 

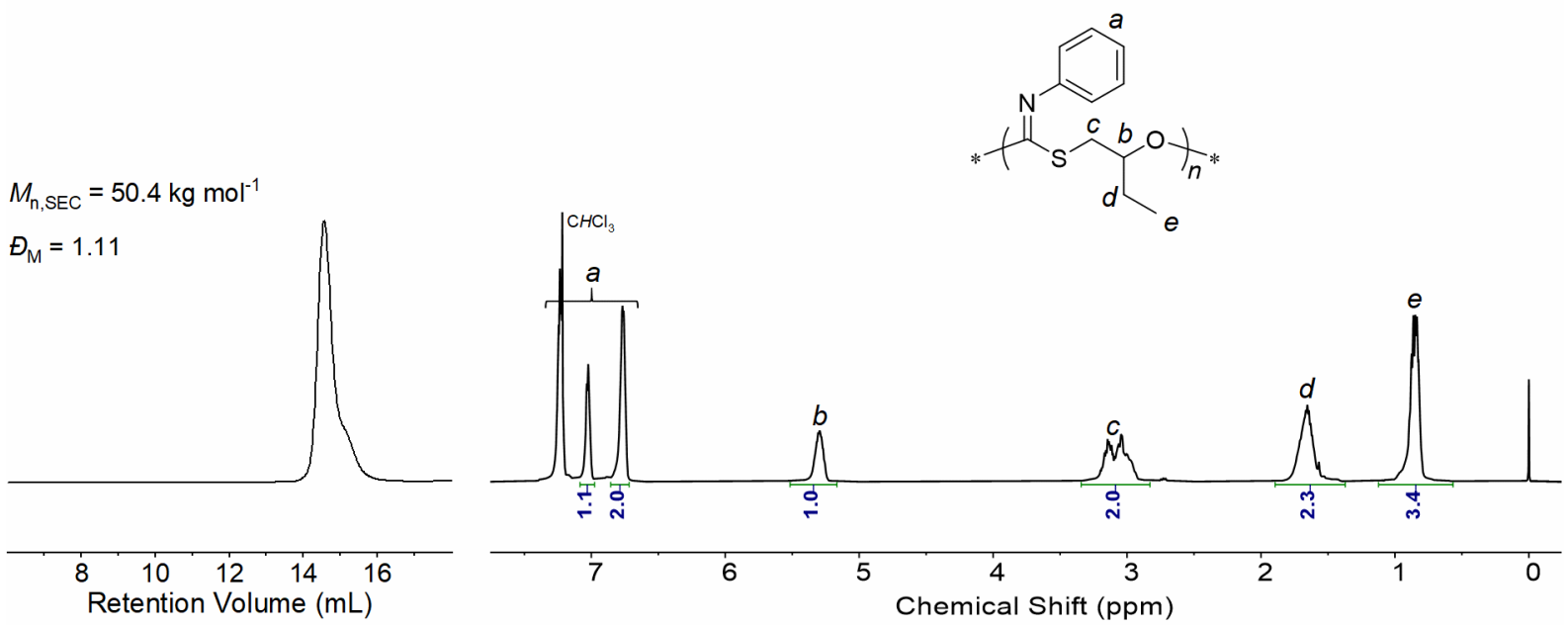

Figure S30. SEC trace (left) and ${ }^{1} \mathrm{H}$ NMR spectrum (right; in $\mathrm{CDCl}_{3}$ ) of the isolated high-molar-mass copolymer from the copolymerization of PhITC and $\mathrm{BO}$ catalyzed by ${ }^{t} \mathrm{BuP}_{2} / \mathrm{Et}_{3} \mathrm{~B}(1 / 0.6)$ with excess ${ }^{t} \mathrm{BuP}_{2}$ (entry 8 in Table 2).

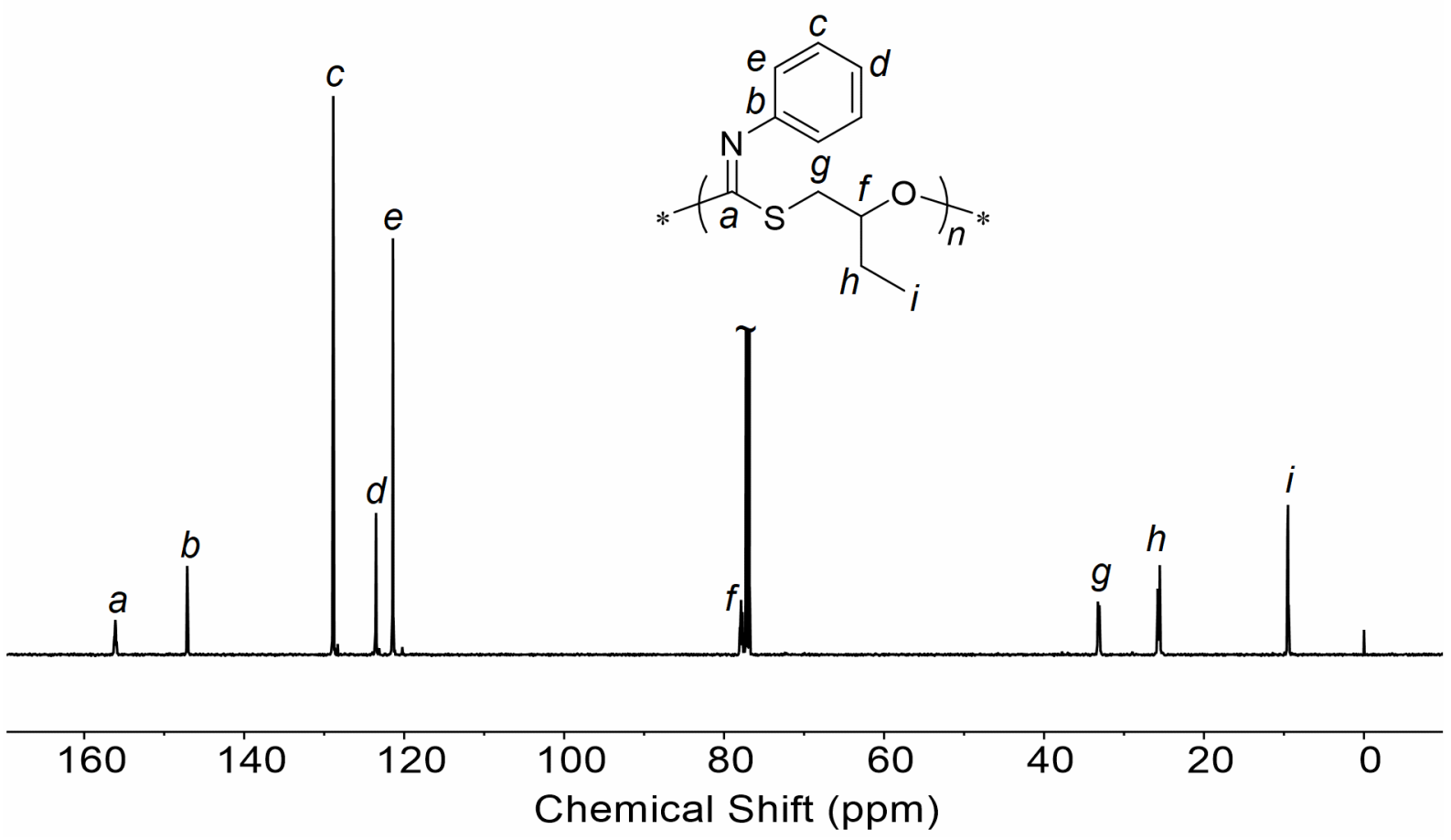

Figure S31. ${ }^{13} \mathrm{C}$ NMR spectrum (in $\mathrm{CDCl}_{3}$ ) of the isolated copolymer of PhITC and $\mathrm{BO}$ (entry 8 in Table 2). 


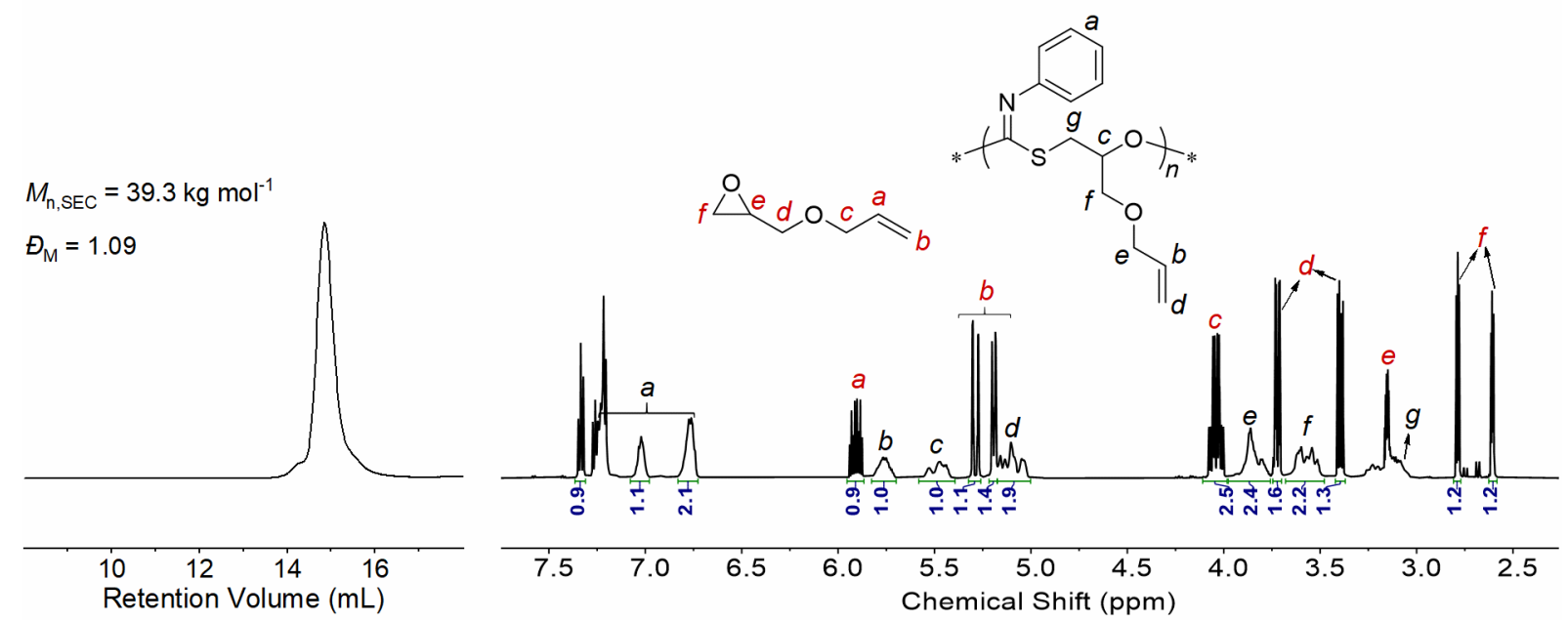

Figure S32. SEC trace (left) and ${ }^{1} \mathrm{H}$ NMR spectrum (right; in $\mathrm{CDCl}_{3}$ ) of the crude product from the copolymerization of $\mathrm{PhITC}$ and AGE catalyzed by ${ }^{t} \mathrm{BuP}_{2} / \mathrm{Et}_{3} \mathrm{~B}(1 / 0.6)$ with excess ${ }^{t} \mathrm{BuP}_{2}$ (entry 9 in Table 2).

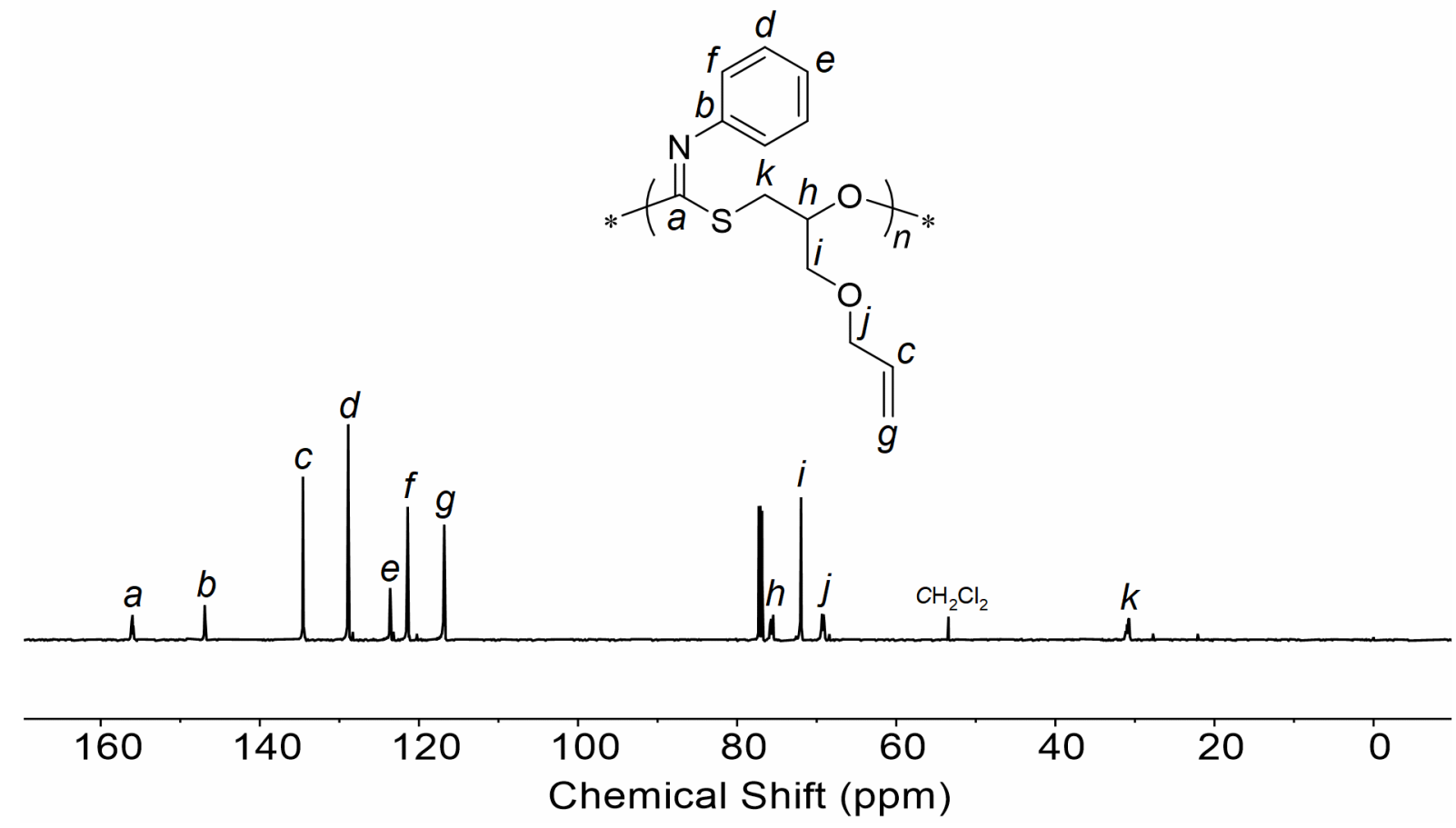

Figure S33. ${ }^{13} \mathrm{C}$ NMR spectrum (in $\mathrm{CDCl}_{3}$ ) of isolated copolymer of PhITC and AGE (entry 9 in Table 2). 

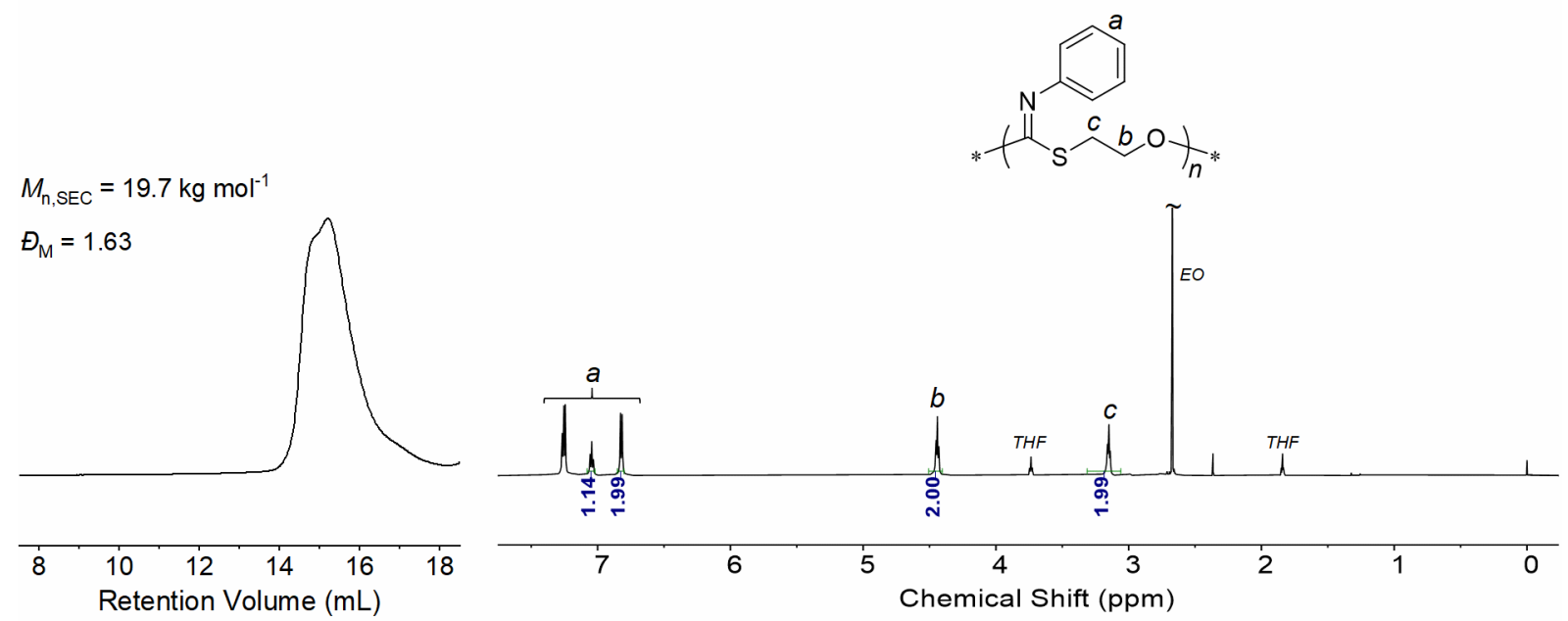

Figure S34. SEC trace (left) and ${ }^{1} \mathrm{H}$ NMR spectrum (right; in $\mathrm{CDCl}_{3}$ ) of the crude product from the copolymerization of PhITC and EO catalyzed by ${ }^{t} \mathrm{BuP}_{2} / \mathrm{Et}_{3} \mathrm{~B}(1 / 0.6)$ with excess ${ }^{t} \mathrm{BuP}_{2}$ (entry 10 in Table 2; reaction time $=12 \mathrm{~h}$ ).

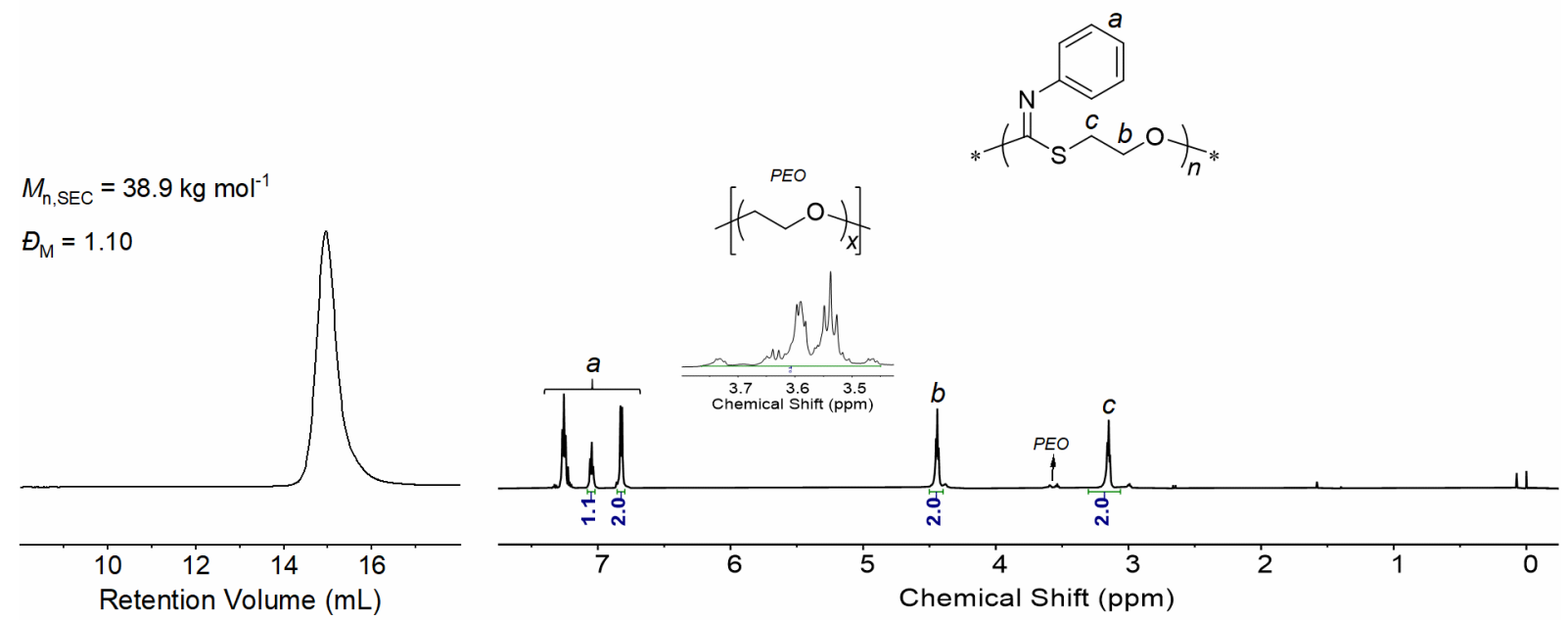

Figure S35. SEC trace (left) and ${ }^{1} \mathrm{H}$ NMR spectra (right; in $\mathrm{CDCl}_{3}$ ) of the isolated high-molar-mass copolymer from the copolymerization of PhITC and EO catalyzed by ${ }^{t} \mathrm{BuP}_{1} / \mathrm{Et}_{3} \mathrm{~B}(1 / 0.1)$ with excess ${ }^{t} \mathrm{BuP}_{1}$ (entry 11 in Table 2 ; reaction time $=96 \mathrm{~h}$ ). 

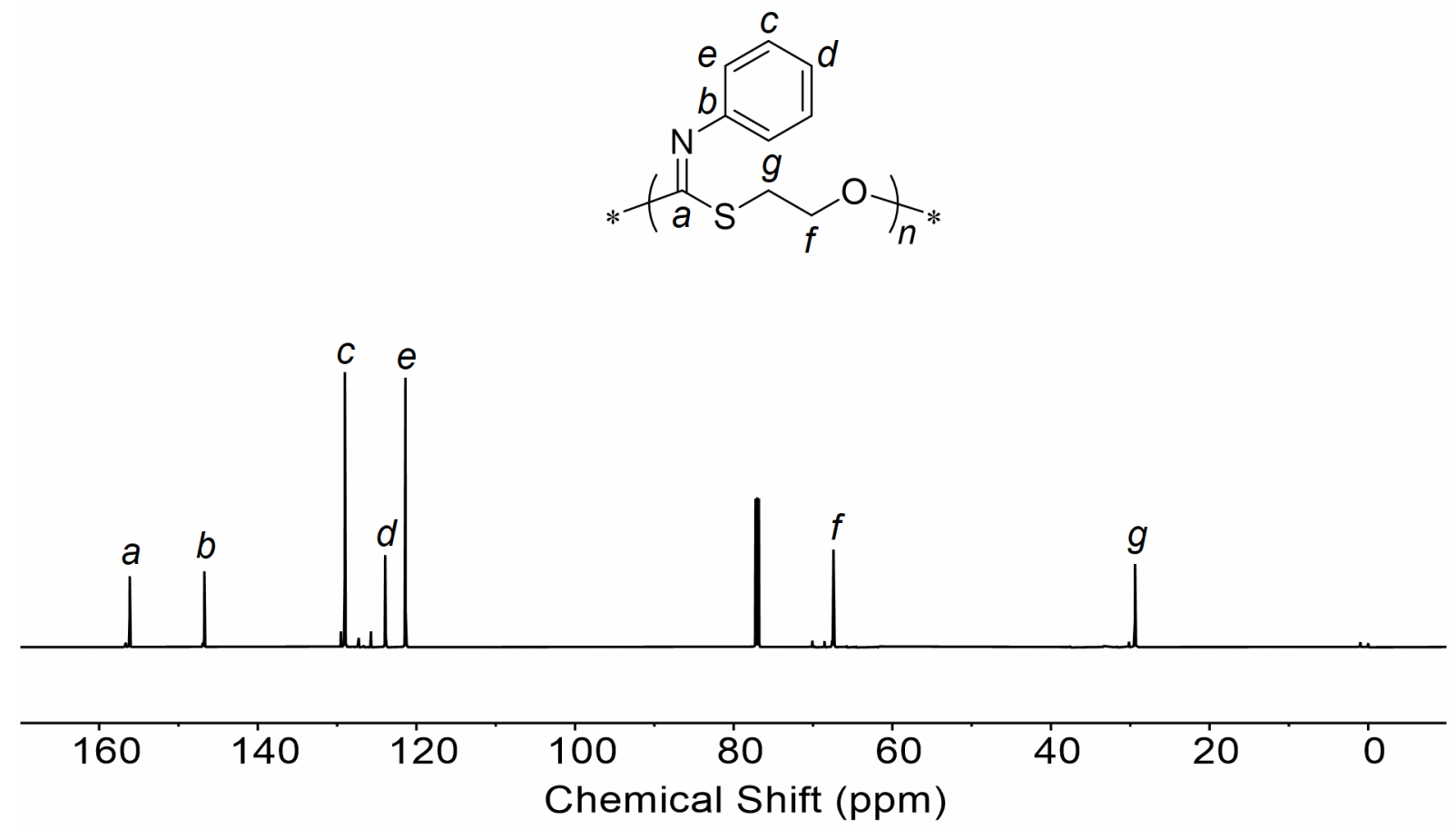

Figure S36. ${ }^{13} \mathrm{C}$ NMR spectrum (in $\mathrm{CDCl}_{3}$ ) of the isolated copolymer of PhITC and EO (entry 11 in Table 2).
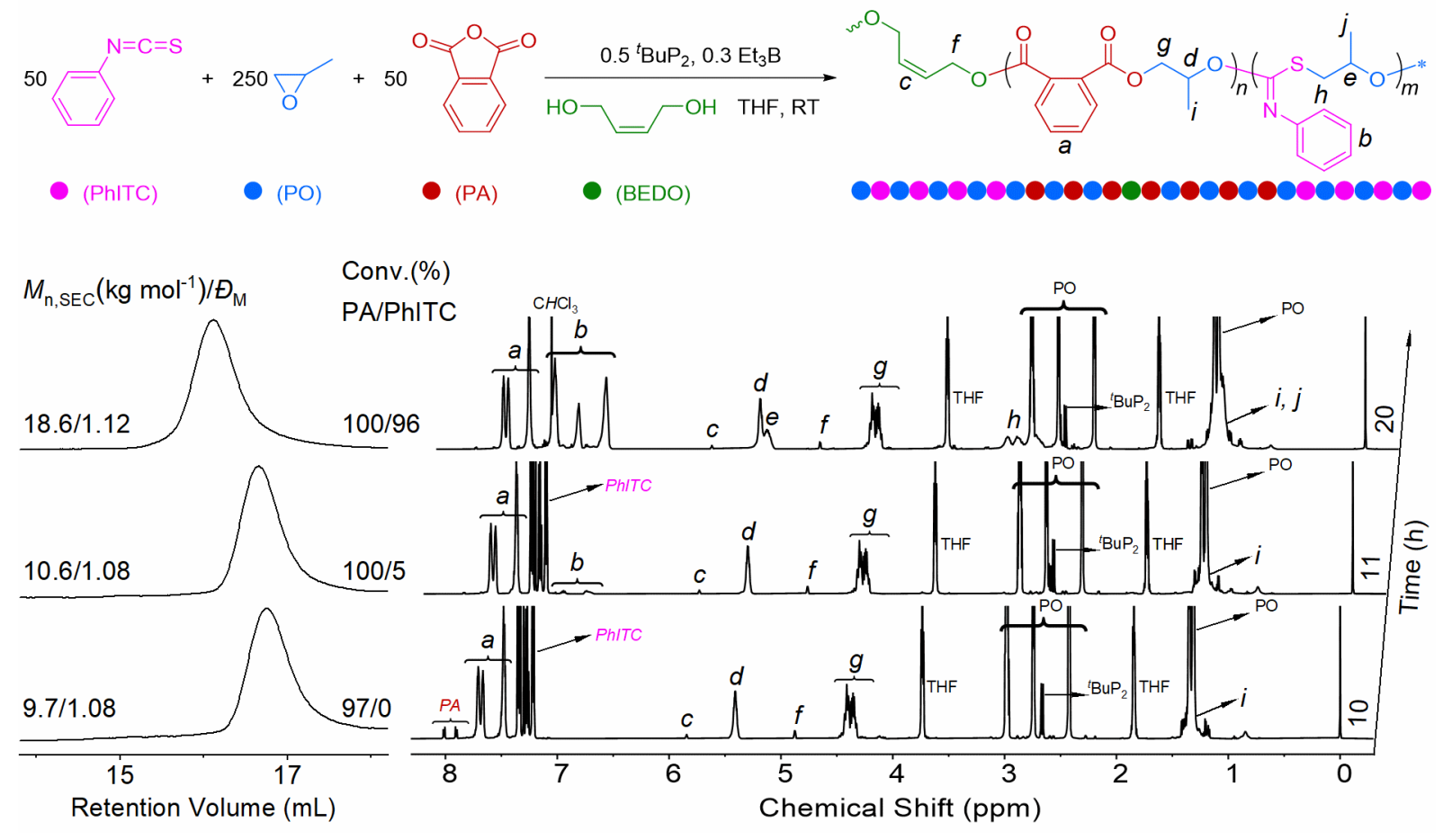

Figure S37. Schematic illustration of one-step block terpolymerization of PA/PO and PhITC/PO (top). SEC traces (bottom left) and ${ }^{1} \mathrm{H}$ NMR spectra (bottom right) of the aliquots withdrawn at the critical reaction times. The molar feed ratio of PA, PhITC, PO, BEDO, ${ }^{t} \mathrm{BuP}_{2}$, and $\mathrm{Et}_{3} \mathrm{~B}$ is 50/50/250/1/0.5/0.3. 


\section{Reference}

(1) Frisch, M. J.; Trucks, G. W.; Schlegel, H. B.; Scuseria, G. E.; Robb, M. A.; Cheeseman, J. R.; Scalmani, G.; Barone, V.; Petersson, G. A.; Nakatsuji, H.; Li, X.; Caricato, M.; Marenich, A. V.; Bloino, J.; Janesko, B. G.; Gomperts, R.; Mennucci, B.; Hratchian, H. P.; Ortiz, J. V.; Izmaylov, A. F.; Sonnenberg, J. L.; Williams; Ding, F.; Lipparini, F.; Egidi, F.; Goings, J.; Peng, B.; Petrone, A.; Henderson, T.; Ranasinghe, D.; Zakrzewski, V. G.; Gao, J.; Rega, N.; Zheng, G.; Liang, W.; Hada, M.; Ehara, M.; Toyota, K.; Fukuda, R.; Hasegawa, J.; Ishida, M.; Nakajima, T.; Honda, Y.; Kitao, O.; Nakai, H.; Vreven, T.; Throssell, K.; Montgomery Jr., J. A.; Peralta, J. E.; Ogliaro, F.; Bearpark, M. J.; Heyd, J. J.; Brothers, E. N.; Kudin, K. N.; Staroverov, V. N.; Keith, T. A.; Kobayashi, R.; Normand, J.; Raghavachari, K.; Rendell, A. P.; Burant, J. C.; Iyengar, S. S.; Tomasi, J.; Cossi, M.; Millam, J. M.; Klene, M.; Adamo, C.; Cammi, R.; Ochterski, J. W.; Martin, R. L.; Morokuma, K.; Farkas, O.; Foresman, J. B.; Fox, D. J. Gaussian 16 Rev. C.01, Wallingford, CT, 2016.

(2) Becke, A. D. Density-functional thermochemistry. III. The role of exact exchange. J. Chem. Phys. 1993, 98, 5648-5652.

(3) Lee, C.; Yang, W.; Parr, R. G. Development of the Colle-Salvetti correlation-energy formula into a functional of the electron density. Phys. Rev. B 1988, 37, 785-789.

(4) Davidson, E. R.; Feller, D. Basis set selection for molecular calculations. Chem. Rev. 1986, 86, 681-696.

(5) Hehre, W. J.; Ditchfield, R.; Pople, J. A. Self-Consistent Molecular Orbital Methods. XII. Further Extensions of Gaussian-Type Basis Sets for Use in Molecular Orbital Studies of Organic Molecules. J. Chem. Phys. 1972, 56, 2257-2261.

(6) Hariharan, P. C.; Pople, J. A. The influence of polarization functions on molecular orbital hydrogenation energies. Theor. Chim. Acta 1973, 28, 213-222.

(7) Marenich, A. V.; Cramer, C. J.; Truhlar, D. G. Universal Solvation Model Based on Solute Electron Density and on a Continuum Model of the Solvent Defined by the Bulk Dielectric Constant and Atomic Surface Tensions. J. Phys. Chem. B 2009, 113, 6378-6396.

(8) Yang, G. W.; Zhang, Y. Y.; Xie, R.; Wu, G. P. High-Activity Organocatalysts for Synthesis of Polyether via Intramolecular Ammonium Cation-Assisted $\mathrm{S}_{\mathrm{N}} 2$ Ring-Opening Polymerization. Angew. Chem. Int. Ed. 2020, 59, 16910-16917.

(9) Grimme, S.; Antony, J.; Ehrlich, S.; Krieg, H. A consistent and accurate ab initio parametrization of density functional dispersion correction (DFT-D) for the 94 elements H-Pu. J. Chem. Phys. 2010, $132,154104$.

(10) Grimme, S.; Ehrlich, S.; Goerigk, L. Effect of the damping function in dispersion corrected density functional theory. J. Comput. Chem. 2011, 32, 1456-1465.

(11) Zhao, Y.; Truhlar, D. G. Density functionals with broad applicability in chemistry. Acc. Chem. Res. 2008, 41, 157-167.

(12) Valero, R.; Costa, R.; de, P. R. M. I.; Truhlar, D. G.; Illas, F. Performance of the M06 family of exchange-correlation functionals for predicting magnetic coupling in organic and inorganic molecules.

J. Chem. Phys. 2008, 128, 114103.

(13) Fukui, K. The path of chemical reactions-the IRC approach. Acc. Chem. Res. 1981, 14, 363-368.

(14) Legault, C. Y. CYLView. CYLView 2009, 1.0b, http://www.cylview.org.

(15) Schwesinger, R.; Schlemper, H. Peralkylated Polyaminophosphazenes - Extremely Strong, Neutral Nitrogen Bases. Angew. Chem. Int. Ed. 1987, 26, 1167-1169.

(16) Tshepelevitsh, S.; Kutt, A.; Lokov, M.; Kaljurand, I.; Saame, J.; Heering, A.; Plieger, P. G.; 
Vianello, R.; Leito, I. On the Basicity of Organic Bases in Different Media. Eur J. Org. Chem. 2019, 2019, 6735-6748.

(17) Schwesinger, R.; Schlemper, H.; Hasenfratz, C.; Willaredt, J.; Dambacher, T.; Breuer, T.; Ottaway, C.; Fletschinger, M.; Boele, J.; Fritz, H.; Putzas, D.; Rotter, H. W.; Bordwell, F. G.; Satish, A. V.; Ji, G. Z.; Peters, E. M.; Peters, K.; vonSchnering, H. G.; Walz, L. Extremely Strong, Uncharged Auxiliary Bases; Monomeric and Polymer-Supported Polyaminophosphazenes $\left(\mathrm{P}_{2}-\mathrm{P}_{5}\right)$. Liebigs Ann. 1996, 1996, 1055-1081.

\section{Optimized Geometries}

IN1

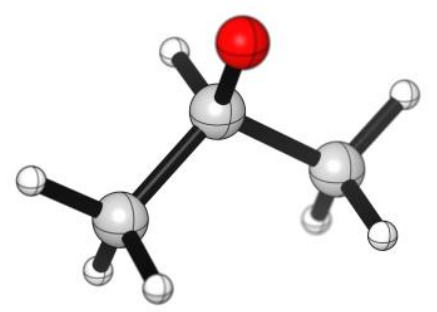

$\mathrm{C}$

$-0.21681700 \quad 0.30141500 \quad 0.00000000$

$\mathrm{H}$

$-1.23720600$

0.79245000

0.00000000

C

$-0.21681700$

$-0.60801900$

1.25875500

$\mathrm{H}$

$\begin{array}{lll}-0.26492100 & 0.00954600 & 2.16634300\end{array}$

$\mathrm{H}$

$-1.06269100 \quad-1.31484500$

1.27924900

$\mathrm{H}$

0.71838000

$-1.18775900$

1.29869000

C

$-0.21681700 \quad-0.60801900 \quad-1.25875500$

$\mathrm{H}$

$\begin{array}{lll}-1.06269100 & -1.31484500 & -1.27924900\end{array}$

$\mathrm{H}$

$-0.26492100 \quad 0.00954600$

$-2.16634300$

$\mathrm{H}$

$0.71838000 \quad-1.18775900 \quad-1.29869000$

$\mathrm{O}$

$\begin{array}{lll}0.79479800 & 1.21017500 & 0.00000000\end{array}$ 


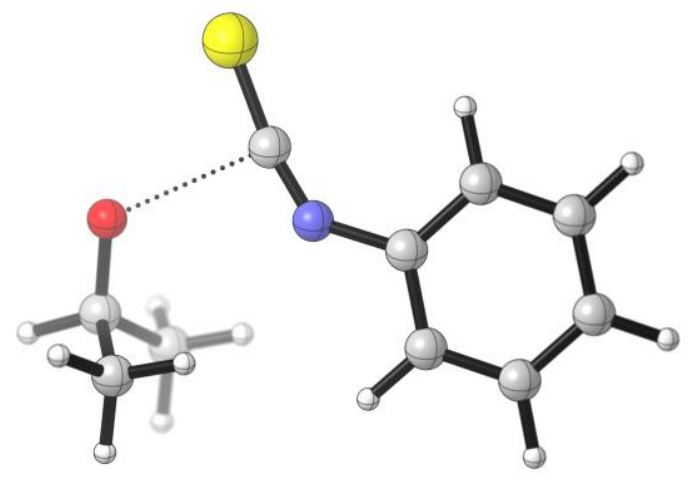

imaginary frequency $=135.11 i \mathrm{~cm}^{-1}$

$\begin{array}{llll}\mathrm{C} & -2.50723100 & -1.89640900 & 1.16809800 \\ \mathrm{H} & -1.44521000 & -1.64561400 & 1.28740600 \\ \mathrm{H} & -3.03350600 & -1.56324700 & 2.07332400 \\ \mathrm{C} & -3.08890000 & -1.16671800 & -0.07328800 \\ \mathrm{H} & -4.15996100 & -1.51871500 & -0.14126500 \\ \mathrm{O} & -3.00499900 & 0.19196800 & 0.02517700 \\ \mathrm{C} & -2.40653200 & -1.71842700 & -1.35493300 \\ \mathrm{H} & -1.33790900 & -1.46771600 & -1.35085300 \\ \mathrm{H} & -2.50773500 & -2.81147700 & -1.45522000 \\ \mathrm{H} & -2.85648900 & -1.25128500 & -2.24190600 \\ \mathrm{H} & -2.60111700 & -2.99274800 & 1.10210700 \\ \mathrm{C} & -0.65088100 & 1.34999900 & 0.07501400 \\ \mathrm{~N} & 0.02888800 & 0.35114700 & 0.10763900 \\ \mathrm{~S} & -1.29011600 & 2.81240400 & 0.05008000 \\ \mathrm{C} & 1.38216000 & 0.01498300 & 0.05644300\end{array}$




$\begin{array}{lrrr}\text { C } & 1.74252700 & -1.33726700 & 0.15231200 \\ \mathrm{C} & 2.37443400 & 1.00005100 & -0.09304000 \\ \mathrm{C} & 3.08935800 & -1.70063600 & 0.10093400 \\ \mathrm{H} & 0.96530900 & -2.08645700 & 0.26626200 \\ \mathrm{C} & 3.71687200 & 0.62423100 & -0.14368800 \\ \mathrm{H} & 2.08748500 & 2.04496600 & -0.16798900 \\ \mathrm{C} & 4.08083900 & -0.72446600 & -0.04734100 \\ \mathrm{H} & 3.36352000 & -2.74963100 & 0.17610500 \\ \mathrm{H} & 4.48113900 & 1.38861400 & -0.25932400 \\ \mathrm{H} & 5.12822700 & -1.01098600 & -0.08786800\end{array}$

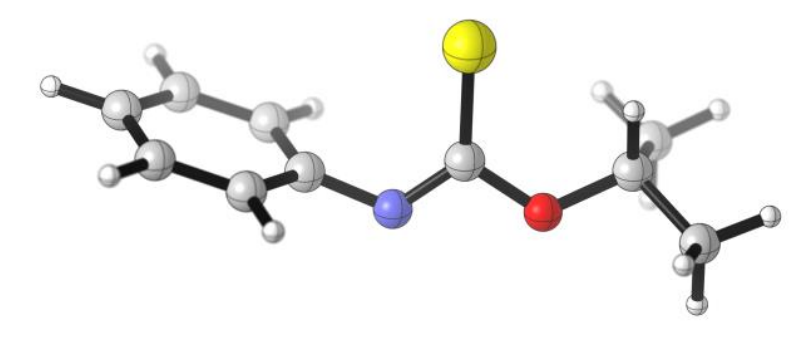

IN2

$\begin{array}{llrr}\mathrm{C} & 1.37055838 & 0.41455161 & 0.00000000 \\ \mathrm{H} & 1.25783838 & 0.55633761 & 1.07801800 \\ \mathrm{C} & 2.42458438 & -0.64743139 & -0.28058600 \\ \mathrm{H} & 2.16670338 & -1.59110539 & 0.21409700 \\ \mathrm{H} & 2.51811138 & -0.83372039 & -1.35795400 \\ \mathrm{H} & 3.39909938 & -0.31490339 & 0.09668500\end{array}$




\begin{tabular}{|c|c|c|c|}
\hline $\mathrm{C}$ & 1.68395738 & 1.75040661 & -0.66556000 \\
\hline $\mathrm{H}$ & 1.78517938 & 1.62686161 & -1.75127000 \\
\hline $\mathrm{H}$ & 0.88832738 & 2.47687161 & -0.46788000 \\
\hline $\mathrm{H}$ & 2.62467838 & 2.15753561 & -0.27395300 \\
\hline $\mathrm{O}$ & 0.12630438 & -0.10620439 & -0.51930300 \\
\hline $\mathrm{C}$ & -1.09533062 & 0.27576861 & -0.01773100 \\
\hline S & -1.21692662 & 1.07176461 & 1.53149200 \\
\hline $\mathrm{N}$ & -2.06367762 & -0.07857339 & -0.80778200 \\
\hline $\mathrm{C}$ & -3.40300662 & 0.17496461 & -0.49083100 \\
\hline $\mathrm{C}$ & -4.22090662 & -0.85037139 & 0.02129500 \\
\hline $\mathrm{C}$ & -3.99881062 & 1.41694461 & -0.78698500 \\
\hline $\mathrm{C}$ & -5.58364862 & -0.63517039 & 0.24607800 \\
\hline $\mathrm{H}$ & -3.77300462 & -1.81659439 & 0.24149900 \\
\hline $\mathrm{C}$ & -5.36123262 & 1.62783061 & -0.56444600 \\
\hline $\mathrm{H}$ & -3.37844962 & 2.21217061 & -1.19272700 \\
\hline $\mathrm{C}$ & -6.16444062 & 0.60481261 & -0.04427900 \\
\hline $\mathrm{H}$ & -6.19417962 & -1.44168339 & 0.64673900 \\
\hline $\mathrm{H}$ & -5.79856662 & 2.59602361 & -0.79946600 \\
\hline $\mathrm{H}$ & -7.22542662 & 0.76993361 & 0.12560700 \\
\hline
\end{tabular}




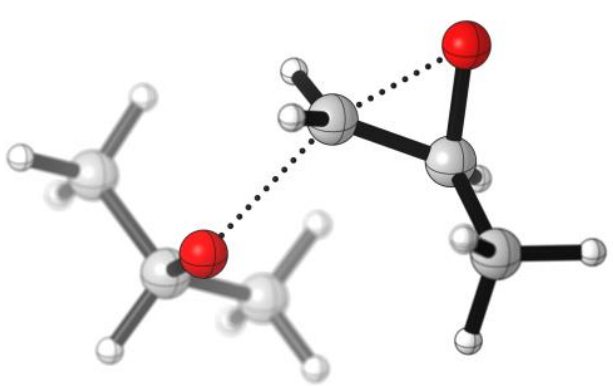

\section{TS2}

imaginary frequency $=530.69 i \mathrm{~cm}^{-1}$

\begin{tabular}{|c|c|c|c|}
\hline $\mathrm{C}$ & -1.79704700 & 0.07838500 & -0.41317700 \\
\hline $\mathrm{C}$ & -0.86360500 & -0.86918500 & 0.18146300 \\
\hline $\mathrm{O}$ & -2.45527800 & -1.15723000 & -0.57405700 \\
\hline $\mathrm{H}$ & -1.46516200 & 0.53323300 & -1.35999200 \\
\hline $\mathrm{H}$ & -1.01726000 & -1.18824900 & 1.19999600 \\
\hline $\mathrm{H}$ & -0.19264500 & -1.42885200 & -0.44958600 \\
\hline $\mathrm{C}$ & 1.97319600 & 0.34237800 & 0.34280300 \\
\hline $\mathrm{H}$ & 2.71410100 & 0.94920800 & 0.92567000 \\
\hline $\mathrm{C}$ & 2.72572700 & -0.94868300 & -0.06394800 \\
\hline $\mathrm{H}$ & 2.97621000 & -1.53300400 & 0.83152700 \\
\hline $\mathrm{H}$ & 2.09463300 & -1.57688100 & -0.70865100 \\
\hline $\mathrm{O}$ & 0.85817900 & 0.09324200 & 1.11075200 \\
\hline $\mathrm{H}$ & 3.65921000 & -0.73546600 & -0.60783100 \\
\hline $\mathrm{C}$ & 1.66771100 & 1.17510300 & -0.92577000 \\
\hline & 2.58390100 & 1.44806300 & -1.47199100 \\
\hline
\end{tabular}




$\begin{array}{lrrr}\mathrm{H} & 1.01869400 & 0.61303700 & -1.61094100 \\ \mathrm{H} & 1.14405600 & 2.10005900 & -0.65045900 \\ \mathrm{C} & -2.49263500 & 1.09852400 & 0.46844200 \\ \mathrm{H} & -2.76979800 & 0.65084700 & 1.43107400 \\ \mathrm{H} & -1.84123800 & 1.96134900 & 0.65914100 \\ \mathrm{H} & -3.40799300 & 1.45943600 & -0.02039200\end{array}$

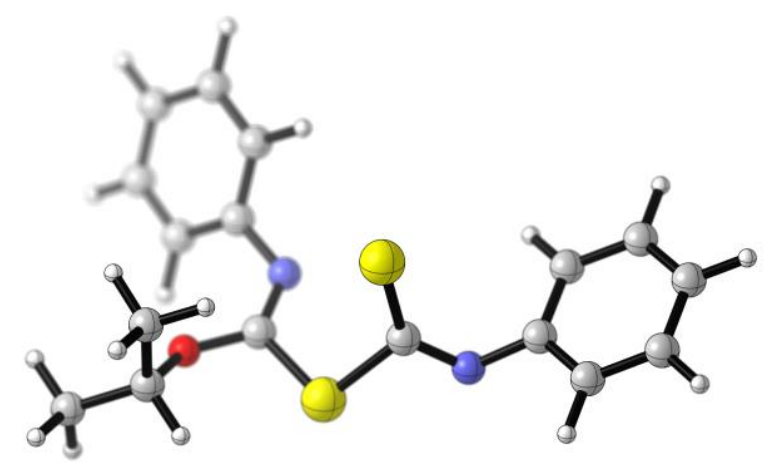

IN3

$\begin{array}{llrr}\text { C } & 2.55767200 & 2.65662200 & 0.26992700 \\ \text { H } & 1.78714500 & 3.33054500 & -0.11479600 \\ \text { C } & 3.93479200 & 3.22543300 & -0.02196600 \\ \text { H } & 4.71968300 & 2.54503300 & 0.32873100 \\ \text { H } & 4.06825400 & 3.39428300 & -1.09633000 \\ \text { H } & 4.05052300 & 4.18435300 & 0.49567100 \\ \text { C } & 2.31562900 & 2.36118500 & 1.74149400 \\ \text { H } & 2.37217400 & 3.29211100 & 2.31827300 \\ \text { H } & 1.32512300 & 1.91886900 & 1.89639000 \\ \text { H } & 3.07421800 & 1.66712600 & 2.12291400\end{array}$




\begin{tabular}{|c|c|c|c|}
\hline $\mathrm{O}$ & 2.48737300 & 1.40397400 & -0.49397200 \\
\hline $\mathrm{C}$ & 1.33354000 & 0.71162500 & -0.60820800 \\
\hline $\mathrm{N}$ & 1.28015000 & -0.56244500 & -0.61709200 \\
\hline$S$ & -0.13927600 & 1.67865400 & -0.91703100 \\
\hline $\mathrm{C}$ & 2.39607500 & -1.38137300 & -0.35523700 \\
\hline $\mathrm{C}$ & 2.21175400 & -2.45922100 & 0.52955900 \\
\hline $\mathrm{C}$ & 3.64016600 & -1.23343300 & -0.99621400 \\
\hline $\mathrm{C}$ & 3.25650900 & -3.34588900 & 0.79634900 \\
\hline $\mathrm{H}$ & 1.24342800 & -2.58372900 & 1.00666700 \\
\hline $\mathrm{C}$ & 4.67498600 & -2.13658500 & -0.74000500 \\
\hline $\mathrm{H}$ & 3.78908800 & -0.41858900 & -1.69625900 \\
\hline $\mathrm{C}$ & 4.49466300 & -3.19120800 & 0.16185600 \\
\hline $\mathrm{H}$ & 3.09942000 & -4.16478700 & 1.49432400 \\
\hline $\mathrm{H}$ & 5.62908100 & -2.01108300 & -1.24671800 \\
\hline $\mathrm{H}$ & 5.30524800 & -3.88718800 & 0.36181000 \\
\hline $\mathrm{C}$ & -1.49035800 & 0.70527100 & -0.08565500 \\
\hline $\mathrm{N}$ & -2.49323000 & 0.59238300 & -0.89572200 \\
\hline $\mathrm{C}$ & -3.69789200 & -0.00457700 & -0.47887100 \\
\hline $\mathrm{C}$ & -4.84681100 & 0.78768400 & -0.31664800 \\
\hline $\mathrm{C}$ & -3.80478800 & -1.39850800 & -0.32439900 \\
\hline $\mathrm{C}$ & -6.07198900 & 0.19969400 & 0.01231700 \\
\hline $\mathrm{H}$ & -4.76794100 & 1.86410200 & -0.44794500 \\
\hline
\end{tabular}




$\begin{array}{llll}\mathrm{C} & -5.03312600 & -1.98116400 & -0.00645600 \\ \mathrm{H} & -2.91954700 & -2.01385000 & -0.45793600 \\ \mathrm{C} & -6.17379200 & -1.18700300 & 0.16792100 \\ \mathrm{H} & -6.94988100 & 0.82871900 & 0.14145200 \\ \mathrm{H} & -5.09932500 & -3.06084600 & 0.10805300 \\ \mathrm{H} & -7.12836100 & -1.64380000 & 0.41637100 \\ \mathrm{~S} & -1.30996900 & 0.28047400 & 1.56929300\end{array}$

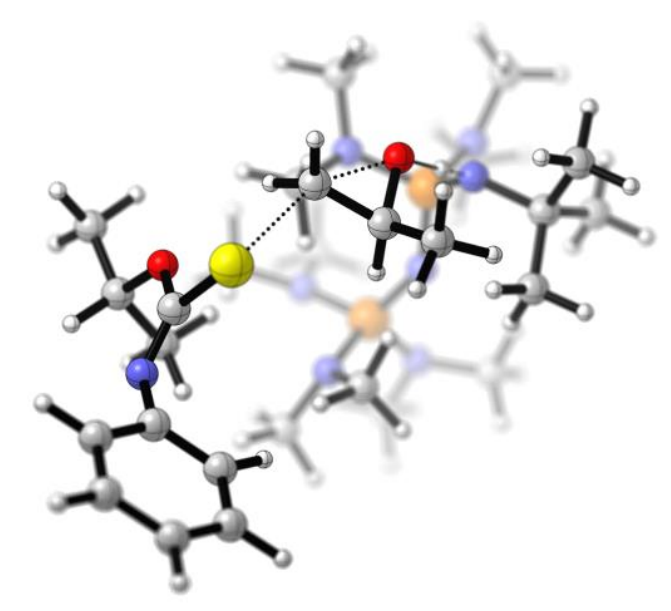

TS3

imaginary frequency $=443.06 i \mathrm{~cm}^{-1}$

$\begin{array}{llll}\mathrm{P} & -2.91853200 & 0.92249400 & 0.44749300 \\ \mathrm{~N} & -2.21125100 & 2.34043400 & -0.03506400 \\ \mathrm{~N} & -4.52259900 & 1.27794200 & 0.70671000 \\ \mathrm{~N} & -2.79009800 & -0.25483200 & -0.61382400 \\ \mathrm{~N} & -2.19923600 & 0.47794200 & 1.90311100\end{array}$




\begin{tabular}{|c|c|c|c|}
\hline $\mathrm{P}$ & -2.64021600 & -1.83174200 & -0.68103600 \\
\hline $\mathrm{N}$ & -1.04464400 & -2.18229900 & -1.06776700 \\
\hline $\mathrm{N}$ & -2.92117000 & -2.80740300 & 0.64157400 \\
\hline $\mathrm{N}$ & -3.78987200 & -2.36351900 & -1.78111200 \\
\hline $\mathrm{C}$ & -2.36077100 & 3.00625400 & -1.36483800 \\
\hline $\mathrm{C}$ & -1.40693700 & 2.36936500 & -2.38975200 \\
\hline $\mathrm{H}$ & -1.69346300 & 1.33256200 & -2.58485200 \\
\hline $\mathrm{H}$ & -1.44023600 & 2.92272500 & -3.33655100 \\
\hline $\mathrm{H}$ & -0.37617400 & 2.38022100 & -2.02414400 \\
\hline $\mathrm{C}$ & -1.99524200 & 4.48231200 & -1.14948000 \\
\hline $\mathrm{H}$ & -2.02719200 & 5.02527300 & -2.10154700 \\
\hline $\mathrm{H}$ & -2.70082400 & 4.95539700 & -0.45609600 \\
\hline $\mathrm{H}$ & -0.98819100 & 4.57159300 & -0.72898600 \\
\hline $\mathrm{C}$ & -3.79758800 & 2.90781200 & -1.89180300 \\
\hline $\mathrm{H}$ & -4.51196800 & 3.37073900 & -1.20613600 \\
\hline $\mathrm{H}$ & -3.85512600 & 3.43537700 & -2.85081500 \\
\hline $\mathrm{H}$ & -4.09923700 & 1.86986000 & -2.06226000 \\
\hline $\mathrm{C}$ & -4.97189900 & 2.52504300 & 1.32166300 \\
\hline $\mathrm{H}$ & -4.14098100 & 3.22334800 & 1.42022600 \\
\hline $\mathrm{H}$ & -5.74603000 & 2.98619100 & 0.69461600 \\
\hline $\mathrm{H}$ & -5.40215300 & 2.33958500 & 2.31555200 \\
\hline - & -5.57309300 & 0.27527300 & 0.57328000 \\
\hline
\end{tabular}




\begin{tabular}{|c|c|c|c|}
\hline $\mathrm{H}$ & -6.44798700 & 0.73905300 & 0.10015100 \\
\hline $\mathrm{H}$ & -5.23903900 & -0.54624200 & -0.05854700 \\
\hline $\mathrm{H}$ & -5.87930600 & -0.12505900 & 1.55030700 \\
\hline $\mathrm{C}$ & -2.60702400 & 1.13775100 & 3.14619800 \\
\hline $\mathrm{H}$ & -2.17729800 & 2.14549200 & 3.25076000 \\
\hline $\mathrm{H}$ & -3.69394300 & 1.20307100 & 3.20522600 \\
\hline $\mathrm{H}$ & -2.25786700 & 0.52651200 & 3.98572200 \\
\hline $\mathrm{C}$ & -0.76545800 & 0.15739800 & 1.88096400 \\
\hline $\mathrm{H}$ & -0.50871300 & -0.36235500 & 0.95762400 \\
\hline $\mathrm{H}$ & -0.15387700 & 1.06322300 & 1.95762300 \\
\hline $\mathrm{H}$ & -0.54226000 & -0.50606500 & 2.72147100 \\
\hline $\mathrm{C}$ & -4.28233700 & -3.03693800 & 1.12934000 \\
\hline $\mathrm{H}$ & -4.35859700 & -4.06662500 & 1.49927300 \\
\hline $\mathrm{H}$ & -4.52364900 & -2.35152500 & 1.95344800 \\
\hline $\mathrm{H}$ & -5.00946600 & -2.89740700 & 0.32979900 \\
\hline $\mathrm{C}$ & -1.91266500 & -3.02112900 & 1.68106000 \\
\hline $\mathrm{H}$ & -2.11018700 & -2.38118700 & 2.55061100 \\
\hline $\mathrm{H}$ & -1.94908200 & -4.06972300 & 2.00181800 \\
\hline $\mathrm{H}$ & -0.91658700 & -2.80209100 & 1.30222300 \\
\hline $\mathrm{C}$ & -3.91121000 & -3.78550500 & -2.10956300 \\
\hline $\mathrm{H}$ & -3.58471600 & -4.40445600 & -1.27290300 \\
\hline $\mathrm{H}$ & -4.96388700 & -4.01207100 & -2.31839300 \\
\hline
\end{tabular}




\begin{tabular}{|c|c|c|c|}
\hline $\mathrm{H}$ & -3.31823800 & -4.04776900 & -2.99732300 \\
\hline $\mathrm{C}$ & -4.24102300 & -1.48578500 & -2.86158200 \\
\hline $\mathrm{H}$ & -3.61422100 & -1.59281500 & -3.75998300 \\
\hline $\mathrm{H}$ & -5.27139200 & -1.75357500 & -3.12501600 \\
\hline $\mathrm{H}$ & -4.21833700 & -0.44712400 & -2.53444700 \\
\hline $\mathrm{C}$ & -0.65836700 & -3.56323300 & -1.37125100 \\
\hline $\mathrm{H}$ & -1.24732300 & -4.26747500 & -0.78172800 \\
\hline $\mathrm{H}$ & -0.79029000 & -3.79629000 & -2.43771500 \\
\hline $\mathrm{H}$ & 0.39843400 & -3.69744400 & -1.11579800 \\
\hline $\mathrm{C}$ & -0.23634100 & -1.19368100 & -1.78351400 \\
\hline $\mathrm{H}$ & -0.41811500 & -1.22092400 & -2.86879400 \\
\hline $\mathrm{H}$ & -0.45372200 & -0.19370700 & -1.41433400 \\
\hline $\mathrm{H}$ & 0.82073000 & -1.41514200 & -1.60353300 \\
\hline $\mathrm{H}$ & -1.27216400 & 2.50967500 & 0.36776800 \\
\hline $\mathrm{O}$ & 0.44483400 & 3.09551600 & 0.84418200 \\
\hline $\mathrm{C}$ & 1.50674400 & 2.68908900 & 0.01697900 \\
\hline $\mathrm{C}$ & 2.15796500 & 2.48891800 & 1.31380300 \\
\hline $\mathrm{H}$ & 1.30811100 & 1.75018300 & -0.52466000 \\
\hline $\mathrm{H}$ & 1.95206700 & 1.59560700 & 1.88350000 \\
\hline $\mathrm{H}$ & 2.54341200 & 3.35604200 & 1.83305400 \\
\hline $\mathrm{C}$ & 2.06748300 & 3.74813300 & -0.91598700 \\
\hline $\mathrm{H}$ & 2.97999600 & 3.38780800 & -1.40697400 \\
\hline
\end{tabular}




\begin{tabular}{|c|c|c|c|}
\hline $\mathrm{H}$ & 1.33457600 & 3.99984900 & -1.69132100 \\
\hline $\mathrm{H}$ & 2.30662700 & 4.66114000 & -0.35649400 \\
\hline$S$ & 4.51884000 & 1.65279600 & 0.93773900 \\
\hline $\mathrm{C}$ & 4.32223500 & -0.08542000 & 1.08500800 \\
\hline $\mathrm{N}$ & 5.01921100 & -1.01442200 & 0.52222500 \\
\hline $\mathrm{O}$ & 3.32000300 & -0.43769000 & 1.93588000 \\
\hline $\mathrm{C}$ & 3.03475100 & -1.85097400 & 2.15638100 \\
\hline $\mathrm{H}$ & 3.99106400 & -2.38006800 & 2.19367400 \\
\hline $\mathrm{C}$ & 2.34141000 & -1.92363200 & 3.50820300 \\
\hline $\mathrm{H}$ & 1.40531100 & -1.35389800 & 3.49895300 \\
\hline $\mathrm{H}$ & 2.10689700 & -2.96720400 & 3.74917300 \\
\hline $\mathrm{H}$ & 2.98566400 & -1.52295400 & 4.29900400 \\
\hline $\mathrm{C}$ & 2.18067800 & -2.39842600 & 1.01930500 \\
\hline $\mathrm{H}$ & 1.95760800 & -3.45703000 & 1.19912600 \\
\hline $\mathrm{H}$ & 1.23401400 & -1.85365700 & 0.95323100 \\
\hline $\mathrm{H}$ & 2.70336100 & -2.31575100 & 0.06235400 \\
\hline $\mathrm{C}$ & 6.02493500 & -0.72646100 & -0.40966500 \\
\hline $\mathrm{C}$ & 7.37895900 & -0.85507300 & -0.05247900 \\
\hline $\mathrm{C}$ & 5.70725200 & -0.41435200 & -1.74546400 \\
\hline $\mathrm{C}$ & 8.38726200 & -0.65481000 & -0.99990700 \\
\hline $\mathrm{H}$ & 7.62960400 & -1.10841200 & 0.97480300 \\
\hline $\mathrm{C}$ & 6.71747000 & -0.21951200 & -2.68925600 \\
\hline
\end{tabular}




$\begin{array}{llll}\mathrm{H} & 4.66204100 & -0.32414300 & -2.02978400 \\ \mathrm{C} & 8.06467500 & -0.33613400 & -2.32372500 \\ \mathrm{H} & 9.42878200 & -0.75187900 & -0.70151700 \\ \mathrm{H} & 6.45148400 & 0.02394000 & -3.71559200 \\ \mathrm{H} & 8.84954100 & -0.18562200 & -3.06052100\end{array}$

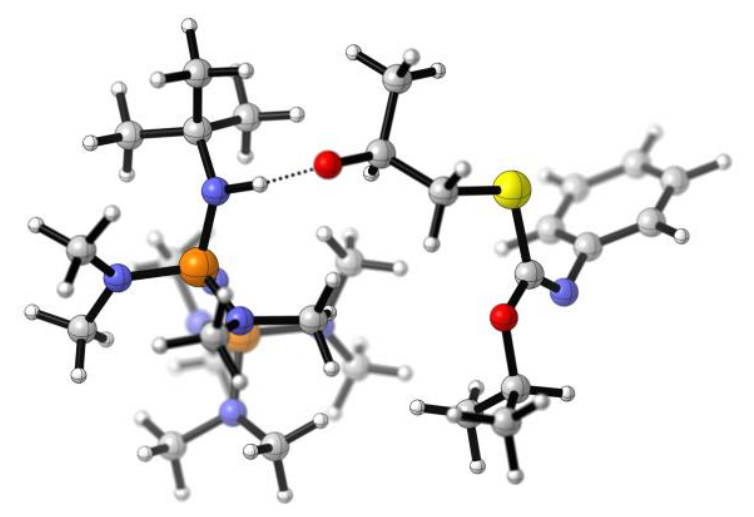

IN4

$\begin{array}{llrr}\mathrm{P} & -2.79078300 & 0.78843200 & 0.36982800 \\ \mathrm{~N} & -2.27460700 & 2.23064500 & -0.22628200 \\ \mathrm{~N} & -4.44501800 & 0.91540200 & 0.57180400 \\ \mathrm{~N} & -2.48859700 & -0.45516600 & -0.58362700 \\ \mathrm{~N} & -2.09316900 & 0.54663600 & 1.88433200 \\ \mathrm{P} & -2.06147600 & -1.97575100 & -0.57860900 \\ \mathrm{~N} & -0.38535000 & -2.07329600 & -0.65988500 \\ \mathrm{~N} & -2.41404400 & -2.98980500 & 0.70023900 \\ \mathrm{~N} & -2.88148200 & -2.69187500 & -1.85808700\end{array}$




\begin{tabular}{|c|c|c|c|}
\hline $\mathrm{C}$ & -2.49823500 & 2.73221600 & -1.61542500 \\
\hline $\mathrm{C}$ & -1.43904200 & 2.15257100 & -2.57055800 \\
\hline $\mathrm{H}$ & -1.55221900 & 1.06751200 & -2.64838600 \\
\hline $\mathrm{H}$ & -1.55007700 & 2.58530200 & -3.57310500 \\
\hline $\mathrm{H}$ & -0.42903000 & 2.36820400 & -2.21334200 \\
\hline $\mathrm{C}$ & -2.36835700 & 4.26163700 & -1.54630800 \\
\hline $\mathrm{H}$ & -2.42868500 & 4.69683900 & -2.55140800 \\
\hline $\mathrm{H}$ & -3.17567000 & 4.68630700 & -0.93676700 \\
\hline $\mathrm{H}$ & -1.41351600 & 4.54023600 & -1.09071800 \\
\hline $\mathrm{C}$ & -3.89028300 & 2.37303600 & -2.15430400 \\
\hline $\mathrm{H}$ & -4.68500300 & 2.78897100 & -1.52982300 \\
\hline $\mathrm{H}$ & -3.99543600 & 2.79334800 & -3.16158300 \\
\hline $\mathrm{H}$ & -4.03529300 & 1.29124300 & -2.22651700 \\
\hline $\mathrm{C}$ & -5.09507600 & 2.14245700 & 1.02380400 \\
\hline $\mathrm{H}$ & -4.39280800 & 2.97575300 & 0.99750400 \\
\hline $\mathrm{H}$ & -5.94226300 & 2.37460100 & 0.36492500 \\
\hline $\mathrm{H}$ & -5.48094300 & 2.03476000 & 2.04764500 \\
\hline $\mathrm{C}$ & -5.29162000 & -0.26691500 & 0.66320800 \\
\hline $\mathrm{H}$ & -6.26677500 & -0.04278600 & 0.21266200 \\
\hline $\mathrm{H}$ & -4.84579800 & -1.09519700 & 0.11427000 \\
\hline $\mathrm{H}$ & -5.45689500 & -0.57621900 & 1.70653500 \\
\hline $\mathrm{C}$ & -2.64566800 & 1.24679700 & 3.04639200 \\
\hline
\end{tabular}




\begin{tabular}{|c|c|c|c|}
\hline $\mathrm{H}$ & -2.36144000 & 2.30931300 & 3.07932000 \\
\hline $\mathrm{H}$ & -3.73303600 & 1.16699200 & 3.06051400 \\
\hline $\mathrm{H}$ & -2.25991400 & 0.76124700 & 3.94993300 \\
\hline $\mathrm{C}$ & -0.63180500 & 0.40799900 & 1.95921700 \\
\hline $\mathrm{H}$ & -0.26414800 & -0.18161000 & 1.11995000 \\
\hline $\mathrm{H}$ & -0.14871700 & 1.39131800 & 1.94523200 \\
\hline $\mathrm{H}$ & -0.38058800 & -0.12248300 & 2.88364600 \\
\hline $\mathrm{C}$ & -3.75004000 & -3.55710500 & 0.88779200 \\
\hline $\mathrm{H}$ & -3.65269400 & -4.59406100 & 1.23333900 \\
\hline $\mathrm{H}$ & -4.31393700 & -2.99212900 & 1.64240900 \\
\hline $\mathrm{H}$ & -4.30759900 & -3.54910400 & -0.04855000 \\
\hline $\mathrm{C}$ & -1.64965400 & -2.92755600 & 1.94722500 \\
\hline $\mathrm{H}$ & -2.15977400 & -2.29892500 & 2.68932200 \\
\hline $\mathrm{H}$ & -1.54840000 & -3.94126300 & 2.35436500 \\
\hline $\mathrm{H}$ & -0.65646200 & -2.52142500 & 1.76813500 \\
\hline $\mathrm{C}$ & -2.58700400 & -4.08086800 & -2.21753400 \\
\hline $\mathrm{H}$ & -2.31370600 & -4.66012400 & -1.33429400 \\
\hline $\mathrm{H}$ & -3.48483300 & -4.52972800 & -2.65892800 \\
\hline $\mathrm{H}$ & -1.77067200 & -4.14709700 & -2.95144700 \\
\hline $\mathrm{C}$ & -3.31280400 & -1.88615500 & -3.00062100 \\
\hline $\mathrm{H}$ & -2.51632400 & -1.78414500 & -3.75396200 \\
\hline $\mathrm{H}$ & -4.17200000 & -2.37899100 & -3.47112600 \\
\hline
\end{tabular}




\begin{tabular}{|c|c|c|c|}
\hline $\mathrm{H}$ & -3.61220000 & -0.89434100 & -2.66558100 \\
\hline $\mathrm{C}$ & 0.29400900 & -3.37071800 & -0.70245800 \\
\hline $\mathrm{H}$ & -0.28493800 & -4.12855600 & -0.17353100 \\
\hline $\mathrm{H}$ & 0.45727700 & -3.70697700 & -1.73635900 \\
\hline $\mathrm{H}$ & 1.27009200 & -3.27484100 & -0.21368600 \\
\hline $\mathrm{C}$ & 0.36911600 & -1.02040700 & -1.34113600 \\
\hline $\mathrm{H}$ & 0.47227200 & -1.22483600 & -2.41786900 \\
\hline $\mathrm{H}$ & -0.12052900 & -0.05787600 & -1.21003100 \\
\hline $\mathrm{H}$ & 1.37138600 & -0.96550500 & -0.90244300 \\
\hline $\mathrm{H}$ & -1.38345000 & 2.63989000 & 0.20897500 \\
\hline $\mathrm{O}$ & -0.00874200 & 3.38566000 & 0.74302500 \\
\hline $\mathrm{C}$ & 1.09786500 & 2.95612000 & 0.05898100 \\
\hline $\mathrm{C}$ & 2.23632300 & 2.62050300 & 1.05980000 \\
\hline $\mathrm{H}$ & 0.90628200 & 2.00795700 & -0.49954900 \\
\hline $\mathrm{H}$ & 1.87302300 & 1.94923500 & 1.83507200 \\
\hline $\mathrm{H}$ & 2.61078000 & 3.53430100 & 1.53473800 \\
\hline $\mathrm{C}$ & 1.60295700 & 3.98811700 & -0.97349700 \\
\hline $\mathrm{H}$ & 2.47269600 & 3.63120600 & -1.54559900 \\
\hline $\mathrm{H}$ & 0.80745100 & 4.22860700 & -1.68709900 \\
\hline $\mathrm{H}$ & 1.88591200 & 4.91646600 & -0.45703600 \\
\hline $\mathrm{S}$ & 3.68158100 & 1.78173200 & 0.24839300 \\
\hline $\mathrm{C}$ & 3.86528500 & 0.22780000 & 1.11460800 \\
\hline
\end{tabular}




\begin{tabular}{|c|c|c|c|}
\hline $\mathrm{N}$ & 4.60286500 & -0.72921400 & 0.69491300 \\
\hline $\mathrm{O}$ & 3.19563100 & 0.16547000 & 2.26968000 \\
\hline $\mathrm{C}$ & 3.28291000 & -1.05799000 & 3.07814300 \\
\hline $\mathrm{H}$ & 4.32011000 & -1.40030000 & 3.02925000 \\
\hline $\mathrm{C}$ & 2.92615200 & -0.62943600 & 4.49088100 \\
\hline $\mathrm{H}$ & 1.90397200 & -0.23538700 & 4.53294900 \\
\hline $\mathrm{H}$ & 2.99099000 & -1.49353200 & 5.16194000 \\
\hline $\mathrm{H}$ & 3.61524600 & 0.14175600 & 4.85232800 \\
\hline $\mathrm{C}$ & 2.34581400 & -2.11496000 & 2.51433900 \\
\hline $\mathrm{H}$ & 2.41081200 & -3.02431600 & 3.12365000 \\
\hline $\mathrm{H}$ & 1.31165000 & -1.75821200 & 2.53534600 \\
\hline $\mathrm{H}$ & 2.61282400 & -2.37240400 & 1.48626300 \\
\hline $\mathrm{C}$ & 5.27177300 & -0.65064700 & -0.54349800 \\
\hline $\mathrm{C}$ & 6.61138200 & -0.23348600 & -0.60272700 \\
\hline $\mathrm{C}$ & 4.63290700 & -1.07601400 & -1.72095500 \\
\hline $\mathrm{C}$ & 7.29126900 & -0.22134500 & -1.82370700 \\
\hline $\mathrm{H}$ & 7.10749500 & 0.08360500 & 0.31098400 \\
\hline $\mathrm{C}$ & 5.31826900 & -1.06198800 & -2.93753700 \\
\hline $\mathrm{H}$ & 3.59943500 & -1.40785600 & -1.67138700 \\
\hline $\mathrm{C}$ & 6.64983900 & -0.63394200 & -2.99686100 \\
\hline $\mathrm{H}$ & 8.32625800 & 0.11050600 & -1.85640900 \\
\hline $\mathrm{H}$ & 4.80956300 & -1.38773000 & -3.84180300 \\
\hline
\end{tabular}




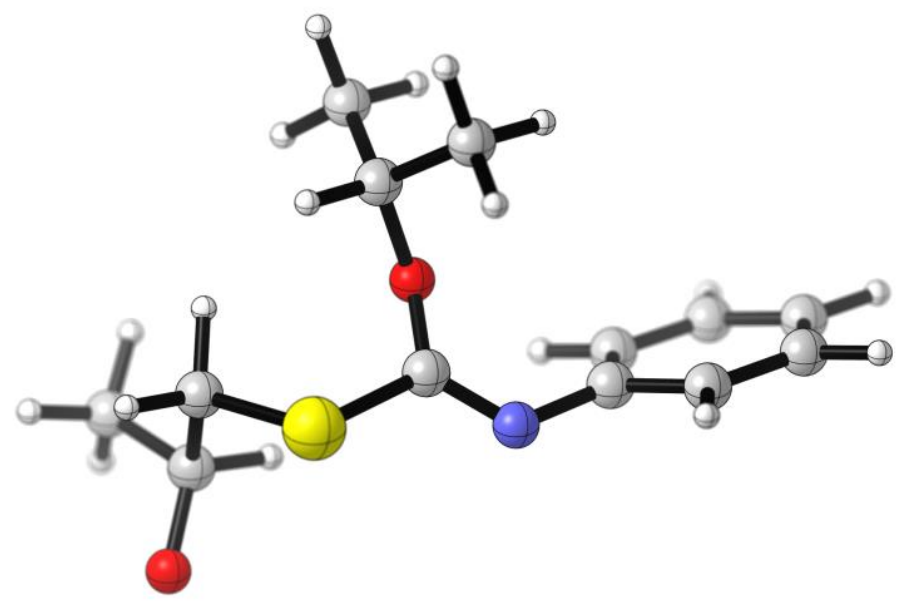

IN5

\begin{tabular}{|c|c|c|c|}
\hline $\mathrm{C}$ & -4.60483600 & -0.72646200 & 0.92084300 \\
\hline $\mathrm{C}$ & -4.45715700 & -0.82928800 & -0.46709400 \\
\hline $\mathrm{C}$ & -3.18463000 & -0.90110400 & -1.03759700 \\
\hline $\mathrm{C}$ & -2.03567800 & -0.84089600 & -0.22976400 \\
\hline $\mathrm{C}$ & -2.18773800 & -0.74680000 & 1.16566600 \\
\hline $\mathrm{C}$ & -3.46383600 & -0.69491800 & 1.73092300 \\
\hline $\mathrm{H}$ & -5.59541500 & -0.68029300 & 1.36575100 \\
\hline $\mathrm{H}$ & -5.33460600 & -0.86281800 & -1.10846300 \\
\hline $\mathrm{H}$ & -3.06489000 & -0.99656400 & -2.11374400 \\
\hline 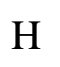 & -1.30745100 & -0.72182400 & 1.79901800 \\
\hline $\mathrm{H}$ & -3.56543100 & -0.62583100 & 2.81147700 \\
\hline 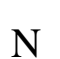 & -0.78160200 & -0.97368500 & -0.85990700 \\
\hline
\end{tabular}




\begin{tabular}{|c|c|c|c|}
\hline $\mathrm{C}$ & 0.18822200 & -0.16762600 & -0.63693600 \\
\hline $\mathrm{O}$ & 0.14192400 & 0.81991200 & 0.28800500 \\
\hline S & 1.66590700 & -0.36840000 & -1.61421400 \\
\hline $\mathrm{C}$ & 0.33506600 & 2.20777500 & -0.15253800 \\
\hline $\mathrm{H}$ & 1.23904600 & 2.24220700 & -0.76750000 \\
\hline $\mathrm{C}$ & 0.53142300 & 3.01556300 & 1.11666400 \\
\hline $\mathrm{H}$ & 0.71123400 & 4.06564700 & 0.85995800 \\
\hline $\mathrm{H}$ & -0.36053800 & 2.96198400 & 1.75198000 \\
\hline $\mathrm{H}$ & 1.39154200 & 2.64556600 & 1.68508300 \\
\hline $\mathrm{C}$ & -0.86513800 & 2.64745400 & -0.97830300 \\
\hline $\mathrm{H}$ & -0.71417700 & 3.67740000 & -1.32301700 \\
\hline $\mathrm{H}$ & -0.99298600 & 2.01142000 & -1.86164800 \\
\hline $\mathrm{H}$ & -1.78348100 & 2.60930200 & -0.38162700 \\
\hline $\mathrm{C}$ & 2.99262800 & 0.03962100 & -0.40154500 \\
\hline $\mathrm{H}$ & 3.88236700 & 0.18583700 & -1.02652800 \\
\hline $\mathrm{H}$ & 2.74618800 & 0.99332800 & 0.07494000 \\
\hline $\mathrm{C}$ & 3.28304400 & -1.09829500 & 0.62465300 \\
\hline $\mathrm{H}$ & 2.29607800 & -1.27114500 & 1.14403200 \\
\hline $\mathrm{C}$ & 4.20740600 & -0.46834900 & 1.70705700 \\
\hline $\mathrm{H}$ & 4.43520800 & -1.22621700 & 2.46792300 \\
\hline $\mathrm{H}$ & 5.15920800 & -0.15125300 & 1.25450400 \\
\hline $\mathrm{H}$ & 3.75324300 & 0.40053300 & 2.20993000 \\
\hline
\end{tabular}




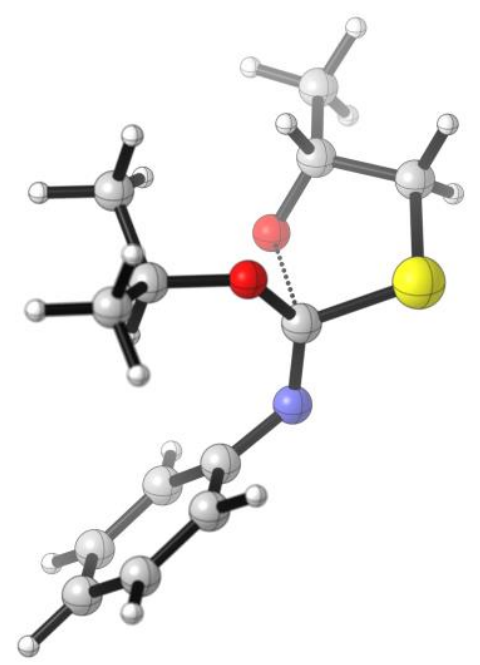

TS4

imaginary frequency $=119.64 i \mathrm{~cm}^{-1}$
C
$-3.01117500$
0.15021500
0.61156700
C
$\begin{array}{lll}-3.37571400 & -1.00198400 & -0.36080200\end{array}$
C
$-0.54548700$
$-0.58133900$
$-0.48792400$
$\mathrm{H}$
$-2.98374900$
1.07716800
$-0.01218900$
$\mathrm{H}$
$-4.16439800$
$-0.71256200$
$-1.06571700$
$\mathrm{H}$
$-3.71051300$
$-1.87907000$
0.20583300
C
$-4.17453600$
0.32855600
1.60715400
$\mathrm{H}$
$-3.97617800$
1.18726000
2.26157500
$\mathrm{H}$
$-5.13320500$
0.50186300
1.09514300
$\mathrm{H}$
$\begin{array}{lll}-4.27220200 & -0.56499400 & 2.23917800\end{array}$
$\mathrm{O}$
$\begin{array}{lll}-1.81585400 & -0.09125400 & 1.21967000\end{array}$
S
$\begin{array}{lll}-1.88864600 & -1.51031900 & -1.31617600\end{array}$ 


\begin{tabular}{|c|c|c|c|}
\hline $\mathrm{N}$ & 0.43234600 & -1.30115900 & -0.04810300 \\
\hline $\mathrm{C}$ & 1.74703400 & -0.89075500 & 0.17698500 \\
\hline $\mathrm{C}$ & 2.24833200 & -0.79761300 & 1.49314200 \\
\hline $\mathrm{C}$ & 2.64789500 & -0.69901500 & -0.89115500 \\
\hline $\mathrm{C}$ & 3.58833900 & -0.48625900 & 1.72815700 \\
\hline $\mathrm{H}$ & 1.56501900 & -0.95995100 & 2.32307000 \\
\hline $\mathrm{C}$ & 3.98957000 & -0.39420200 & -0.64986400 \\
\hline $\mathrm{H}$ & 2.28109000 & -0.79280300 & -1.90992800 \\
\hline $\mathrm{C}$ & 4.47072300 & -0.27907000 & 0.65953200 \\
\hline $\mathrm{H}$ & 3.94728000 & -0.40846200 & 2.75226900 \\
\hline $\mathrm{H}$ & 4.66300000 & -0.24653700 & -1.49166000 \\
\hline $\mathrm{H}$ & 5.51526600 & -0.04197800 & 0.84462100 \\
\hline $\mathrm{O}$ & -0.48523800 & 0.69296900 & -0.98497800 \\
\hline $\mathrm{C}$ & 0.27123000 & 1.74523100 & -0.31557100 \\
\hline $\mathrm{H}$ & 0.90230800 & 1.29351200 & 0.44956600 \\
\hline $\mathrm{C}$ & 1.13127600 & 2.41783300 & -1.37709700 \\
\hline $\mathrm{H}$ & 1.72051700 & 3.22509900 & -0.92520400 \\
\hline $\mathrm{H}$ & 1.82013800 & 1.70522500 & -1.83943300 \\
\hline $\mathrm{H}$ & 0.49831700 & 2.85262300 & -2.16097100 \\
\hline $\mathrm{C}$ & -0.70020900 & 2.71484300 & 0.34429500 \\
\hline $\mathrm{H}$ & -1.35279600 & 3.18111300 & -0.40431400 \\
\hline $\mathrm{H}$ & -1.30598300 & 2.17357800 & 1.07503500 \\
\hline
\end{tabular}




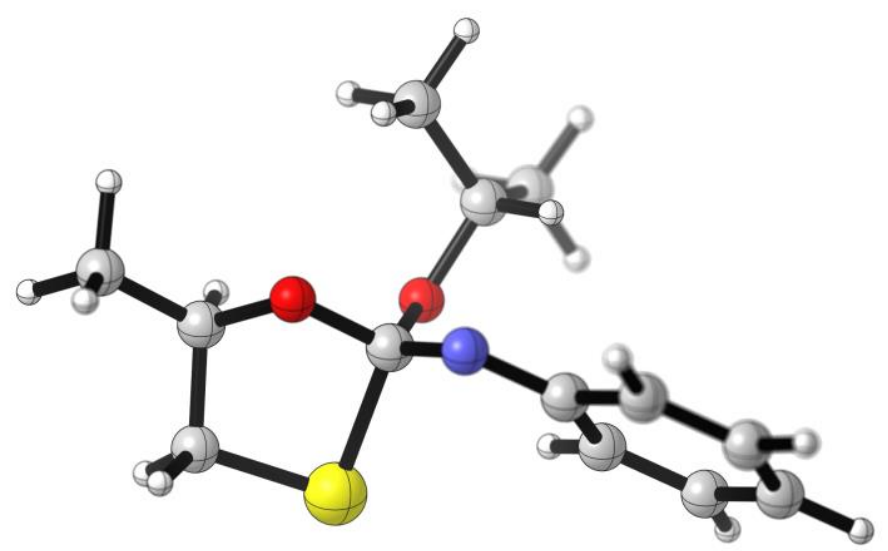

IN6

\begin{tabular}{|c|c|c|c|}
\hline $\mathrm{C}$ & 2.98494700 & -0.51996800 & -0.09406100 \\
\hline $\mathrm{C}$ & 2.67679800 & -1.82497900 & 0.64560600 \\
\hline $\mathrm{C}$ & 0.64069500 & -0.20048100 & -0.20062600 \\
\hline $\mathrm{H}$ & 3.09702000 & 0.28989400 & 0.63894200 \\
\hline $\mathrm{H}$ & 3.33308700 & -1.94754600 & 1.51304900 \\
\hline $\mathrm{H}$ & 2.80975200 & -2.68233400 & -0.02408600 \\
\hline $\mathrm{C}$ & 4.21244000 & -0.59360300 & -0.98500400 \\
\hline $\mathrm{H}$ & 4.38755500 & 0.36582000 & -1.48544100 \\
\hline $\mathrm{H}$ & 5.09690400 & -0.83345900 & -0.38278100 \\
\hline $\mathrm{H}$ & 4.09059800 & -1.37016100 & -1.74957900 \\
\hline O & 1.85009000 & -0.24746600 & -0.91961400 \\
\hline S & 0.92950700 & -1.68001500 & 1.17315300 \\
\hline & -0.40091800 & -0.38335400 & -1.06271000 \\
\hline
\end{tabular}




\begin{tabular}{|c|c|c|c|}
\hline $\mathrm{C}$ & -1.68203600 & -0.41595200 & -0.60088100 \\
\hline $\mathrm{C}$ & -2.72873500 & -0.59447900 & -1.55862700 \\
\hline $\mathrm{C}$ & -2.10209700 & -0.30928500 & 0.76210400 \\
\hline $\mathrm{C}$ & -4.06725100 & -0.66890500 & -1.19020600 \\
\hline $\mathrm{H}$ & -2.44558200 & -0.67684600 & -2.60662000 \\
\hline $\mathrm{C}$ & -3.45040800 & -0.39502800 & 1.11865300 \\
\hline $\mathrm{H}$ & -1.36074300 & -0.13758000 & 1.53373600 \\
\hline $\mathrm{C}$ & -4.45381100 & -0.57415500 & 0.15853900 \\
\hline $\mathrm{H}$ & -4.82335900 & -0.80535400 & -1.96212100 \\
\hline $\mathrm{H}$ & -3.71966500 & -0.31055500 & 2.17097800 \\
\hline $\mathrm{H}$ & -5.50057200 & -0.63373400 & 0.44583900 \\
\hline $\mathrm{O}$ & 0.62155200 & 0.93772400 & 0.66675400 \\
\hline $\mathrm{C}$ & 0.18319300 & 2.19180700 & 0.09680100 \\
\hline $\mathrm{H}$ & -0.74621700 & 2.01644500 & -0.45590900 \\
\hline $\mathrm{C}$ & -0.10241100 & 3.10031600 & 1.28615900 \\
\hline $\mathrm{H}$ & -0.48059400 & 4.07041800 & 0.94129900 \\
\hline $\mathrm{H}$ & -0.85347100 & 2.65107200 & 1.94556200 \\
\hline $\mathrm{H}$ & 0.81133500 & 3.27486900 & 1.86879600 \\
\hline $\mathrm{C}$ & 1.22400900 & 2.79190800 & -0.84744500 \\
\hline $\mathrm{H}$ & 2.17398300 & 2.95282600 & -0.32182700 \\
\hline $\mathrm{H}$ & 1.40927800 & 2.13412900 & -1.70065600 \\
\hline $\mathrm{H}$ & 0.86986700 & 3.76057700 & -1.22385500 \\
\hline
\end{tabular}




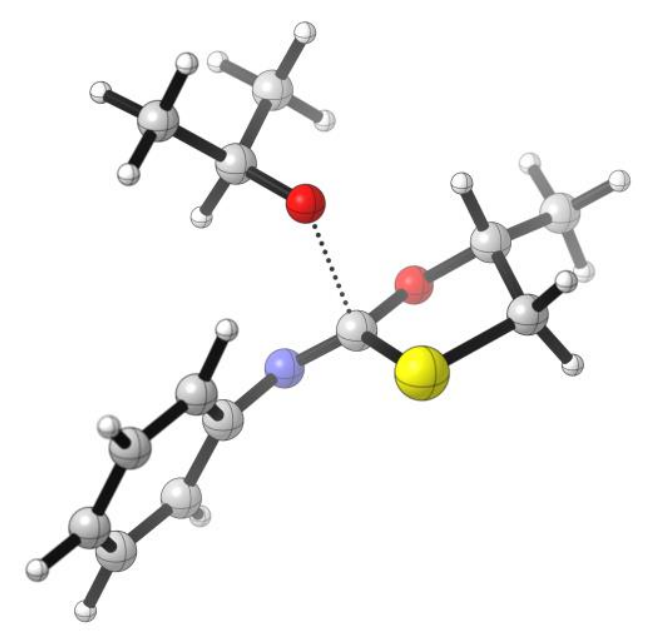

\section{TS5}

imaginary frequency $=143.88 i \mathrm{~cm}^{-1}$

\begin{tabular}{|c|c|c|c|}
\hline $\mathrm{C}$ & -2.84154000 & -0.83421700 & -0.01758500 \\
\hline $\mathrm{C}$ & -2.36314100 & -1.92924400 & -0.97166500 \\
\hline $\mathrm{C}$ & -0.55976200 & -0.62031400 & 0.37661300 \\
\hline $\mathrm{H}$ & -2.91771600 & 0.11358700 & -0.55794900 \\
\hline $\mathrm{H}$ & -2.86538900 & -1.85779000 & -1.93978900 \\
\hline $\mathrm{H}$ & -2.52484000 & -2.92701300 & -0.55073100 \\
\hline $\mathrm{C}$ & -4.11979500 & -1.17675800 & 0.72003000 \\
\hline $\mathrm{H}$ & -4.00260200 & -2.09711000 & 1.30447500 \\
\hline $\mathrm{H}$ & -4.40871800 & -0.36392100 & 1.39569700 \\
\hline $\mathrm{H}$ & -4.93068300 & -1.32431100 & -0.00293800 \\
\hline $\mathrm{O}$ & -1.78530100 & -0.65642700 & 0.95544100 \\
\hline $\mathrm{S}$ & -0.56589200 & -1.60975300 & -1.16832200 \\
\hline $\mathrm{N}$ & 0.45991300 & -0.41641000 & 1.14126400 \\
\hline
\end{tabular}




\begin{tabular}{|c|c|c|c|}
\hline $\mathrm{C}$ & 1.75486300 & -0.41462100 & 0.62684600 \\
\hline $\mathrm{C}$ & 2.80163000 & -0.94186500 & 1.41229800 \\
\hline $\mathrm{C}$ & 2.07741700 & 0.15998200 & -0.62309200 \\
\hline $\mathrm{C}$ & 4.11938800 & -0.92367500 & 0.95180100 \\
\hline $\mathrm{H}$ & 2.56255300 & -1.36841600 & 2.38394400 \\
\hline $\mathrm{C}$ & 3.39912300 & 0.17580500 & -1.07387300 \\
\hline $\mathrm{H}$ & 1.26857100 & 0.61813500 & -1.18831900 \\
\hline $\mathrm{C}$ & 4.42959400 & -0.36880400 & -0.29694400 \\
\hline $\mathrm{H}$ & 4.90870400 & -1.34408200 & 1.57145400 \\
\hline $\mathrm{H}$ & 3.62829000 & 0.62735300 & -2.03742400 \\
\hline $\mathrm{H}$ & 5.45694900 & -0.35278300 & -0.65231400 \\
\hline $\mathrm{O}$ & -0.87908500 & 1.30340000 & -0.75535200 \\
\hline $\mathrm{C}$ & -0.63775500 & 2.35992000 & 0.08645400 \\
\hline $\mathrm{H}$ & 0.07397000 & 2.05886200 & 0.89668900 \\
\hline $\mathrm{C}$ & 0.02916600 & 3.54276800 & -0.65169300 \\
\hline $\mathrm{H}$ & 0.27308600 & 4.37508800 & 0.02701100 \\
\hline $\mathrm{H}$ & 0.95757700 & 3.21303600 & -1.13565000 \\
\hline $\mathrm{H}$ & -0.64204400 & 3.92489800 & -1.43529700 \\
\hline $\mathrm{C}$ & -1.91549000 & 2.85281700 & 0.80701300 \\
\hline $\mathrm{H}$ & -1.70939200 & 3.67004600 & 1.51641800 \\
\hline $\mathrm{H}$ & -2.64865800 & 3.21487900 & 0.07037000 \\
\hline $\mathrm{H}$ & -2.37187600 & 2.02391900 & 1.36071300 \\
\hline
\end{tabular}




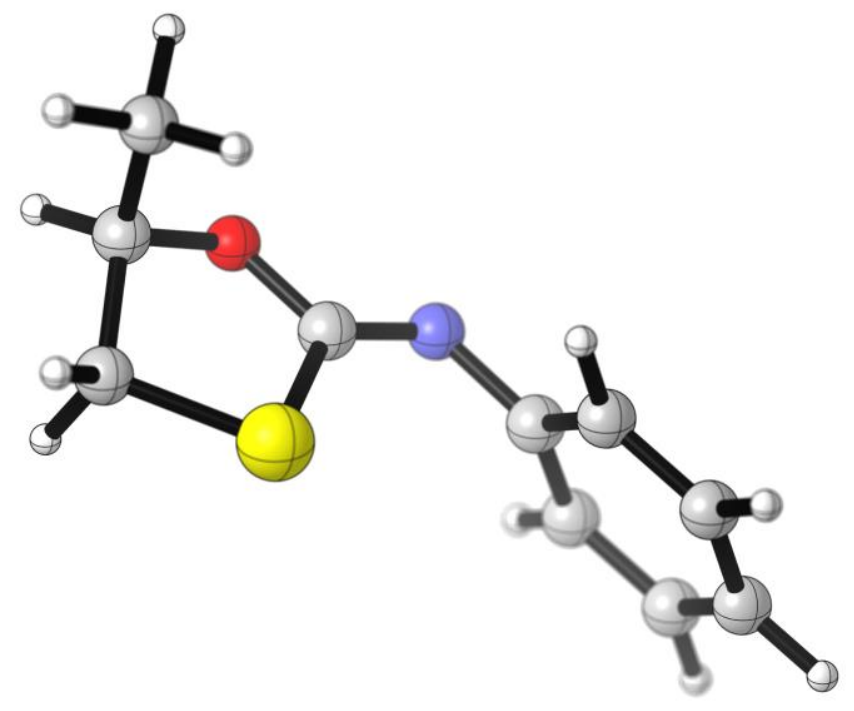

IN7

\begin{tabular}{|c|c|c|c|}
\hline $\mathrm{C}$ & 0.60658579 & 2.00173310 & 0.00000000 \\
\hline $\mathrm{C}$ & 1.04158679 & 1.18898810 & -1.22269200 \\
\hline $\mathrm{C}$ & 2.94819179 & 2.24604010 & 0.14856400 \\
\hline $\mathrm{H}$ & -0.16280221 & 2.72308210 & -0.28280000 \\
\hline $\mathrm{H}$ & 0.95152879 & 1.76520510 & -2.14655200 \\
\hline $\mathrm{H}$ & 0.47475879 & 0.26018910 & -1.31303400 \\
\hline $\mathrm{C}$ & 0.15121879 & 1.16698410 & 1.18543300 \\
\hline $\mathrm{H}$ & -0.05776521 & 1.81274110 & 2.04455800 \\
\hline $\mathrm{H}$ & -0.76818021 & 0.63197910 & 0.92187400 \\
\hline $\mathrm{H}$ & 0.91213079 & 0.43283910 & 1.47323900 \\
\hline $\mathrm{O}$ & 1.75353679 & 2.81986610 & 0.38676400 \\
\hline$S$ & 2.81086879 & 0.80441910 & -0.91607900 \\
\hline
\end{tabular}




\begin{tabular}{llrr} 
N & 4.00747079 & 2.75639010 & 0.63124500 \\
$\mathrm{C}$ & 5.26358279 & 2.16679110 & 0.37321700 \\
$\mathrm{C}$ & 6.21922479 & 2.87826010 & -0.37013600 \\
$\mathrm{C}$ & 5.60082479 & 0.91135410 & 0.90714800 \\
$\mathrm{C}$ & 7.48177479 & 2.32723210 & -0.59967000 \\
$\mathrm{H}$ & 5.95934679 & 3.85594010 & -0.76723000 \\
$\mathrm{C}$ & & & \\
$\mathrm{H}$ & 6.86823379 & 0.36912010 & 0.67771000 \\
$\mathrm{C}$ & 4.87232379 & 0.37300710 & 1.50738800 \\
$\mathrm{H}$ & 7.81278179 & 1.07078610 & -0.07855200 \\
$\mathrm{H}$ & & & \\
$\mathrm{H}$ & 8.21005679 & 2.88339210 & -1.18477500 \\
& & & \\
\hline & 7.11711879 & -0.60317790 & 1.09584500 \\
& & & -0.25401900
\end{tabular}

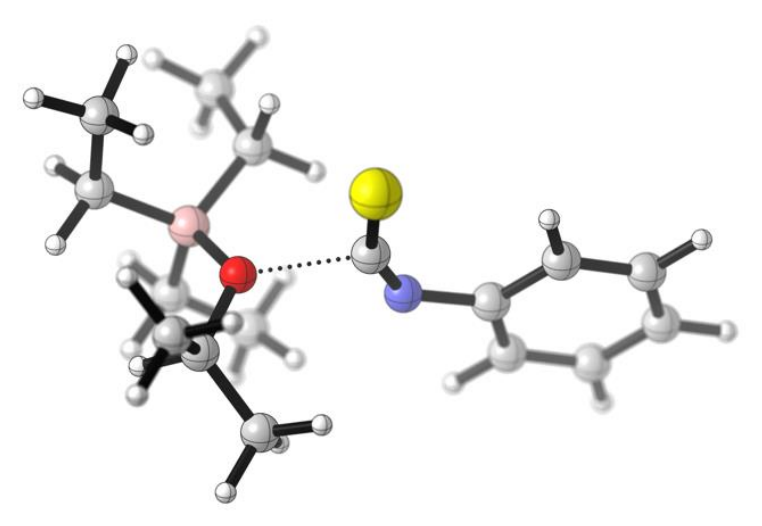

TS7

Imaginary frequency $=194.62 i \mathrm{~cm}^{-1}$
C
2.40156000
$-2.51171800$
1.23889700
$\mathrm{H}$
$1.66740600 \quad-3.17908900$
0.77463400 


\begin{tabular}{|c|c|c|c|}
\hline $\mathrm{H}$ & 3.24031200 & -2.39224000 & 0.54596200 \\
\hline $\mathrm{C}$ & 1.77352300 & -1.15341600 & 1.57063900 \\
\hline $\mathrm{H}$ & 2.54050500 & -0.54422600 & 2.06535500 \\
\hline $\mathrm{O}$ & 1.37834600 & -0.46171300 & 0.38983600 \\
\hline $\mathrm{C}$ & 0.61419300 & -1.31500700 & 2.55923100 \\
\hline $\mathrm{H}$ & -0.16743900 & -1.96922100 & 2.15497100 \\
\hline $\mathrm{H}$ & 0.98112500 & -1.76334800 & 3.49187100 \\
\hline $\mathrm{H}$ & 0.16015400 & -0.34772500 & 2.79535700 \\
\hline B & 2.10863800 & 0.87243300 & -0.01930100 \\
\hline $\mathrm{C}$ & 2.00806800 & 1.97277000 & 1.20670200 \\
\hline $\mathrm{H}$ & 2.45590800 & 1.56074400 & 2.12919800 \\
\hline $\mathrm{H}$ & 2.64857700 & 2.83725600 & 0.95542900 \\
\hline $\mathrm{C}$ & 3.69575100 & 0.50712000 & -0.29903400 \\
\hline $\mathrm{H}$ & 4.26770800 & 1.44399600 & -0.42343600 \\
\hline $\mathrm{H}$ & 4.13422600 & 0.03218600 & 0.59700400 \\
\hline $\mathrm{C}$ & 1.35935600 & 1.40183300 & -1.37994800 \\
\hline $\mathrm{H}$ & 1.36294900 & 0.61129300 & -2.14766800 \\
\hline $\mathrm{H}$ & 0.29554000 & 1.60283000 & -1.18322700 \\
\hline $\mathrm{C}$ & 3.97670800 & -0.39262700 & -1.51315300 \\
\hline $\mathrm{H}$ & 3.72299700 & 0.11538500 & -2.45378300 \\
\hline $\mathrm{H}$ & 5.03137000 & -0.70210700 & -1.58988100 \\
\hline $\mathrm{H}$ & 3.36916000 & -1.30581800 & -1.47306900 \\
\hline
\end{tabular}




\begin{tabular}{|c|c|c|c|}
\hline $\mathrm{C}$ & 0.60367200 & 2.49738800 & 1.54657500 \\
\hline $\mathrm{H}$ & 0.59140100 & 3.16971500 & 2.41965700 \\
\hline $\mathrm{H}$ & 0.17139400 & 3.05661400 & 0.70495100 \\
\hline $\mathrm{H}$ & -0.08154200 & 1.66742500 & 1.75361300 \\
\hline $\mathrm{C}$ & 1.97835600 & 2.67163500 & -1.99035000 \\
\hline $\mathrm{H}$ & 1.45899600 & 3.00358100 & -2.90304500 \\
\hline $\mathrm{H}$ & 1.95010200 & 3.51227600 & -1.28278600 \\
\hline $\mathrm{H}$ & 3.03294900 & 2.51955100 & -2.25910900 \\
\hline $\mathrm{H}$ & 2.77543700 & -2.99191400 & 2.15358500 \\
\hline $\mathrm{C}$ & -0.44467700 & -0.99265400 & -0.40975800 \\
\hline $\mathrm{N}$ & -1.19561300 & -0.20675200 & 0.16329700 \\
\hline $\mathrm{S}$ & -0.12135000 & -2.20426600 & -1.44428900 \\
\hline $\mathrm{C}$ & -2.57601100 & -0.01397100 & 0.02142800 \\
\hline $\mathrm{C}$ & -3.18372900 & 0.94046700 & 0.85540800 \\
\hline $\mathrm{C}$ & -3.36097200 & -0.72051300 & -0.90809900 \\
\hline $\mathrm{C}$ & -4.55446400 & 1.18278300 & 0.76360700 \\
\hline $\mathrm{H}$ & -2.56756500 & 1.48224200 & 1.56677200 \\
\hline $\mathrm{C}$ & -4.73179800 & -0.46909200 & -0.99388700 \\
\hline $\mathrm{H}$ & -2.89553600 & -1.45664700 & -1.55522800 \\
\hline $\mathrm{C}$ & -5.33593500 & 0.47996100 & -0.16140000 \\
\hline $\mathrm{H}$ & -5.01301500 & 1.92301300 & 1.41447300 \\
\hline $\mathrm{H}$ & -5.33027400 & -1.01896500 & -1.71630000 \\
\hline
\end{tabular}




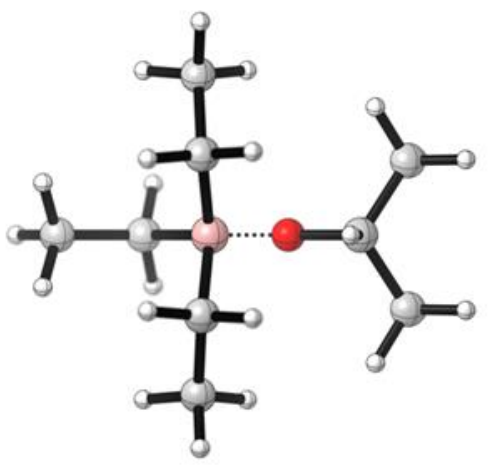

IN9

C

$2.78674700 \quad 1.26180600 \quad-0.27440100$

$\mathrm{H}$

$\begin{array}{lll}2.98679100 & 1.31197900 & -1.35388900\end{array}$

$\mathrm{H}$

$2.23076500 \quad 2.16234200 \quad 0.00892300$

$\mathrm{C}$

$\begin{array}{lll}1.97575100 & -0.00051800 & 0.05280600\end{array}$

$\mathrm{H}$

$\begin{array}{lll}1.79236500 & -0.00222200 & 1.14072700\end{array}$

$\mathrm{O}$

$\begin{array}{lll}0.76183300 & -0.00078700 & -0.65278000\end{array}$

C

$2.78894400 \quad-1.26049200 \quad-0.27793700$

$\mathrm{H}$

$2.98938800 \quad-1.30717000 \quad-1.35750700$

$\mathrm{H}$

$3.75247000 \quad-1.27018600 \quad 0.25121700$

$\mathrm{H}$

$\begin{array}{lll}2.23429500 & -2.16273600 & 0.00258500\end{array}$

B

$\begin{array}{lll}-0.57074700 & -0.00016400 & 0.09657900\end{array}$

C

$\begin{array}{lll}-0.69998300 & -1.34929100 & 1.05691400\end{array}$

$\mathrm{H}$

$\begin{array}{lll}0.14956700 & -1.38363800 & 1.76459500\end{array}$

$\mathrm{H}$

$\begin{array}{lll}-1.59366000 & -1.26651100 & 1.70271900\end{array}$

C

$\begin{array}{lll}-0.69921500 & 1.34957700 & 1.05609300\end{array}$

$\mathrm{H}$

$\begin{array}{lll}-1.59221200 & 1.26702400 & 1.70288300\end{array}$ 


\begin{tabular}{|c|c|c|c|}
\hline $\mathrm{H}$ & 0.15105600 & 1.38447400 & 1.76287700 \\
\hline $\mathrm{C}$ & -1.70793800 & -0.00024100 & -1.09597900 \\
\hline $\mathrm{H}$ & -1.55139300 & 0.87475700 & -1.75202400 \\
\hline $\mathrm{H}$ & -1.55156300 & -0.87545600 & -1.75176900 \\
\hline $\mathrm{C}$ & -0.76783100 & 2.69740200 & 0.31717300 \\
\hline $\mathrm{H}$ & -1.69732500 & 2.78767800 & -0.26239500 \\
\hline $\mathrm{H}$ & -0.72536600 & 3.56969000 & 0.98987600 \\
\hline $\mathrm{H}$ & 0.06023300 & 2.79636100 & -0.39747200 \\
\hline $\mathrm{C}$ & -0.76750700 & -2.69756300 & 0.31870300 \\
\hline $\mathrm{H}$ & -0.72591300 & -3.56946300 & 0.99196500 \\
\hline $\mathrm{H}$ & -1.69617400 & -2.78824600 & -0.26212400 \\
\hline $\mathrm{H}$ & 0.06157500 & -2.79684600 & -0.39471500 \\
\hline $\mathrm{C}$ & -3.17224500 & -0.00004800 & -0.62545100 \\
\hline $\mathrm{H}$ & -3.89769000 & 0.00005700 & -1.45494800 \\
\hline $\mathrm{H}$ & -3.39455300 & -0.88156400 & -0.00713100 \\
\hline $\mathrm{H}$ & -3.39433100 & 0.88149500 & -0.00709100 \\
\hline $\mathrm{H}$ & 3.75040300 & 1.27151200 & 0.25452000 \\
\hline
\end{tabular}

TS8

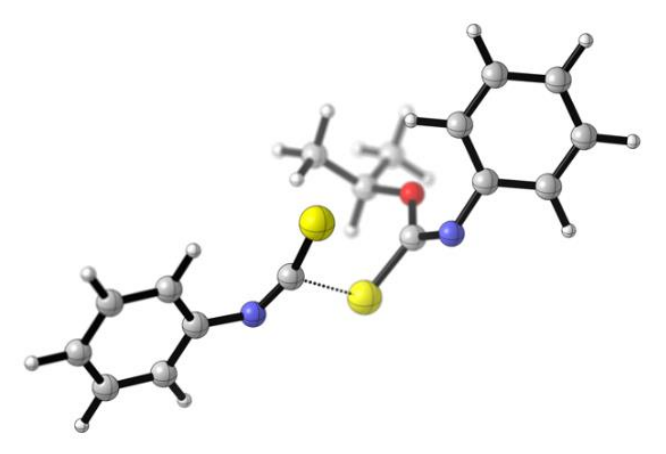


Imaginary frequency $=165.03 i \mathrm{~cm}^{-1}$

\begin{tabular}{|c|c|c|c|}
\hline $\mathrm{C}$ & 1.47579900 & 2.67954400 & 0.58195900 \\
\hline $\mathrm{H}$ & 0.79551200 & 3.12988600 & -0.14542100 \\
\hline $\mathrm{C}$ & 2.59008500 & 3.65386400 & 0.93274700 \\
\hline $\mathrm{H}$ & 3.30327900 & 3.19798800 & 1.63050100 \\
\hline $\mathrm{H}$ & 3.13294300 & 3.96520900 & 0.03297500 \\
\hline $\mathrm{H}$ & 2.16591000 & 4.54661100 & 1.40711400 \\
\hline $\mathrm{C}$ & 0.69327800 & 2.20404300 & 1.79929600 \\
\hline $\mathrm{H}$ & 0.19628800 & 3.05624200 & 2.27914700 \\
\hline $\mathrm{H}$ & -0.07215400 & 1.47756800 & 1.51002200 \\
\hline $\mathrm{H}$ & 1.36359100 & 1.73731000 & 2.53142700 \\
\hline $\mathrm{O}$ & 2.12771900 & 1.54791700 & -0.05331900 \\
\hline $\mathrm{C}$ & 1.48071000 & 0.70101000 & -0.90596700 \\
\hline $\mathrm{N}$ & 2.06952400 & -0.40829900 & -1.22047000 \\
\hline $\mathrm{S}$ & -0.08246300 & 1.11608200 & -1.57378500 \\
\hline $\mathrm{C}$ & 3.23051200 & -0.84600300 & -0.56171800 \\
\hline $\mathrm{C}$ & 4.34667300 & -1.22236400 & -1.33231600 \\
\hline $\mathrm{C}$ & 3.28644000 & -1.03900900 & 0.83434800 \\
\hline $\mathrm{C}$ & 5.49134800 & -1.74859000 & -0.72684200 \\
\hline $\mathrm{H}$ & 4.30386400 & -1.09440700 & -2.41136300 \\
\hline $\mathrm{C}$ & 4.42651500 & -1.57656800 & 1.43263000 \\
\hline $\mathrm{H}$ & 2.42594900 & -0.76975300 & 1.43828000 \\
\hline
\end{tabular}




\begin{tabular}{|c|c|c|c|}
\hline $\mathrm{C}$ & 5.54043200 & -1.93050400 & 0.65945500 \\
\hline $\mathrm{H}$ & 6.34442800 & -2.02358700 & -1.34323900 \\
\hline $\mathrm{H}$ & 4.44569700 & -1.72085300 & 2.51084300 \\
\hline $\mathrm{H}$ & 6.42712400 & -2.34784300 & 1.12979400 \\
\hline $\mathrm{C}$ & -1.61571700 & -0.42193400 & -0.31206400 \\
\hline $\mathrm{N}$ & -2.68026600 & 0.11449900 & -0.64912700 \\
\hline $\mathrm{C}$ & -3.98648300 & -0.20569000 & -0.23200900 \\
\hline $\mathrm{C}$ & -5.04356300 & 0.48254300 & -0.85141800 \\
\hline $\mathrm{C}$ & -4.27057400 & -1.15595900 & 0.76521000 \\
\hline $\mathrm{C}$ & -6.36411000 & 0.22056400 & -0.48532400 \\
\hline $\mathrm{H}$ & -4.81192600 & 1.21698900 & -1.61785500 \\
\hline $\mathrm{C}$ & -5.59546500 & -1.40815300 & 1.12791700 \\
\hline $\mathrm{H}$ & -3.46020100 & -1.68881500 & 1.25118400 \\
\hline $\mathrm{C}$ & -6.64750100 & -0.72592400 & 0.50659900 \\
\hline $\mathrm{H}$ & -7.17296700 & 0.75756900 & -0.97433800 \\
\hline $\mathrm{H}$ & -5.80459100 & -2.14356400 & 1.90104000 \\
\hline $\mathrm{H}$ & -7.67617100 & -0.92837500 & 0.79287600 \\
\hline $\mathrm{S}$ & -0.72275000 & -1.53234100 & 0.46101800 \\
\hline
\end{tabular}

TS9 


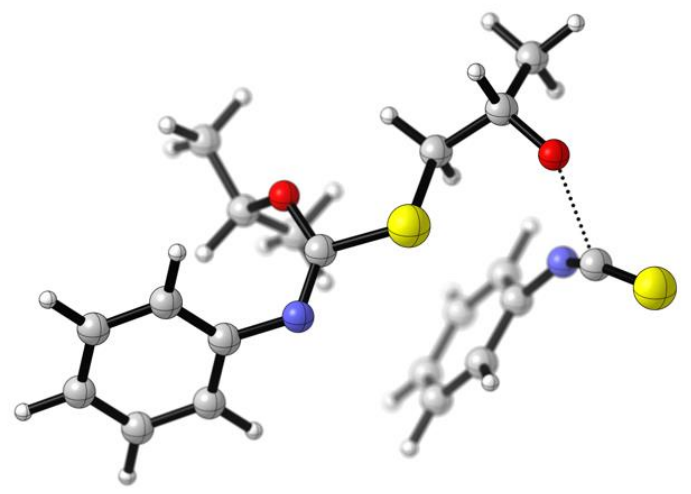

Imaginary frequency $=157.88 i \mathrm{~cm}^{-1}$

\begin{tabular}{|c|c|c|c|}
\hline $\mathrm{C}$ & 1.42550100 & -1.69294100 & 0.74632000 \\
\hline $\mathrm{H}$ & 1.63829100 & -0.71350800 & 1.18173500 \\
\hline $\mathrm{C}$ & 2.73325500 & -2.47988200 & 0.46615600 \\
\hline $\mathrm{H}$ & 2.40270800 & -3.54110000 & 0.30820600 \\
\hline $\mathrm{O}$ & 3.42392000 & -2.01135400 & -0.61419000 \\
\hline $\mathrm{C}$ & 3.56013000 & -2.47982500 & 1.77605100 \\
\hline $\mathrm{H}$ & 3.89012800 & -1.45825800 & 2.00951400 \\
\hline $\mathrm{H}$ & 2.99498600 & -2.86965900 & 2.63730700 \\
\hline $\mathrm{H}$ & 4.45479100 & -3.10186400 & 1.64287200 \\
\hline $\mathrm{H}$ & 0.75315900 & -2.24083900 & 1.41000500 \\
\hline $\mathrm{C}$ & 3.75972400 & 0.33019000 & -1.05042500 \\
\hline $\mathrm{N}$ & 3.25337800 & 0.85538200 & -0.08787900 \\
\hline $\mathrm{S}$ & 4.61728700 & 0.11336300 & -2.39233600 \\
\hline $\mathrm{C}$ & 2.30424900 & 1.78248900 & 0.29918200 \\
\hline $\mathrm{C}$ & 2.26153900 & 2.20233200 & 1.63887400 \\
\hline $\mathrm{C}$ & 1.37437300 & 2.29302200 & -0.62666800 \\
\hline
\end{tabular}




\begin{tabular}{|c|c|c|c|}
\hline $\mathrm{C}$ & 1.31290400 & 3.14407500 & 2.04055400 \\
\hline $\mathrm{H}$ & 2.97515800 & 1.78987400 & 2.34610400 \\
\hline $\mathrm{C}$ & 0.42973900 & 3.22964500 & -0.20988300 \\
\hline $\mathrm{H}$ & 1.39855300 & 1.94380300 & -1.65395400 \\
\hline $\mathrm{C}$ & 0.39502100 & 3.66341700 & 1.12133500 \\
\hline $\mathrm{H}$ & 1.28795300 & 3.46727000 & 3.07803000 \\
\hline $\mathrm{H}$ & -0.28588700 & 3.61912700 & -0.92944700 \\
\hline $\mathrm{H}$ & -0.34678100 & 4.39062000 & 1.44001600 \\
\hline $\mathrm{S}$ & 0.57876600 & -1.41779400 & -0.86313000 \\
\hline $\mathrm{C}$ & -1.06845200 & -0.97282700 & -0.37808300 \\
\hline $\mathrm{N}$ & -1.75065800 & -0.26755200 & -1.20669200 \\
\hline $\mathrm{C}$ & -3.14563700 & -0.11494600 & -1.14254700 \\
\hline $\mathrm{C}$ & -3.69492000 & 1.17659400 & -1.22250800 \\
\hline $\mathrm{C}$ & -4.01354100 & -1.22309400 & -1.09922800 \\
\hline $\mathrm{C}$ & -5.07948000 & 1.35763100 & -1.21839800 \\
\hline $\mathrm{H}$ & -3.02396700 & 2.02999700 & -1.27379800 \\
\hline $\mathrm{C}$ & -5.39663600 & -1.03483100 & -1.10694100 \\
\hline $\mathrm{H}$ & -3.59601800 & -2.22531100 & -1.05703000 \\
\hline $\mathrm{C}$ & -5.93944600 & 0.25476700 & -1.15913100 \\
\hline $\mathrm{H}$ & -5.48742400 & 2.36445300 & -1.26761300 \\
\hline $\mathrm{H}$ & -6.05338500 & -1.90097100 & -1.07171500 \\
\hline $\mathrm{H}$ & -7.01682600 & 0.39740400 & -1.16234600 \\
\hline
\end{tabular}




$\begin{array}{llll}\mathrm{O} & -1.46564700 & -1.48223900 & 0.81053000 \\ \mathrm{C} & -2.24283800 & -0.65913000 & 1.75016200 \\ \mathrm{H} & -3.13582900 & -0.29845900 & 1.23776300 \\ \mathrm{C} & -2.64173100 & -1.60476600 & 2.86801400 \\ \mathrm{H} & -3.23524100 & -2.43960100 & 2.47900200 \\ \mathrm{H} & -1.75568700 & -2.00662100 & 3.37353400 \\ \mathrm{H} & -3.24678200 & -1.06451700 & 3.60499200 \\ \mathrm{C} & -1.39509500 & 0.51455200 & 2.21357900 \\ \mathrm{H} & -1.08037900 & 1.13467300 & 1.36916800 \\ \mathrm{H} & -1.98241700 & 1.14383100 & 2.89268100 \\ \mathrm{H} & -0.50311400 & 0.16567000 & 2.74521000\end{array}$

\section{PO-Et ${ }_{3} B$}

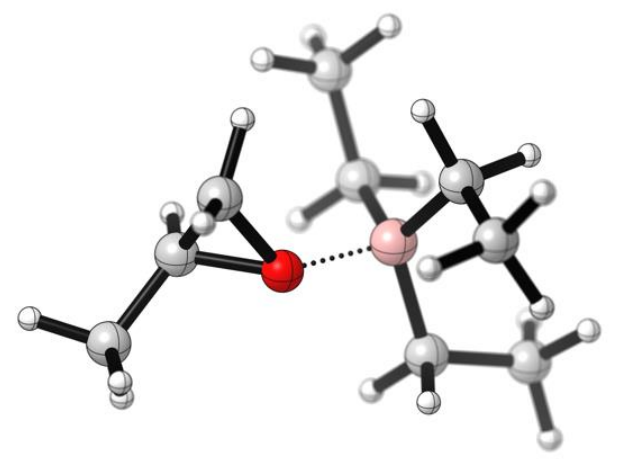

$\begin{array}{llll}\mathrm{C} & -1.89160700 & -0.22708400 & 1.17105700 \\ \mathrm{C} & -2.24144400 & -0.04007300 & -0.24215400 \\ \mathrm{O} & -0.92631100 & -0.58022000 & 0.13394900 \\ \mathrm{H} & -1.60587700 & 0.62812300 & 1.77479100 \\ \mathrm{H} & -2.26435700 & -1.09565700 & 1.70890900 \\ \mathrm{H} & -2.16849400 & 0.97075200 & -0.63367400\end{array}$




\begin{tabular}{|c|c|c|c|}
\hline $\mathrm{C}$ & -3.12578500 & -0.98813600 & -0.99613300 \\
\hline $\mathrm{H}$ & -4.15605400 & -0.61140100 & -0.97954800 \\
\hline $\mathrm{H}$ & -2.80720200 & -1.06159700 & -2.04222200 \\
\hline $\mathrm{H}$ & -3.11025900 & -1.98624100 & -0.54635900 \\
\hline $\mathrm{B}$ & 0.69210900 & 0.17954400 & -0.12189300 \\
\hline $\mathrm{C}$ & 0.44790200 & 1.68365700 & -0.66084700 \\
\hline $\mathrm{H}$ & 1.42000000 & 1.99924800 & -1.07789800 \\
\hline $\mathrm{H}$ & -0.22836300 & 1.67409900 & -1.53213000 \\
\hline $\mathrm{C}$ & 1.34442900 & 0.04580700 & 1.34742400 \\
\hline $\mathrm{H}$ & 2.31918200 & 0.56297300 & 1.31276300 \\
\hline $\mathrm{H}$ & 0.75656200 & 0.61562200 & 2.08437100 \\
\hline $\mathrm{C}$ & 1.23631400 & -0.83759400 & -1.25604200 \\
\hline $\mathrm{H}$ & 1.09976200 & -1.88162400 & -0.93456400 \\
\hline $\mathrm{H}$ & 0.64394200 & -0.73165800 & -2.18106900 \\
\hline $\mathrm{C}$ & -0.01135900 & 2.77324300 & 0.32377800 \\
\hline $\mathrm{H}$ & -0.06417000 & 3.76287200 & -0.15294600 \\
\hline $\mathrm{H}$ & -1.00682300 & 2.56604400 & 0.73719600 \\
\hline $\mathrm{H}$ & 0.67717700 & 2.85980800 & 1.17413500 \\
\hline $\mathrm{C}$ & 1.56077600 & -1.37913900 & 1.88292500 \\
\hline $\mathrm{H}$ & 2.00252000 & -1.38402600 & 2.89007600 \\
\hline $\mathrm{H}$ & 0.61320600 & -1.93154300 & 1.94052100 \\
\hline $\mathrm{H}$ & 2.22909700 & -1.95703800 & 1.23173300 \\
\hline
\end{tabular}




$\begin{array}{llll}\mathrm{C} & 2.72300100 & -0.62396500 & -1.59939500 \\ \mathrm{H} & 3.07727100 & -1.32284000 & -2.37081100 \\ \mathrm{H} & 2.90867100 & 0.39205800 & -1.97278000 \\ \mathrm{H} & 3.36078400 & -0.76422300 & -0.71630100\end{array}$

PhITC-Et 3 B through the nitrogen atom

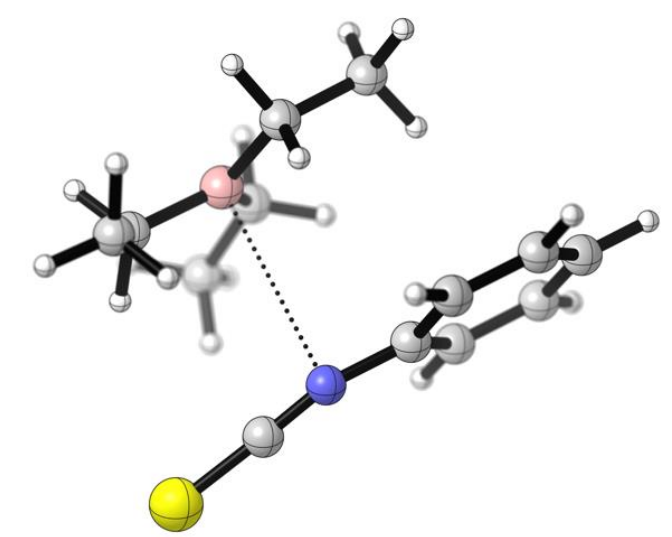

\begin{tabular}{|c|c|c|c|}
\hline $\mathrm{C}$ & -3.82829200 & 0.66309500 & -0.09984400 \\
\hline $\mathrm{C}$ & -3.25002100 & 0.61100400 & 1.17295500 \\
\hline $\mathrm{C}$ & -1.89092900 & 0.87431700 & 1.34134000 \\
\hline $\mathrm{C}$ & -1.11305900 & 1.19817400 & 0.22116300 \\
\hline $\mathrm{C}$ & -1.68077800 & 1.24926400 & -1.06182100 \\
\hline $\mathrm{C}$ & -3.04091500 & 0.98128800 & -1.21240000 \\
\hline $\mathrm{H}$ & -4.88680000 & 0.45315700 & -0.22541400 \\
\hline $\mathrm{H}$ & -3.85623500 & 0.35990500 & 2.03877800 \\
\hline $\mathrm{H}$ & -1.42639200 & 0.83343800 & 2.32122600 \\
\hline $\mathrm{H}$ & -1.05702600 & 1.49535200 & -1.91517400 \\
\hline $\mathrm{H}$ & -3.48493400 & 1.01941800 & -2.20328000 \\
\hline $\mathrm{N}$ & 0.23267600 & 1.46282800 & 0.38860900 \\
\hline
\end{tabular}




\begin{tabular}{|c|c|c|c|}
\hline $\mathrm{C}$ & 1.32140600 & 1.89708200 & 0.20720100 \\
\hline S & 2.81060700 & 2.45483800 & 0.04896900 \\
\hline B & 0.89607000 & -1.80981000 & -0.12795900 \\
\hline $\mathrm{C}$ & -0.23336700 & -2.35648300 & 0.83598700 \\
\hline $\mathrm{H}$ & 0.18705200 & -3.23569800 & 1.35614200 \\
\hline $\mathrm{H}$ & -0.36553800 & -1.61796900 & 1.64346500 \\
\hline $\mathrm{C}$ & 0.61949200 & -1.69393200 & -1.68024000 \\
\hline $\mathrm{H}$ & -0.36614500 & -1.22649800 & -1.82799200 \\
\hline $\mathrm{H}$ & 0.46804700 & -2.73240100 & -2.02984800 \\
\hline $\mathrm{C}$ & 2.32682600 & -1.48260000 & 0.45890700 \\
\hline $\mathrm{H}$ & 2.94816000 & -2.34631000 & 0.15053400 \\
\hline $\mathrm{H}$ & 2.77533700 & -0.63294100 & -0.07387000 \\
\hline $\mathrm{C}$ & -1.59912500 & -2.71526900 & 0.23543200 \\
\hline $\mathrm{H}$ & -1.50858800 & -3.50490500 & -0.52189200 \\
\hline $\mathrm{H}$ & -2.30075800 & -3.07381500 & 1.00081500 \\
\hline $\mathrm{H}$ & -2.06142700 & -1.84889300 & -0.25094100 \\
\hline $\mathrm{C}$ & 1.66281100 & -1.00129700 & -2.56714100 \\
\hline $\mathrm{H}$ & 1.37023600 & -1.01221900 & -3.62596800 \\
\hline $\mathrm{H}$ & 1.79849800 & 0.04799300 & -2.27588600 \\
\hline $\mathrm{H}$ & 2.64396400 & -1.48719200 & -2.49276600 \\
\hline $\mathrm{C}$ & 2.46429200 & -1.27552700 & 1.97414700 \\
\hline $\mathrm{H}$ & 1.87441600 & -0.41228500 & 2.30888500 \\
\hline
\end{tabular}



$\mathrm{H}$
$2.11255600 \quad-2.14868100$
2.53757700
$\mathrm{H}$
$\begin{array}{lll}3.50673800 & -1.09229900 & 2.26752800\end{array}$

PhITC-Et ${ }_{3} B$ through the sulfur atom

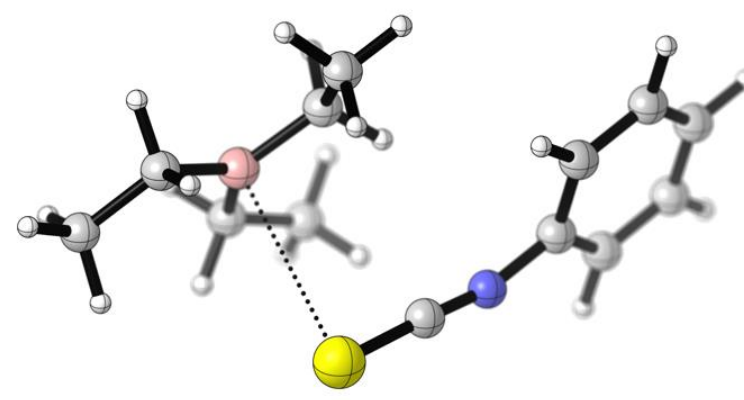
$\mathrm{C}$
4.63827300
0.88740300
$-0.17677600$
C
3.74265600
1.21853900
0.84708500
C
2.56746400
0.48891500
1.02091300
C
2.29467400
$-0.58325900$
0.15518200
C
3.18498600
$-0.92427500$
$-0.87294800$
C
4.35596500
$-0.18279100$
$-1.03266500$
$\mathrm{H}$
$\begin{array}{lll}5.55157200 & 1.46121000 & -0.30660000\end{array}$
$\mathrm{H}$
$3.95764000 \quad 2.04941500 \quad 1.51337500$
$\mathrm{H}$
1.86201400
0.73585100
1.80736800
$\mathrm{H}$
2.95027000
$-1.75577000$
$-1.53011000$
$\mathrm{H}$
$\begin{array}{lll}5.04782000 & -0.44243700 & -1.82898300\end{array}$
$\mathrm{N}$
$\begin{array}{lll}1.12996200 & -1.30930600 & 0.30683000\end{array}$
C
$0.06702500-1.64416500$
0.71293900
S
$\begin{array}{lll}-1.36792700 & -2.16108600 & 1.18859400\end{array}$
B
$-2.34217000$
0.85481100
$-0.45701300$ 


\begin{tabular}{|c|c|c|c|}
\hline $\mathrm{C}$ & -2.37709100 & 0.13165500 & -1.86409800 \\
\hline $\mathrm{H}$ & -3.09548000 & 0.71338200 & -2.47204200 \\
\hline $\mathrm{H}$ & -2.86719600 & -0.84795200 & -1.75130400 \\
\hline $\mathrm{C}$ & -1.04834000 & 1.64483500 & -0.00472300 \\
\hline $\mathrm{H}$ & -1.02145500 & 2.52284300 & -0.67932700 \\
\hline $\mathrm{H}$ & -0.14516300 & 1.08281700 & -0.27797000 \\
\hline $\mathrm{C}$ & -3.64988300 & 0.92178900 & 0.43265300 \\
\hline $\mathrm{H}$ & -3.91284700 & 1.99385000 & 0.49948200 \\
\hline $\mathrm{H}$ & -3.38358300 & 0.65562900 & 1.46791500 \\
\hline $\mathrm{C}$ & -0.94754200 & 2.12455600 & 1.44984300 \\
\hline $\mathrm{H}$ & -0.93778400 & 1.27748500 & 2.14778100 \\
\hline $\mathrm{H}$ & -0.03230700 & 2.70544900 & 1.62558300 \\
\hline $\mathrm{H}$ & -1.79742800 & 2.76144700 & 1.72530400 \\
\hline $\mathrm{C}$ & -4.88326000 & 0.12140500 & -0.00858100 \\
\hline $\mathrm{H}$ & -4.67385700 & -0.95591800 & -0.03130900 \\
\hline $\mathrm{H}$ & -5.73348000 & 0.27493600 & 0.66991500 \\
\hline $\mathrm{H}$ & -5.21166900 & 0.40903200 & -1.01560900 \\
\hline $\mathrm{C}$ & -1.06407600 & -0.03014700 & -2.64318000 \\
\hline $\mathrm{H}$ & -1.22604900 & -0.50351400 & -3.62119300 \\
\hline $\mathrm{H}$ & -0.57919900 & 0.93764700 & -2.82385000 \\
\hline $\mathrm{H}$ & -0.34898200 & -0.65370200 & -2.09254700 \\
\hline
\end{tabular}

